\title{
KURA MARIE TEIRA TAYLOR
}

\author{
TE ATIAWA PAAKE
}

\section{REFLECTIONS ON THE PLAYGROUNDS OF MY LIFE}

\section{Kura Marie Teira Taylor}

A thesis submitted in fulfilment of the requirements for the Degree of Doctor of Philosophy Stout Research Centre for New Zealand Studies

Faculty of Humanities and Social Sciences

Victoria University of Wellington, 2018 


\section{DEDICATION}

This thesis is dedicated to:

My parents,

the late Mouti Erueti Mira Teira Taylor and the late Gracey Nora Skelton Taylor

My son Adrian Taylor and wife Susan (nee Darney)

My three mokopuna, grandsons:

the late Michael Mouti Taylor, B Phys Ed, B Physio (partial), Otago

(1 December 1988 - 17 June 2013)

Moe moe ra taku mokopuna ataahua

John Erueti Taylor, B Sc (Geology), Otago

and

Anthony Adrian Taylor,

Building and Construction, New Plymouth

Ma te wa, taku mokopuna,

Kia kaha, kia manawanui, kia tau te rangimarie. 


\begin{abstract}
This thesis is about constructing an indigenous autobiographical narrative of my life as an Aotearoa/New Zealand Te Atiawa Iwi Paake, adult, Maori woman teacher, claiming Maori/Pakeha identity.

Three Maori theoretical approaches underpin the thesis: Kaupapa Maori; Mana Wahine, Maori Feminism; and Aitanga. Kaupapa Maori takes for granted being Maori; Maori language, te reo Maori; and tikanga, Maori cultural practices. Whakapapa, Maori descent lines and Pakeha genealogy connect with Maori/Pakeha identity. Mana Wahine, Maori Feminism, is about how Maori women live their lives and view their worlds. Aitanga relates to the distribution of power and Maori as active participants in social relationships.
\end{abstract}

Eight decades of problematic, complex, multi-layered, multi-sited, multi-faceted life experiences of one Maori woman teacher are explored. Memories and events are presented through a metaphor of 'play' in a socially constructed milieu of power relationships, language and dialogic encounters reflected upon and analysed. Three main recurring themes of Whakapapa and Identity, Cultural Navigation and Cultural Flexibility, Resilience and Endurance, are woven into the thesis fabric. 


\section{ACKNOWLEDGEMENTS}

Nga Mate, those who have passed on and who deserve particular mention for the wonderful memories that I treasure:

My first grandson Michael Mouti Taylor (1 December 1988 - 17 June 2013), Te Atiawa iwi, Ngati Rahiri and Puketapu hapu, Bachelor of Physical Education, Bachelor of Physiotherapy (Partial) Otago, budding Physiotherapist, whose early years I was very fortunate to share. As a young man Michael later monitored my post-surgery exercise and swim programmes with the energy, wit, humour and exuberance of youth. He also wrote me proper letters about his university studies, student life style, sporting developments, future possibilities and news of family.

My nephew, Peter Errol Karipi Ngatai, Te Atiawa and Ngati Mutunga Iwi, who designed my personal moko kauwae, woman's chin tattoo, adorning the spine of my Master's thesis. Peter also carved 'Tokotoko', my personal walking/talking stick, depicting his interpretation of my achievements along the pathways of my life.

My very dear friend Ramai Hayward, for her inspiring telephone calls and notes of encouragement, but more importantly for unexpectedly producing, in the form of an old sepia photograph, the painting of my father's whangai parent, foster mother, Harimate Epiha: 'for all your achievements that have never been acknowledged dear' ${ }^{1}$

My wonderful friend Joy Rakena, whom I met at Christchurch Teachers' Training College, who shared her family with me, kept my feet on the ground, talked much common sense when I needed it and regularly visited my mother.

My precious aunt, Ngapera Taupiri Teira, Aunty Pera, my father's sister, who signed the application to the Maori Land Court to constitute the Ngahina Trust. The original Ngahina Trust families of Beneficial Owners and their descendants, who changed my retirement years in ways I had never ever envisaged.

\footnotetext{
${ }^{1}$ Ramai Hayward, personal communication, 1994.
} 
My cousins, the late Te Akerama Manuka Taiaki and his sister, the late Wharemawhai Mina TimuTimu, for contributions to historical information, tenor of meetings, and guidance for my Maori language presentations.

Paul Brunton, close friend and first Chartered Accountant for Ngahina Trust, who, under pressure of early Paraparaumu land sales, said, 'Now hang on a minute. What can we save for the owners?' Paul often commented on his interpretation of what he termed "historic dishonourable treatment' by Pakeha towards the Ngahina Trust Maori Beneficial Owners.

Bruce Mansell, Chairman Alpha Corporation, Coastlands Shopping Town Limited, Paraparaumu, and Ngahina Developments Limited, veteran of the Boardroom, who said, 'I don't know what is wrong with them, I don't have a problem with you.' I sat in meetings with Bruce for thirty years, always learning something new.

John McKenzie, NZEI, greeting me with, 'Happiness is Marie Taylor!'

The thirty close friends and relatives who passed away between June 2013 and November 2017, who also trod the highways and byways of life with me.

Moe moe ra koutou. Kia ora mo to mahi me nga korero. Moe moe ra. Moe moe ra. Inevitably over eighty years, there are many others who have touched my life, engaging in both positive and negative learning experiences, and to whom I would also like to register my heartfelt and unreserved thanks.

School Committees, teachers, parents and children at schools to which I was appointed, who participated in, and contributed to, the joy in learning that we shared throughout my forty years of growth as a teacher.

The New Zealand Educational Institute, in particular Helen Anderson and Joh Cogle, for their friendship and enlightening experiences that broadened my learning as an adult. Our discussions in the fields of meeting procedures, teacher politics, 
persistent questioning of government policies leading to educational change, and international travel to Switzerland were opportunities that contributed markedly to my growth. Most important are the management skills I learned and was able to transfer to the administration of the Ngahina Trust and the development of business relationships during my third age.

The Beneficial Owners of Ngahina Trust, some travelling long distances, who regularly participate in the decision-making processes and activities of the Trust. The Directors of Coastlands ShoppingTown and Ngahina Developments Limited, who continue to guide Ngahina Trust through land retention and development projects on our Maori ancestral land, located in Paraparaumu on the Kapiti Coast of New Zealand.

The women of the Arahina Branch Maori Women's Welfare League, Dominion Executive, Regional Council, and members I encountered in the course of my membership and while in office, for the Maori intangibles they brought to my life. The members of the New Zealand Teacher Registration Board and the Auckland College of Education Council, with whom I sat through many years of meetings.

My friends: Pam and Barry Darney, for information about early Waitara, copying of photographs and support; Natalie Horter (nee Rowe); Nan Lineham (nee Tamati); Betty Miege (nee Tate); Waiora Port; Joce Jesson; Maxine Stevenson; Terehia Brock; Gloria Culley; Jan Taylor; and Ellen Chan, for their encouragement and interest in my writing and general wellbeing.

My huānga, Dr Helène Connor, for her inspirational conversations, interactions and practical encouragement throughout the writing of this thesis.

My immediate family: Adrian and Susan, the late Michael Mouti, John and Anthony, of whom I am so inordinately proud; my parents, the late Mouti and Nora Taylor; my brothers, sisters and extended Maori/Pakeha relatives and families. 
My supervisors, Dr Kay Morris Matthews, who began this journey with me, Dr Richard Hill, and Dr Lydia Wevers, and also Dr Anne Else, who so ably supported, encouraged and advised me during this project.

Who and what I came from have gone a long way towards forming what I have become. My heartfelt thanks to all who have touched my life in so many different ways and participated in my forming. Every encounter has been a learning experience. 


\section{TABLE OF CONTENTS}

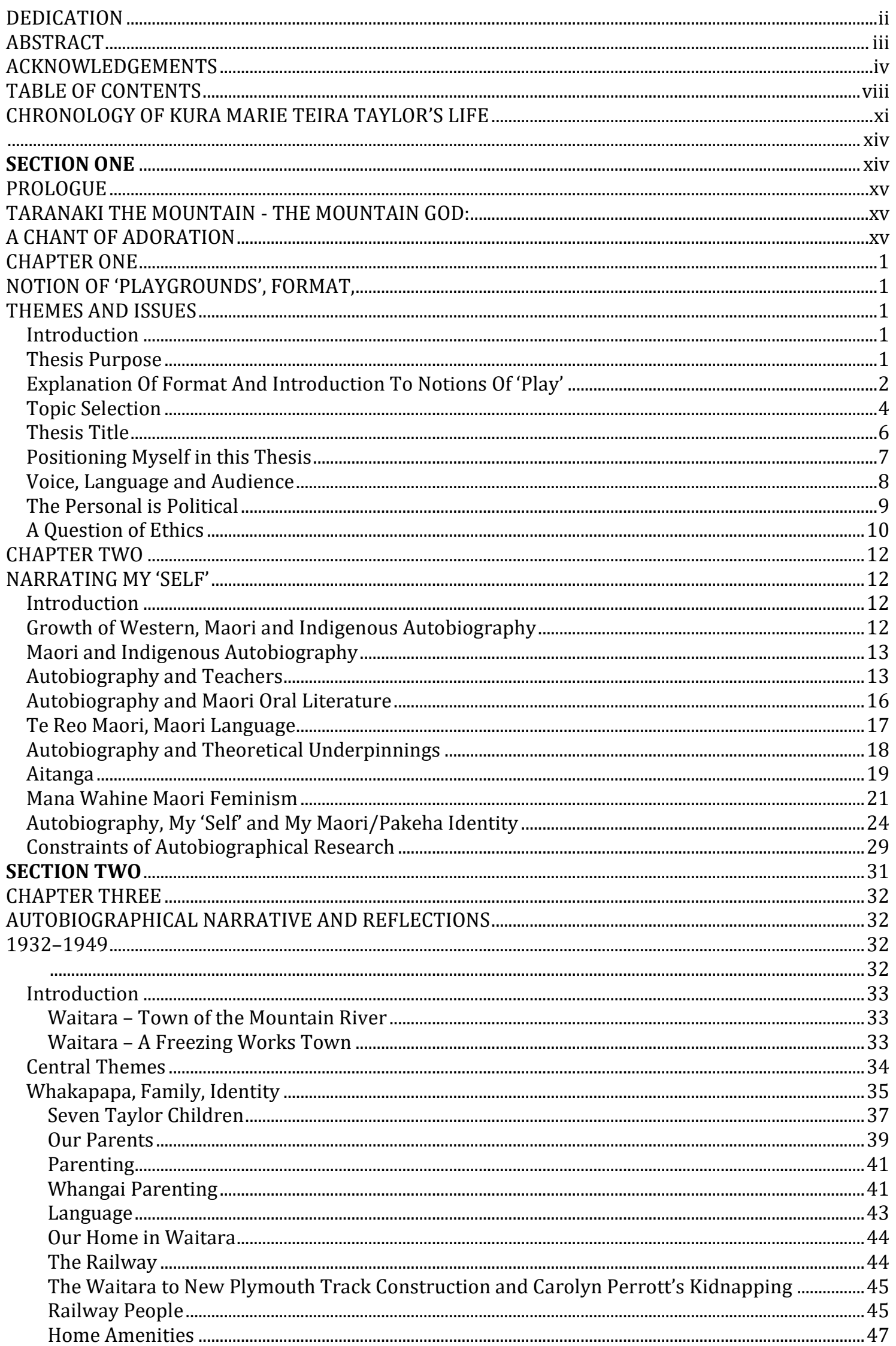




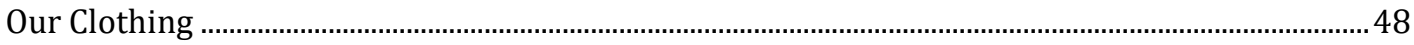

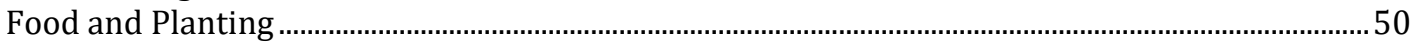

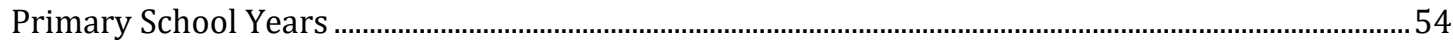

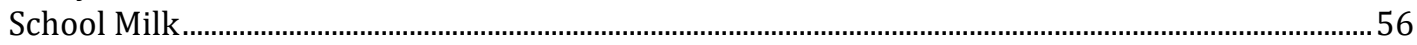

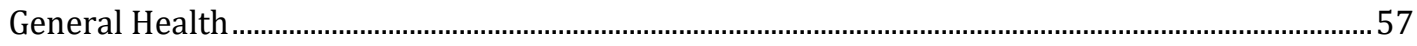

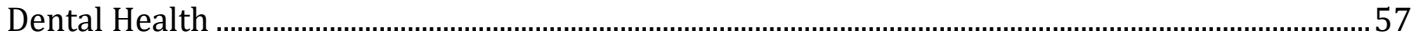

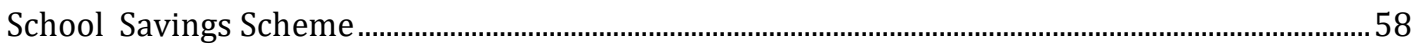

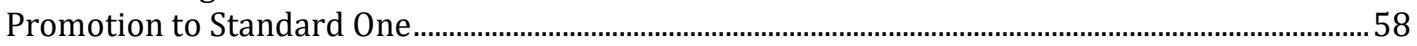

The Fancy Dress Ball ................................................................................................................................... 61

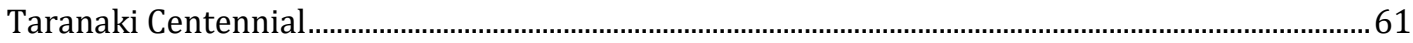

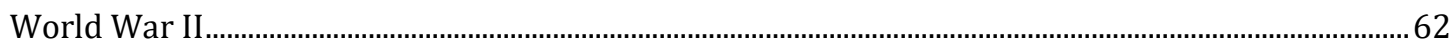

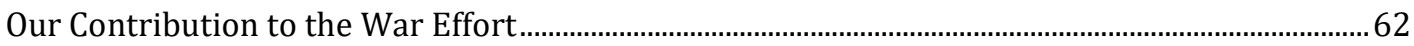

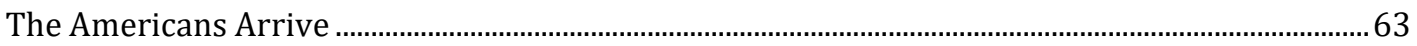

Blackouts and Community Singing ………………………………………………………………...6

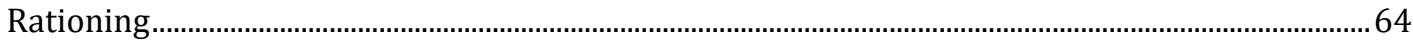

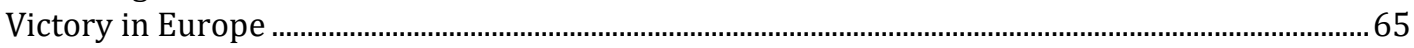

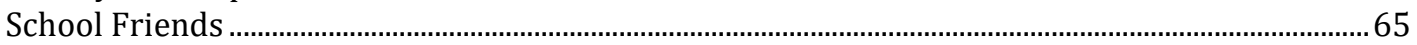

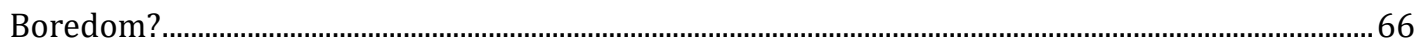

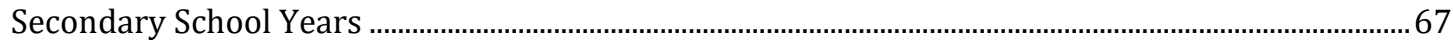

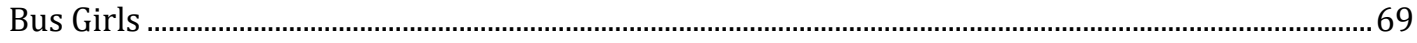

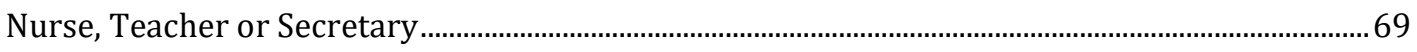

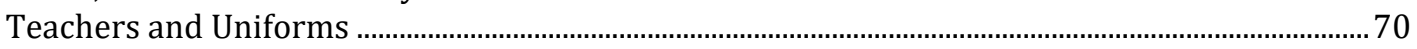

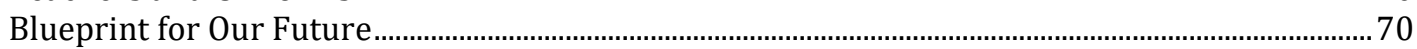

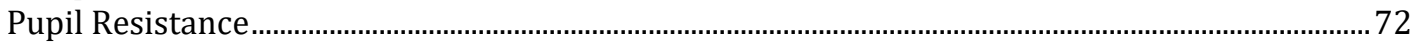

Poliomyelitis Epidemic And Afterwards.............................................................................................

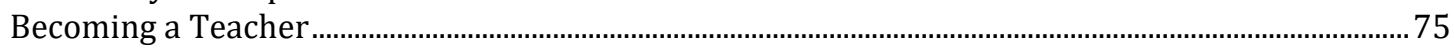

Concluding Comments ...................................................................................................................................

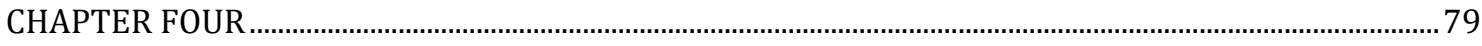

TEACHER TRAINING, TEACHING YEARS AND REFLECTIONS …………………………………………......79

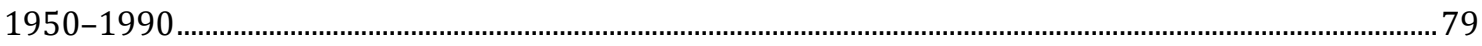

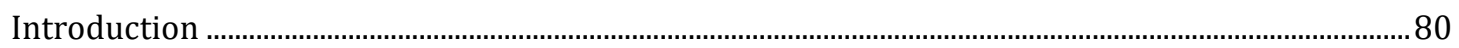

Aspects of Teacher Training and Teaching Experiences ………………………………....................... 81

Christchurch Teachers' Training College ( CTTC) ………………………………………………………... 82

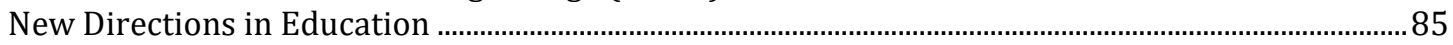

'Division A' Primary Teacher Training .....................................................................................................86

Friday Night Club Alternatives ...................................................................................................... 88

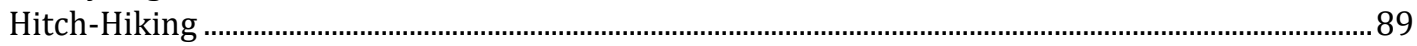

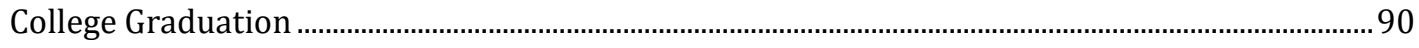

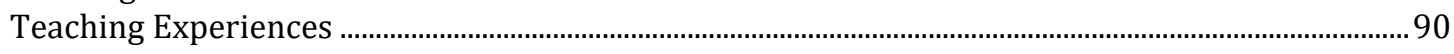

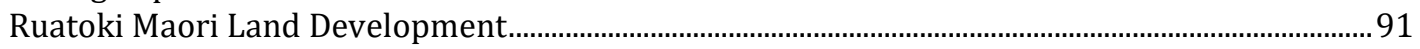

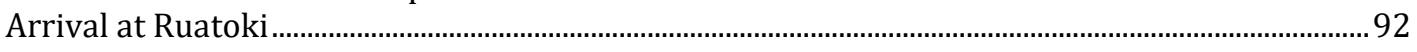

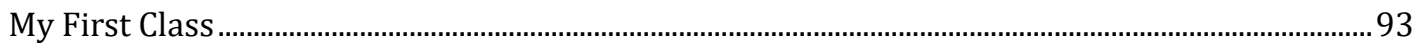

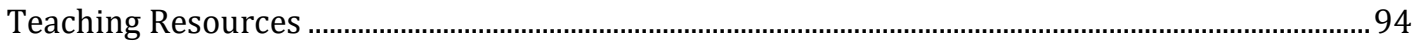

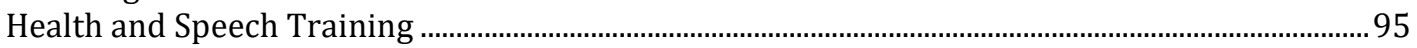

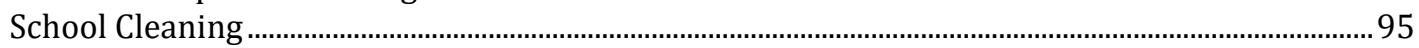

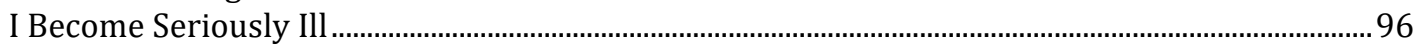

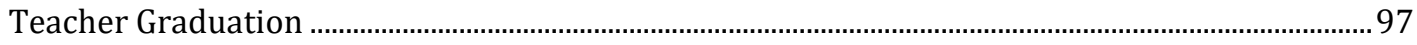

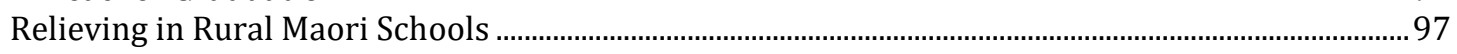

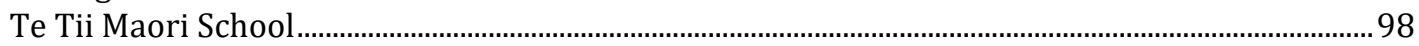

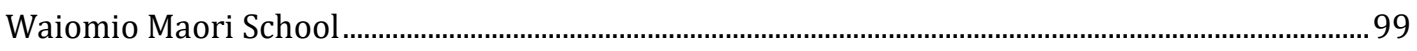

Rakaumanga Maori School......................................................................................................................... 99

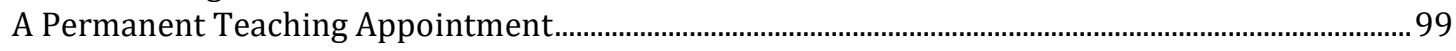

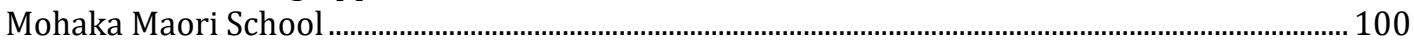

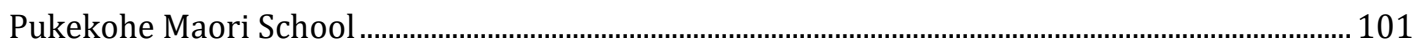

Permanent Senior Appointments to Education Board Schools .......................................................... 102

Ruawai District High School, Northland ............................................................................................. 103

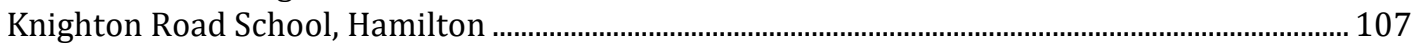

Urbanisation And The Hunn Report ................................................................................................ 107

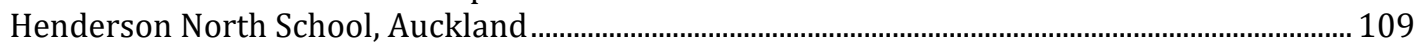




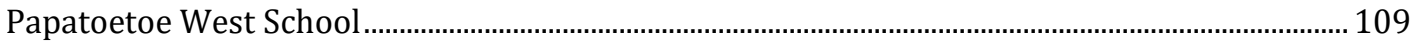

Cornwall Park Primary School 1969-1988 …........................................................................................ 110

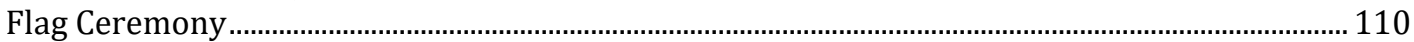

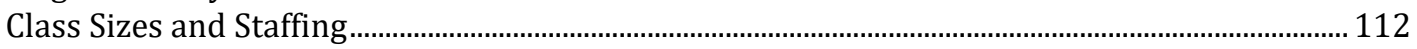

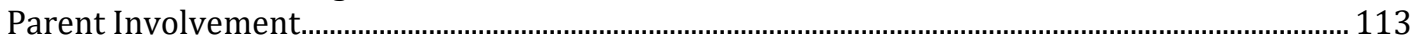

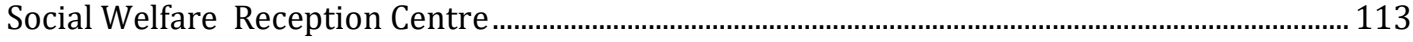

Refurbished Classrooms ..................................................................................................................................... 114

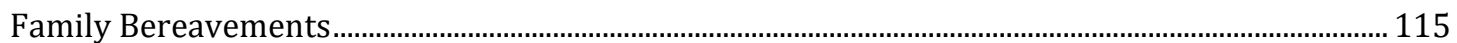

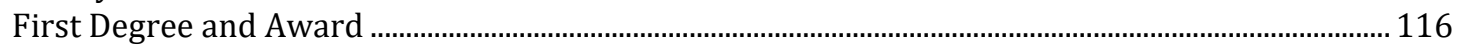

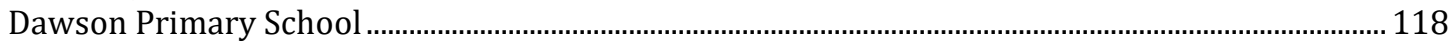

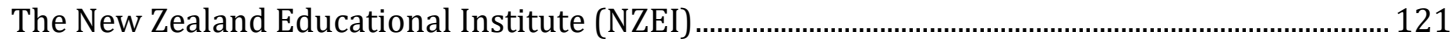

Auckland NZEI Centennial World Education Conference, 1975 ........................................................ 122

Te Tatai Hono, NZEI Report And Recommendations On Maori Education, 1981-1982 .................. 124

UNESCO/WCOTP Consultation, Morges, Switzerland, 1981 ............................................................... 125

Plenary Sessions ............................................................................................................................................ 128

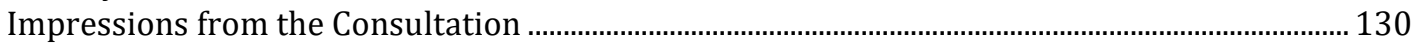

Ministerial Appointments .................................................................................................................................... 132

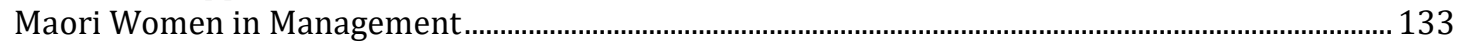

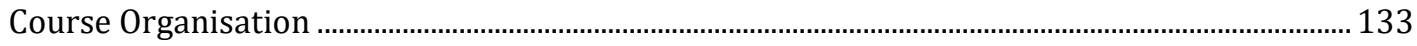

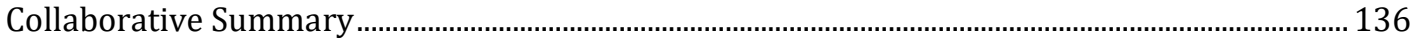

Te Ropu Wahine Maori Toko I Te Ora: Maori Women's Welfare League (MWWL)........................ 138

A Health Research Project And Involvement As Auckland Area Representative....................... 141

Maori Women's Welfare League Golden Jubilee .................................................................................. 143

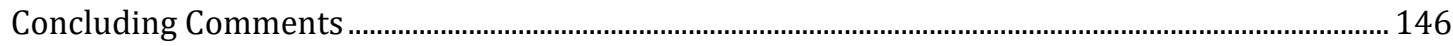

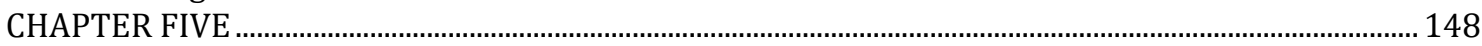

RETIREMENT FROM TEACHING AND ENTERING MY THIRD AGE ..................................................... 148

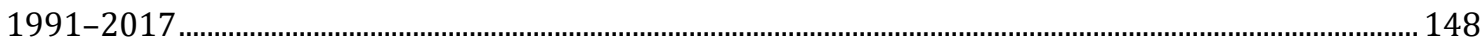

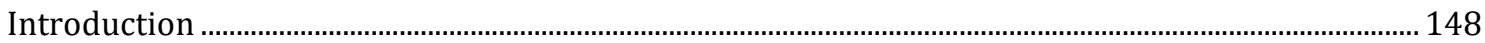

The New Zealand Teacher Registration Board (TRB) .................................................................... 148

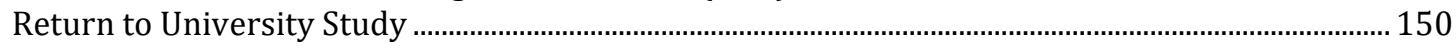

Three Small Research Projects............................................................................................................. 150

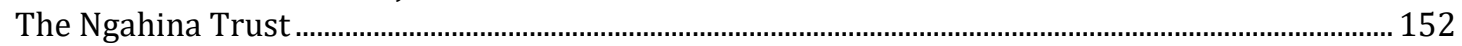

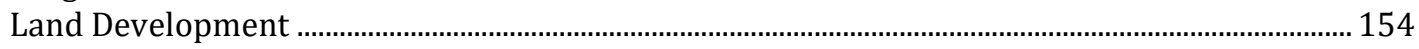

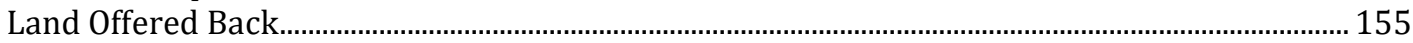

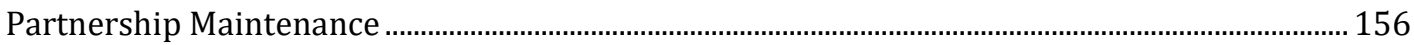

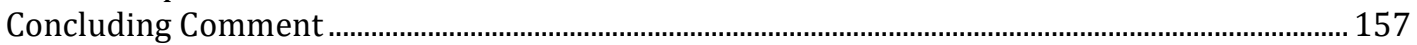

Section Three

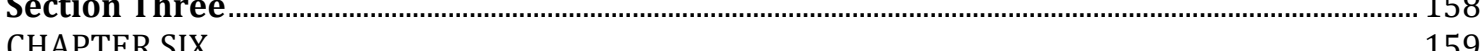

CONCLUSION AND EPILOGUE

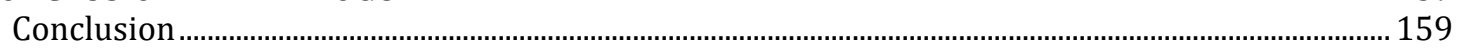

Autobiographical Narrative, A Research Method .......................................................................... 160

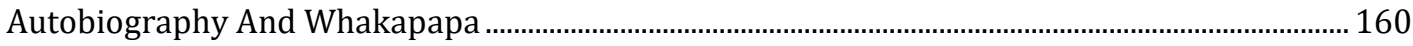

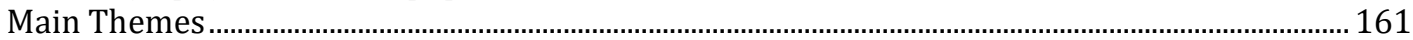

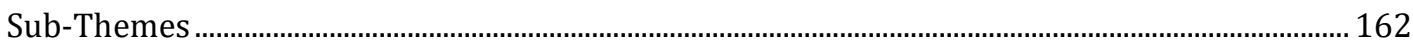

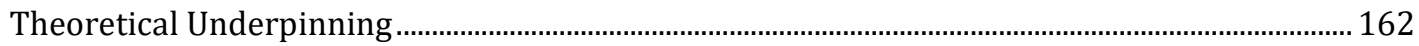

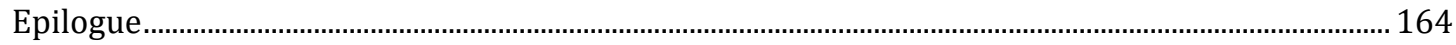

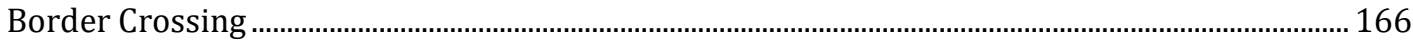

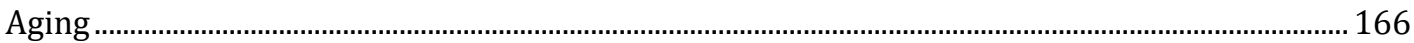

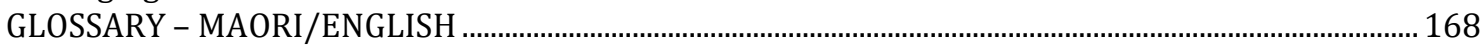

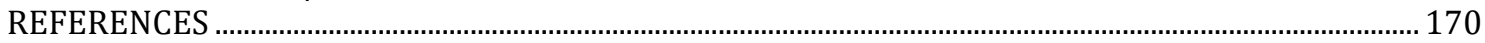

Publications, Reports, Unpublished Work …................................................................................... 170

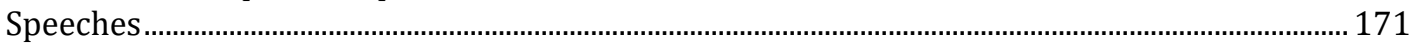

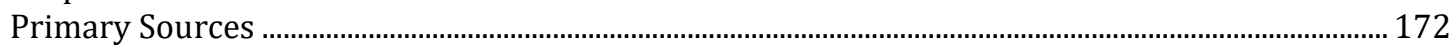

Published Sources and Unpublished Theses and Papers ...................................................................... 175 


\section{CHRONOLOGY OF KURA MARIE TEIRA TAYLOR'S LIFE}

DATE

18 August 1932

$1937-1944$

$1945-1949$

$1950-1951$

1952

$1^{\text {st }}$ February 1953

1954

1955

28 September 1960

1967

$1967-1969$

1969 - June

$1969-1988$

1970

1973 - September

1974

\section{SIGNIFICANT LIFE EVENT}

Kura Marie Taylor is born in Waipapa, Taranaki, to parents, Mouti and Nora Taylor. She was the second child and second daughter of seven children.

Kura attends Waitara District Primary School.

Kura attends New Plymouth Girls' High School.

Kura attends Christchurch Teachers' College and trains as a primary school teacher.

Kura begins her teaching career at Ruatoki Maori District High School as a Probationary Assistant Teacher.

Kura is awarded her Primary Teaching Certificate. At the end of the year, Kura became seriously ill with toxic dermatitis and spent three months at Whakatane Hospital.

After she recovers from her illness, Kura becomes a relieving teacher within the Maori Schools Service.

Kura is appointed Infant Mistress at Ruawai District High School, Northland.

Kura is appointed Infant Mistress at Knighton Road Primary School, Hamilton.

Kura's son, Adrian, is born.

Kura is elected to the Managing Committee, Auckland Branch, New Zealand Educational Institute (NZEI).

Kura is appointed Infant Mistress at Papatoetoe West School.

Kura's Father, Mouti Erueti Mira Teira, dies.

Kura is appointed Infant Mistress at Cornwall Park School. She is the only Maori on staff and there are few Maori pupils. She teaches at the school for nineteen years.

Kura becomes a member of the Arahina Branch of the Maori Women's Welfare League in Central Auckland.

Kura's mother, Gracey Nora Skelton Taylor, dies.

Kura is elected first Maori Woman Teacher President, Auckland Branch, NZEI. 
Kura is elected Maori Women's Welfare League Auckland Area Representative to the Department of Education National Conference, 'Education and the Equality of the Sexes'.

1976-1977

Kura is elected Auckland Area Representative to the Maori Women's Welfare League Dominion Executive.

Kura is elected President, Arahina Branch, Maori Women's Welfare League.

Kura attends the Department of Maori Affairs, Auckland, National Women's Tu Tangata Wananga.

The National President of NZEI invites Kura to accept nomination to UNESCO/WOTCP Peace and Human Rights Consultation in Morges, Switzerland. She is elected Chairperson.

Kura is appointed Advisory Trustee, Ngahina Trust, Kapiti Coast, by the New Zealand Maori Land Court.

Kura is Kaikaranga (first ceremonial caller) announcing the official arrival of Te Tatai Hono, Report on Maori Education, for presentation to the NZEI Annual Meeting in Christchurch.

Kura's article about the Morges Peace and Human Rights Consultation is published in the Department of Maori Affairs magazine, Tu Tangata.

1983 January

Kura is awarded an Advanced Diploma in Teaching by the New Zealand Department of Education.

Kura's son Adrian graduates Bachelor of Commerce from the University of Auckland.

Kura is made a Fellow of the NZEI and invited by the National President to respond on behalf of the Fellows.

Kura is appointed, on the recommendation of the Beneficial Owners, a Responsible Trustee for the Ngahina Trust, Paraparaumu, Kapiti Coast, NZ, by the New Zealand Maori Land Court.

Kura is appointed Director Ngahina Developments Ltd, Paraparaumu, Kapiti Coast, by the Ngahina Trust Beneficial Owners.

Kura is nominated by the NZEI and appointed to the Auckland College of Education Council by the Minister of Education.

Kura graduates Bachelor of Education from Massey University, Palmerston North, NZ.

1987, June

Kura attends the Kawanoa Dawn Ceremony, Blessing of Land, before the beginning of the construction of Ngahina Arcade, Coastlands, Paraparaumu, Kapiti Coast, NZ. 
Kura is appointed to Allendale Girls' Home Visiting Committee by the Minister of Social Welfare.

Kura is appointed Assistant Principal (Junior Classes) at Dawson Primary School in Otara, South Auckland.

Kura is appointed to the National Women's Advisory Committee on Education.

1988, 1 December

1990, 17 November

1991, 1 February

1992, 5 October

1994

2012, 18 August

2013, 17 June

2017, 18 August
Kura's first grandson, Michael Mouti Taylor, is born.

Kura is nominated by the NZEI to the Teacher Registration Board and appointed by the Minister of Education.

Kura and the Auckland Maori Women in Management Group attend a Vice-Regal Reception at Government House, Auckland, to meet with Sir Paul and Lady Reeves.

Kura's second grandson, John Erueti, is born.

Kura retires from teaching.

Kura's third grandson, Anthony Adrian, is born.

Kura is awarded the degree of Master of Philosophy in Education from the University of Auckland. Her thesis, Conversations with Maori Women Educators - Nga Kupu Pāake a Nga Wahine Maori, documents the lives of seven Maori women teachers born $1908-1931$.

Kura celebrates her $80^{\text {th }}$ birthday

Kura's beloved grandson, Michael Mouti Taylor (aged 24), is tragically killed in a car accident.

Kura celebrates her $85^{\text {th }}$ birthday - still swimming in the fast lane. 


\section{SECTION ONE}

Prologue

Chapter One

Chapter Two 


\section{PROLOGUE}

\section{TARANAKI THE MOUNTAIN - THE MOUNTAIN GOD:}

\section{A CHANT OF ADORATION 2}

\author{
Whakawaiwai ai \\ Te tu a Taranaki, \\ o kahu hukarere \\ I huatau ai ko ra. \\ Huhia iho koe \\ O kahu taniko \\ Me tipari koe \\ Ki te rau-kawakawa \\ He tohu aroha \\ Ki te iwi e ngaro nei, \\ Waiho ra e Rangi \\ Kia taria ake \\ Ka tere mai he karere \\ E kore ra e hoki mai!
}

\author{
Enchanting to the eye \\ Art thou, O Taranaki \\ Clothed in thy snowy garment: \\ 0 mountain gloriously arrayed \\ In spotless cloak of glistening white, \\ A robe of radiant beauty! \\ Yon cloud that wreaths thy lofty brow is as a mourning chaplet \\ Soft band of kawakawa leaves, \\ Emblem of sorrow for the dead, \\ Love circlet for the vanished ones forever lost to us. \\ Remain thou there, 0 speak of Rangi! \\ Steadfastly keep thy silent watch \\ For ocean-borne grief messenger \\ For those who'll come no more!'
}

This chant of Mere Ngamai, Te Atiawa poetess, in homage to Taranaki reflects Maori concepts of metaphor in Biblical rhetoric. Te Atiawa Kuia, female elders, say, that in local tradition Taranaki is ascribed the ethos of 'a living entity that no one should think themselves greater than'. ${ }^{3}$ Mauri, the life force of Taranaki enables its people to reach deep inside themselves to draw upon their wairua, personal spiritual power, to maintain the life of their collective for those not yet born, through healthy relationships, reciprocity and reflexivity.

I am tied to this physical landscape of mountain, land and sea. I belong with Taranaki and its spirituality, its symbolism, its multi-layered landscapes and the narratives of my tupuna. This thesis represents my narrative of that belonging as I have navigated and negotiated Maori/Pakeha educational opportunities throughout eighty-five years of my life.

\footnotetext{
2 Cowan, J. (1930). Legends of the Maori. Wellington: Harry H. Tombs Ltd, p. 282.

3 M.T. Tapuke and W.M. TimuTimu, personal communications, Waitara, 2001.
} 


\section{CHAPTER ONE}

\section{NOTION OF 'PLAYGROUNDS', FORMAT, THEMES AND ISSUES}

\section{INTRODUCTION}

Situated within the discipline of New Zealand Studies, this doctoral thesis focuses on my life from birth, as a Maori/Pakeha Woman Teacher in New Zealand primary schools from 1953 until 1991, and then on into my Third Age. The thesis draws on autobiographical narrative to position and locate myself as a Maori/Pakeha woman teacher and to offer some insights into how 'cultural flexibility',4 enabled my navigation of two cultures centralising Maori in relationships and learning encounters with and alongside Pakeha. To address this question the thesis is informed by a number of trans-disciplinary perspectives and draws on the disciplines of Maori Studies; New Zealand Studies; Gender Studies; and History. Implications of identities constructed in power relationships of dialogic encounters at the interfaces of Maori and Pakeha cultures are discussed from the personal perspective of the writer. Challenging aspects of these encounters are evident in attempting to express and interpret nuances of Maori expectations and understanding of events, images and interactions through English language and structures.

\section{Thesis PuRpose}

This thesis is essentially about the construction of an indigenous autobiography. It has a dual purpose: the writing of an autobiography by a Maori/Pakeha woman

\footnotetext{
${ }^{4}$ Carter, P.L. (2010). Race and Cultural Flexibility among Students in Different Multiracial Schools. Teachers' College Record, 112(6), 1529-1574. http://dx.doi.org/
} 
teacher, reflecting on the social and historical construction of her life, together with the issues associated with the actual creation of the autobiographical narrative.

The narrative spans 85 years in the life of a mixed blood Te Atiawa Paake Maori/Pakeha 'cultural navigator'. ${ }^{5}$ Neither bloodline is denied, nor one accorded superiority over the other; but at appropriate times or for functional reasons, 'cultural flexibility' allows one culture to spontaneously occupy more space within an encounter than the other. Story-telling encompasses the voicing and interpreting of many life stories within stories. Many are navigated. Many show a pattern of identity changes for specific purposes. Many are still to be told.

Through reflection and analysis, the project explores the construction of a Maori/Pakeha identity, mechanisms of whakapapa, 'cultural navigation' and 'cultural flexibility'. The personal element of analysing the life, self and the actual construction has been described by British sociologist and historian Peter Willis as:

the importance of the text being located as coming from a particular writer, located... in a social context but also possessing concerns and predispositions which will serve to influence the emerging text in one way or another. ${ }^{6}$

This thesis is intended to add to the social and cultural discourse about Maori/Pakeha women and fill a gap in educational literature.

\section{Explanation OF Format And InTROduction To Notions Of 'Play'}

The life narrative is organised in three sections, under the major overarching theme of 'play in playgrounds'. The format affords space for the discussion of sub-themes and issues arising out of whakapapa: Maori/Pakeha identity, language, resilience and endurance. Dialogic encounters 'played' out through intersecting power relationships between Maori and Pakeha are mechanisms of identity reshaping. I

\footnotetext{
${ }^{5}$ Carter, P.L. (2005). Keepin' It Real: School Success Beyond Black and White. New York: Oxford University Press.

${ }^{6}$ Willis, P. (2002). Inviting Learning. Leicester, UK: NIACE, p.140.
} 
use the concept of 'play' to reconcile the formal and informal material circumstances of my life.

I am the 'player' in the 'playgrounds' of my life. I have enjoyed the process of 'play' as my work. American sociologist Laurel Richardson, in her narrative, Fields of Play: Constructing an Academic Life, describes herself in the fields of sociology, ethnography, theory and gender where she is the 'field' experimenting with textual form. She notes, 'I 'play' as a child plays; 'play' is my work. I enjoy the process.'7 Richardson's writing resonates with my sense of the positive nature of 'play' that permeates my individual, collective, cultural and social learning experiences within three main 'playgrounds', whilst enjoying my work. In this thesis, 'play' epitomises the absorption and reworking of new situational knowledge, the ebb, flow and swirl of constantly moving boundaries to culturally reshape new identities and form new behaviours of practice. Each 'playground' focuses upon my encounters, the strongest influences upon me at that time, and the outcome of my responses.

The Prologue outlines my emotional and spiritual attachment in my belonging to Taranaki. In the human world my Maori/Pakeha identity has been shaped by physical and ancestral landscapes blended with Te Atiawa Iwi and Pakeha social and cultural interests.

Chapter One introduces the thesis, format, concepts of Whakapapa and Maori/Pakeha identity themes and issues located in dialogic encounters, negotiated spaces, language codes, cultural navigation, cultural flexibility, the personal/political nature of encounters and the question of ethics.

Chapter Two canvasses a broad sweep of literature emphasising Maori/Pakeha women and dual identity. Works related to the undergirding theoretical perspectives include: Kaupapa Maori, Maori and Western feminism, Aitanga, autobiography as Maori research methodology, narrative and life stories.

\footnotetext{
${ }^{7}$ Richardson, L. (1997). Fields of Play. New Brunswick, NJ: Rutgers University Press, p. 4.
} 
Section Two, Chapters Three, Four and Five, consists of my life narrative, 19322016, set within the cultural, social and historical backdrop that has contextualized my life. Dialogic encounters were selected and the progressions of my life stages enacted. As English is my first language, the ways in which I have managed issues of those encounters in the dual context of English language and Maori 'body language' are central to each chapter.

Three intertwining strands facilitate the autobiographical approach to explore my navigation of personal and political circumstances and identities. One strand tells a story and describes selected life events. A second strand provides annotated reflections from my present positioning of age and life stage to form linkages between life events, history, culture and the social tapestry of Aotearoa/New Zealand. A third strand briefly analyses selected happenings relevant to each period of time.

Section Three, Chapter Six, indicates Conclusions and focuses on Ngahina Trust as a bridge into the Epilogue.

To reiterate, the notion of 'play' in this thesis emphasises affirmative learning. 'Play' does not trivialise dialogic transactions or the acquisition of knowledge; nor does 'play' marginalise me from conforming to societal conventions. Rather, 'play' frames layers of dialogic meaning and intersections of power relationships whilst retaining the value of positive memorable experiences. I 'play' along with the ideas of others; I 'played' the field as in male and female relationships; and now in the 'playtime' of my third age, I 'play' on. From the time I was born, 'play' and fun have been constant, affirming companions to my personal growth as an individual within a collective, as a group participant and as an individual.

\section{Topic SELECTION}

In 1989 retirement was imminent. I decided to return to university study. Friends and colleagues were suggesting that I write a book about my life. In 1992 I agreed to the request of a close relative to be the subject of a life history research project 
for a Post-graduate Diploma in Women's Studies. ${ }^{8}$ Revisiting that research, and sifting through original tapes and transcripts, triggered memories of my late elder, Mary Turner, articulating her thoughts during interview for my previous oral history study. ${ }^{9}$ Mary spoke about her expectations, and those of her peers, that I write about my own life, declaring, 'If someone else writes about you they will change it all and sell it. You tell it like it is. You do this for us.' ${ }^{10}$ Surrounded by photographs of her Maori and English ancestors, Mary convinced me that our conversation legitimised an autobiographical approach as a method for me, an individual Maori woman teacher, to write about my own experiences. An extension to our linear study really appealed to Mary and her contemporaries. As Linda Smith notes:

Consent is not so much given for a project or specific set of questions, but for a person, for their credibility. Consent indicates trust and the assumption is that the trust will not only be reciprocated but constantly negotiated - a dynamic relationship rather than a static decision. ${ }^{11}$

Implicit in my Elders' gift of knowledge was their approval for me, an independent Maori/Pakeha woman, to write about myself rather than another individual, collective, or Pakeha writing or speaking about me. As for my previous oral histories, reciprocity involved wise use of knowledge. I was caught within the power structure and relationship dynamics of decision-making and approval by my elders to, 'Stand back and be yourself; sometimes you be Maori, sometimes you be Pakeha and sometimes you mix them up'.12 I pondered deeply on their expectations of me, unspoken implications of cultural ethics and obligations, and the issue of public versus private. Linked to my previous oral histories, my narrative would be written mindful of whakapapa, life stories and tribal narratives that delve into events of Maori origins, history and location ${ }^{13}$ relative to my own life. Beginning in the Maori

\footnotetext{
${ }^{8}$ Connor, D.H. (1992). A Life History of Kura Marie Taylor. Unpublished research report, Postgraduate Diploma, Women's Studies, Massey University, Palmerston North, NZ.

9 Taylor, K.M. (1994). Conversations with Maori Women Educators / Nga Kupu Paake a nga Wahine Maori. Unpublished MPhil Thesis, Education, University of Auckland, Auckland, NZ.

${ }^{10}$ Elder Mary Turner, personal communication, Waitara, 1994.

${ }^{11}$ Smith, L. T. (2012). Decolonising Methodologies: Research and Indigenous Peoples (revised edn.). London and New York: Zed Books, p. 136.

12 Elders Mary Turner and Mona Raumati, personal communications, Waitara, 1994.

${ }^{13}$ Riseborough, H. (2002). Days of Darkness (revised edn.). Auckland: Allen and Unwin/Penguin Books NZ, pp. 31, 40, 54-55, 56, 80.
} 
cosmology and travelling through time to the present day, our whakapapa narratives are steeped in a wealth of versions of knowledge that may or may not be accessible for narrative research by individuals. For this thesis, cultural dilemmas of Maori ethics and personal academic research had been clearly resolved in earlier conversations between my elders and me to write about my life.

\section{THESIS TITLE}

The thesis title, Kura Marie Teira Taylor Te Atiawa Paake: Reflections on the Playgrounds of My Life, projects multiple layers of meanings. Taranaki the mountain and the spiritual world of ancestors are, for me, real connections and active relationships lived in the contemporary human world of wide choices. Laurel Richardson has noted that:
Narrative displays the goals and intentions of human actors; it makes individuals, cultures, societies, and historical epochs comprehensible as wholes; it humanises time; and it allows us to contemplate the effects of our actions and to alter the direction of our lives. ${ }^{14}$

Her explanation is a useful complement to the cultural affirmation of my Elders towards my version of my perceptions of my life as a Te Atiawa Iwi Paake in Aotearoa/New Zealand. The important generational connections between my human present and my tupuna lie in my whakapapa stories. Whakapapa 'humanises time,' so that I know with whom I belong, where I belong and how my past is related to my present. The narrative space of 'playgrounds' is where I tell my life story, reflect upon my social and cultural relationships, 'contemplate the effects of [my] actions' and analyse my life experiences, linked to significant social historical events to 'alter the direction of 'my life'. Whakapapa recitation is a male oral ritual. Put simply, when necessary, our family expert publicly presents our whakapapa, while I establish privately with my mokopuna, grandchildren, their linkages to our wider Maori collectives and Pakeha genealogy.

14 Richardson (1997), p. 27. 


\section{Positioning MyselF IN THIS THESIS}

My names, Kura Marie, were bestowed upon me as a legacy of identity through my whakapapa and my Pakeha genealogy. ${ }^{15}$ My patrilineal Teira bloodline descends from the cosmos, to, more recently, Ihakara Te Ngarara, on down through Teira Te Ngarara, Te Newhanga Teira, and my father Mouti Erueti Mira Teira, born 1908. He was from birth to eighteen years the whangai, foster child, of Harimate Epiha, also known as Pirihira Te Ua. My ancestral land ownership through my whakapapa is in the Maori Land Court record.16 Maori to Maori marriages, and whangai by childless, often single women, are characteristic of the Teira line up to the present day. Whakapapa recitation is inclusive of narratives, historical events, relationships, marriage partners, descendants and whangai.

My matrilineal bloodline is a mix of Aotearoa/New Zealand Maori with a Western Pakeha Skelton line from Chelsea, England. That line has been researched by whanaunga, relatives, Lorraine Frost, ${ }^{17}$ Kim Skelton and Helene Connor. ${ }^{18}$ Skelton Maori descend through Te Whiti O Rongomai and his second wife Tarawhakauku; Ngapei Ngatata, married to John George Cooke; Mary Anne Cooke, married to Sergeant George Augustus Skelton of the British Army; George Nepia Skelton, married to my maternal grandmother Mihi Olivia Rahira. My mother, their sixth child, born in 1904, encompassed a bicultural, bilingual synthesis of Maori and English cultural narratives, languages and practices. Mixed Maori/Pakeha marriages characterise the Skelton line. Merging of the Teira and Skelton lineages ensured my Maori/Pakeha life choices, my dual cultural whakapapa being a constant spiritual guiding presence. Kuni Jenkins explains that:

\footnotetext{
15 My Birth Certificate and Maori Land Court succession records show me as Maori, surname 'Teira'. For all school records, New Zealand Drivers' Licence, certificates, awards and for general purposes, I have used my surname 'Taylor'. I assume this began when I was first enrolled at primary school. I chose to use both 'Teira' and 'Taylor', my Maori/Pakeha genealogy, for my Masters Thesis and this project.

${ }^{16}$ Waitangi Tribunal (1996). WAI 143: The Taranaki Report Kaupapa Tuatahi, Wellington: GP Publications. See also Maori Land Court records, Wellington, New Zealand.

${ }^{17}$ Frost, L. (n.d.) Skelton Family History. Unpublished manuscript, in author's possession.

${ }^{18}$ Connor, D. H. (2006). Writing Ourselves 'Home': Biographical Texts, A Method For Contextualising The Lives Of Wahine Maori: Locating The Story Of Betty Wark. Unpublished PhD Thesis, University of Auckland, Auckland, NZ. Available at https://researchspace.auckland.ac.nz/handle/2292/53
} 
Notions of whakapapa are not just about the biological descent lines, but are about the layers of relationships which people engage in through the ages and which people of the same time frame develop between one another in order to create close links through their many and varied events and friendships. ${ }^{19}$

It is the layers of my Maori and Pakeha relationship encounters, navigated flexibly in cultural negotiating spaces, that I, with 'people of the same time frame' explore in this thesis. Similarly, Stanton Wortham notes how 'autobiographical narratives can partly create the narrator's self by interactionally positioning the narrator in salient ways in respect to others' ${ }^{20}$ I am the insider, the outsider; the subjective, the objective; the author; the researcher. I claim at the outset that my reflective autobiographical narrative is influenced by my naming, personal narrative, use of personal pronouns, and spontaneous blending of Maori and Pakeha cultural practices, expectations and obligations.

\section{Voice, LANGUAGE AND AUdience}

The authorial voice is mine, the primary audience is academe. This thesis is a mix of both academic and pragmatic languages. As the writer I speak for myself from within my collective to a diverse audience. Because my bloodlines descend through Maori and Pakeha English cultures, I am comfortable using a mix of Maori and English languages where I feel that form is appropriate. As a Te Atiawa Paake, I speak to Maori and/or Pakeha communities who have been major participants in my journey through life. I am part of their individual and collective perspectives with their culturally bound emphases and languages. It is important to me that those audiences and collectives, are able to access this research in its original form if they so choose. Some readers may recognise similarities or differences to their own lives; some may find aspects to add to the history of their own or collective lives; and some may find a whakapapa link lying dormant, awaiting reconnection.

\footnotetext{
19 Jenkins, K. (2000). Haere Tahi Täua: An Account of Aitanga in Maori Struggle for Schooling. Unpublished PhD Thesis, Education, University of Auckland, p. 45.

20 Wortham, S. (2001). Narratives in Action: A Strategy for Research and Analysis. New York: Teachers College Press, p. 1.
} 
Maori words are now incorporated with English ${ }^{21}$ through legislation, schooling, the media and common usage. The first time a Maori word is used in this thesis, it is followed by the English equivalent, or footnoted. My elders instructed no macrons. Macrons appear as used by authors in cited references only. Some words I use will be recognised by Maori readers as dialectically linking me to my Taranaki, Te Atiawa Iwi home area. If there is any doubt in my mind in respect of blending Maori and English languages, then I resolve that issue with our family whakapapa and te reo adviser or my personal Maori language consultant. A Maori/English glossary is appended for reader clarification.

\section{The Personal is Political}

This research is both a personal and a political statement by and about me, the writer. The thesis explores the events that impacted personally and politically on my life to explain how my identity as Maori/Pakeha was reshaped, but neither culture usurped, in tandem with the practices of Maori and Pakeha socialisation. Social cultural negotiation in paid employment related to professional bodies and community organisation spaces are followed by a discussion of intersecting relationships of my third age and the writing of the thesis.

As Ani Mikaere notes, 'evidence abounds which refutes the notion that traditional Maori society attached greater significance to male roles than to female roles'.22 Western feminist Juliet Williams argues that, "The spirit of "the personal is political" lies in an acknowledgement of power without presuming to settle the question of what role government will play in feminist struggles.' 23 She asserts that the true meaning of the slogan, paramount in Western feminism in the 1970s, is about the

\footnotetext{
${ }^{21}$ Some examples of Maori words in common usage are 'kia ora', for hello or thank you; 'hui', for a meeting; 'mahi', for work; 'mana', for power and authority, 'whanau', for family.

22 Mikaere, A. (1994). Maori Women Caught in the Contradictions of a Colonised Reality. Waikato Law Review, 2: 125-149. http://2.waikatao.ac.nz/law/wlr/1994/article6-mikaere.html

${ }^{23}$ Williams, J.A. (2012). The Personal is Political: Thinking Through the Clinton/Lewinsky/Starr Affair. http://faculty.uml.edu/sgallagher/Williams.htm, 26 March, p. 4.
} 
politicisation of power. Mikaere's comment, on the other hand, indicates that Maori women, many being land owners, already held the kind of political power within Maori social organisations that some Western feminists were seeking in their lives. Much of my public personal political activity began during the 1970s Western feminist movement in Aotearoa/New Zealand aimed to shift the balance of power in the Pakeha workplace to align with general equality of the sexes. In the 1970 s and 1980s as a teacher I was involved in the New Zealand Educational Institute (NZEI), the professional organisation of primary teachers in which I held various offices at local and national levels. I chaired an NZEI National Committee for Equality in Education, and an international consultation in Morges, Switzerland, on Peace and Human Rights. I also held offices at local, regional and national levels in Te Ropu Wahine Maori Toko i te Ora, the Maori Women's Welfare League. From 1990 to 1996 I was a full member of the New Zealand Teacher Registration Board. From 1994 I have been politically active as the Ngahina Trust Chairperson in matters of family Maori land for commercial development and leasing.

\section{A Question OF ETHICS}

I reiterate, as with my previous oral history project the practice by older Maori women of oral consent or oral verification placed upon me, the writer, specific obligations and responsibilities about wise and ethical use of information I received during my life time. Because I reflected on myself and my life, using a variety of memory triggers, no interviews were conducted and no written consent forms were required. When any of my family, peers or friends asked about my project, I welcomed their comment, confirmation and oral permission of verification, recorded as personal communication throughout the text. I have used names sparingly after obtaining oral approval, or in cases of demise, only if their names already appear in publications or research. Pat Sikes notes that, 'writing is never neutral or innocent because it is a social and political activity with consequences ... [and] carries a heavy ethical burden'. ${ }^{24}$ This thesis is an honest endeavour to share 
85 years of my life as I perceive it. It is not a confessional. Inevitably my perceptions of the consequences and ethical practices framed by my interpretation of my reality will differ from how others have perceived me from their realities.

The nature of much of my adult life involvement with, for example, the New Zealand Educational Institute (NZEI), the Auckland College of Education Council (ACEC), the New Zealand Teacher Registration Board (NZTRB), and at present with Ngahina Trust and Ngahina Developments Limited, has required compliance to legislation, codes of conduct related to ethical standards, confidentiality and public versus private domains.

Any doubt in presentation has been resolved by my unequivocal decision to write around, withhold, or substitute another event. This has respected anonymity for those participants in narrated dialogic transactions. There are many of whom I have been privy to personal information in carrying out my responsibilities. I have continued to respect that confidentiality. Others, I believe, own the telling of their participant experiences in which we engaged, so for them, anonymity has been preserved by omission. As a personal political autobiographical narrative, it is possible that some readers may recognise themselves as participants because of the nature or time of an event. Any breach of commission or omission is mine.

Discretion about the use of personal correspondence, personal journals and electronic mail addressed to me has been exercised. Material labelled, embargoed, confidential, and not in the public domain has been respected, regardless of time. Material directly referenced to this thesis will be held for a limited time by me in secure storage.

\footnotetext{
${ }^{24}$ Sikes, P. (2010). The Ethics of Writing Life Histories and Narratives in Educational Research. In Bathmaker, A. and Harnett, P. (Eds), Exploring Learning, Identity and Power Through Life History and Narrative Research. London: Routledge/Falmer, pp. 11 -24.
} 


\section{CHAPTER TWO}

\section{NARRATING MY 'SELF'}

\section{INTRODUCTION}

Chapter Two locates my research project with relevance to Maori and indigenous peoples within the literary genre of autobiography and autobiography as research methodology. The methodology takes into account the merging of the requirements of academe, the personal and the community. Autobiography is time and culture specific. Its cultural specificity may be interpreted as both culturally reproduced and culture productive as it not only portrays but also creates social reality.

This chapter offers an explanation into how the autobiographical methodology is compatible with Matauranga Maori, Maori knowledge, Kaupapa Maori theories, Aitanga and Mana Wahine Maori Feminism. I explore the shaping of my 'Self', my identities and the constraints of autobiographical narration from my present stance as a Te Atiawa Iwi Maori Paake woman teacher.

\section{GroWth OF Western, MaORI AND Indigenous Autobiography}

Historically Western autobiography has evolved to become a site of female specificity and subjectivity, reflecting the autobiographical 'Self' and identity. Liz Stanley notes that the dominant autobiographical classical archetype inscribes what a life looks like, the form in which (written or spoken) tales of lives should be told and actual lives should be lived. Lives are linear, chronological, progressive, cumulative and individualistic, and follow highly particular narrative conventions. ${ }^{25}$

\footnotetext{
25 Stanley, L. (1992). The Autobiographical I: The Theory and Practice of Feminist Auto/biography.
} Manchester and New York: Manchester University Press, p. 12. 
Australian Jill Ker Conway ${ }^{26}$ is one of many auto/biographers who trace Western autobiography along an historical continuum from epic poems and religious confessions to the contemporary political power arenas of gender, ethnicity, class, theory and critique. She notes the discursive commentary of the increasingly powerful women's voices that burgeoned from the mid-nineteenth into the twentieth and twenty-first centuries. These took the form of privileged women's narratives. ${ }^{27}$

\section{MAORI AND INDIGENOUS AUTOBIOGRAPHY}

While once Maori may have hesitated to write or speak about themselves, present day Maori autobiographical writers claim Maori identity indigenous to Aotearoa/New Zealand. There may be a declared link to Maori history, whakapapa, genealogy, tikanga, Maori cultural practices, connections to ancestral land, and use of or some familiarity with Te Reo Maori, Maori language. Some show colonised disruption to Maori identity. In all cases, Maori autobiography centralises Maori and focuses on making a difference for Maori, whether authored by Maori, Maori/Pakeha or empathetic non-Maori. One area where there is a paucity of critical texts in the field of autobiographical narrative research is in the lives of Maori/Pakeha women teachers. This thesis is intended to begin to address that gap.

\section{AUTOBIOGRAPHY AND TEACHERS}

Charmaine Pountney's autobiography is one of the very few life histories about the life of a teacher in Aotearoa/New Zealand. She wrote of her own growing up, schooling and employment years, encapsulating years of experience with a wide range of multi-cultural learners from pre-school to tertiary, and Kura Kaupapa, Maori language immersion learning:

I've spent nearly 60 years in and out of our education system as a learner, a teacher, a principal, a dean, a community educator, a

\footnotetext{
26 Conway, J. K. (1998). When Memory Speaks: Reflections on Autobiography. New York: Alfred A. Knopf, pp. 3-18.

${ }^{27}$ Conway, J. K. (Ed.) (1994). Written By Herself: Autobiographies of American Women. New York and London: Vintage Books, pp. viii-ix.
} 
counsellor and advocate for rejected students and parents. I've taught people as young as one year, as old as 90 , on outside decks and verandahs, in living rooms, offices, kitchens, classrooms, orchards, computer rooms and huge auditoriums.

I've also observed education around the world, read voraciously everything to do with teaching, learning and schools, and been even more a learner than a teacher all my life. ${ }^{28}$

An oral example comes from Miraka Petrecevitch Szaszy, 'the seventh of eight children to a Maori mother and a Yugoslav father'. ${ }^{29}$ A trained teacher and university graduate, Miraka spoke about her experiences at a time when few women held positions of power. Miraka was born into Te Aupouri and Rarawa tribes in a materially poor far North Aotearoa/New Zealand Maori settlement during the Great Depression. Following the death of her mother, she was cared for by her father, siblings and others. She was labelled Tararara and teased because of her mixed Maori and Yugoslav blood. Her Maori heritage sustained her. In 1936 she was sent to Queen Victoria Boarding School for Girls in Auckland, and fostered by a caring Auckland family through painful, humiliating schooling experiences. She went to Auckland Teachers' Training College and, with a University study scholarship, graduated in 1945 and then went on to Postgraduate study at the University of Hawaii. Despite assimilation schooling policies at that time, Miraka retained her Maori language, and her ways of being Maori, and was academically successful. As a young Maori Welfare Officer, her fight for Maori social justice was an outcome of her schooling and life experiences of racism, sexism and unjust practices in housing, employment and education. Miraka became President of the Maori Women's Welfare League and confronted the invisibility of Maori women on the Marae. She was a key speaker at the 1973 Auckland United Women's Convention, ${ }^{30}$ later working with young Maori women in the setting up of the Ministry of Women's Affairs. Miraka's driving force was channelled towards effecting change to inequalities and social positioning of Maori women in the home, the workplace and on the marae. 31

\footnotetext{
28 Pountney, C. (2000). Learning Our Living: A Teaching Autobiography. Auckland: Cape Catley, p. IX. 29 Mira Szaszy (1986). In Myers, V., Head and Shoulders: Successful New Zealand Women talk to Virginia Myers. Auckland: Penguin Books NZ, pp. pp. 232-249.

${ }^{30}$ Coney, S. (Ed.) (1973). United Women's Convention 1973 Report, Auckland: UWC, pp. 21-24.

31 Taylor (1994).
} 
A different example of a whole life autobiography is Sonja Davies' account, in two volumes, of what became her high-profile Aotearoa/New Zealand life from 1923 to 1997. Whakapapa, genealogy, links Sonja to Ngaitahu Iwi. ${ }^{32}$ She records insights into her political activism and the dynamics of socio-political power relationships. Her autobiography details her achievements, her determination for peace, and her championing of the rights of women, despite deeply traumatic personal circumstances. Sonja's writing is 'an amalgam of all that has happened'. ${ }^{33}$ Her autobiography is a highly relevant feminist reference for underpinning similarities to political issues, power relationships, and women's rights, similar to some of those that I have experienced as a Maori woman teacher.

In Reweti T. Kohere's autobiography of his whole life from 1871,34 traditional Maori growing up, schooling, theological training and attitudes feature strongly. He describes a social/cultural/political view of rural Maori life, family and community involvement on the east coast of the North Island of Aotearoa/New Zealand during the late nineteenth and early twentieth century. I recall my mother's memories of similar aspects of her growing up, family and community involvement, which persisted in some form during my own growing up years.

The wider sphere of indigenous autobiographical narrative posits similar indicators of cultural markers to those of Maori such as, attachment to land, culture, history, social organisation, specific tribal dialectic language, and relationships. ${ }^{35}$ Autobiographies from the American South, for example, as James H. Watkins points out, depict a deep-rooted attachment to place, where, 'a sense of personal identity is intimately intertwined with both the physical and cultural landscape... with its

\footnotetext{
${ }^{32}$ Ngaitahu Iwi is a large Maori tribal organisation located across the South Island of New Zealand. ${ }^{33}$ Davies, S. (1997). Bread and Roses (originally published 1984). Auckland: Random House NZ, p. viii; Davies, S. (1997). Marching On. Auckland: Random House NZ.

${ }^{34}$ Kohere, R. T. (1951). The Autobiography of a Maori. Wellington, NZ: A. H. \& A. W. Reed.

35 The reference list has many examples of auto/biographical accounts of Maori women's' lives, including those in collections and collaborative works, for example Kay Douglas (2001); Witi Ihimaera $(1993,1998)$; and Kathie Irwin and Irihapeti Ramsden (1995). Maori women's photographic images and autobiographical statements can be found in Michelle Moir (1994). There are profiles of Maori women achievers in Amy Brown (Ed.) (1994). For interviews with Maori Women's Welfare League founding members, as told to Dame Mira Szaszy, see Szaszy, Rogers, and Simpson (Eds) (1993); for Whina Cooper, see Michael King (1983); and for Amiria Stirling, see Anne Salmond (1976).
} 
rhythms of speech, its patterns of social interactions, its history - even its cuisine'. ${ }^{36}$ Maori lives display some similarities with slave narrative content and concepts of place, multi-layered linkages between land, people, and historical events.

Hertha Dawn Wong, writing about Native American autobiography, asserts that before European arrival, 'indigenous people had numerous oral and pictographic forms in which to share their personal narratives ... in different forms, with different emphases, for different audiences and purposes' ${ }^{37}$ She suggests that for many indigenous peoples, their identity not only locates them with family, clan and tribe but also in 'a spiritual context to place one's self in relation to the cosmos'. ${ }^{38}$ This communal interdependent approach resonates with Maori spirituality and tribal social organisation in Aotearoa/New Zealand, showing a difference between indigenous and Western views of narrated identity and self.

\section{Autobiography AND MAORI ORAl Literature}

Maori philosophy presents the view that knowledge originates with the Gods. Maori oral literature centres on intermediary demi-gods whose relationships bridge the world of the Gods with the world of the living. Linda Tuhiwai Smith reminds us that Tane-nui-a-Rangi was one such demi-god, who struggled through to the twelfth heaven to bring back to earth three separate baskets of highly specialised knowledge, each part of which 'was essential to collective well-being'. 39 Ranginui Walker cites this same demi-god whose adventures resulted in setting many precedents for Maori social behaviour. 40 The importance of the status of women was acknowledged in the role of Goddess. ${ }^{41}$ Two examples are Hinetitama, the Dawn Maid, and Hinenuitepo, Goddess of the Underworld. ${ }^{42}$ Annie Mikaere

\footnotetext{
36 Watkins, J.H. (Ed.) (1998). Southern Selves: From Mark Twain and Eudora Welty to Maya Angelou and Kaye Gibbons, A Collection of Autobiographical Writing. New York: Vintage Books, p. xiv.

37 Wong, H.D. (1992). Sending My Heart Back Across The Years. Oxford: Oxford University Press, p. 12.

38 Wong (1992), p. 14.

${ }^{39}$ Smith (2012), p. 175.

40 Walker, R. (1996). Nga Pepa a Ranginui. Auckland: Penguin Books NZ, p. 2.

41 Walker (1996), pp. 18-20.

42 Te Rangihiroa/Buck, P. (1940). The Coming of the Maori. Christchurch: Whitcombe and Tombs for The Maori Purposes Fund Board, pp. 452-453.
} 
suggests, 'that Maori women occupied very important positions in traditional society, positions of military, spiritual and political significance'. ${ }^{43}$ As such, Maori women lived in vastly different autobiographical spaces to those of Western women.

Further, Ranginui Walker asserts that traditionally Kuia, usually women elders:

are the keepers of knowledge, which the young need to succeed in the world. Kuia do not surrender their knowledge lightly, because its possession is central to their own status and mana. For this reason the Kuia transmitted their knowledge to a carefully selected descendant. ${ }^{44}$

James Belich states that Maori, 'were very interested in their past and preserved it carefully in oral tradition'. ${ }^{45}$ Processes of remembering were assisted by integration of many types of knowledge strands. A. T. Ngata and P. Te Hurinui record significant examples of oral literature strands linking Maori to historical events. ${ }^{46}$ Ritual recitation and testimony to deeds of generations of tribal heroes and heroines and in laments composed following battle embody elements of tribal auto/biography. Similarly, James Cowan notes that Maori oral literature records epic feats of conflict and male warrior prowess equal to any of the classical Greek and Scandinavian heroes. ${ }^{47}$ Stories told through whakapapa, genealogical relationships, visual arts of cave drawings, paintings, carving and kowhaiwhai; music of women's sung chants, and oriori, lullabies, are further examples of oral and visual literature.

\section{Te Reo MaOri, MaOri Language}

Of the three baskets of knowledge carried from the heavens by Tane-nui-a-Rangi one contained a precious taonga, a gift from the Gods of Te Reo Maori, language of traditions, history, rituals, and the manner of expressing nuances of being Maori. According to Maori academic Te Kapenga Dewes, 'Maori literature rests on the

\footnotetext{
43 Mikaere (1994), p. 3.

44 Walker (1996), p. 20.

45 Belich, J. (1996). Making Peoples: A History of the New Zealanders. Auckland: Penguin Books NZ, p. 22.

46 Ngata, A. and Jones, P. Te Hurunui (1972). Nga Moteatea. Wellington: A. H. \& A. W. Reed for the Polynesian Society.

${ }^{47}$ Cowan, J. (1930). Legends of the Maori. Wellington: Harry H. Tombs Ltd.
} 
foundation of Maori language. This language is still the most essential feature of Maori culture, which as a way of life continues to be dynamic.' 48 He goes on to state:

Our literary tradition is a creative one because it draws on the indigenous past, and borrows, changes and continues to comment on and adapt to contemporary situations. It is a living tradition extending continuously from the past to the present. From our oral heritage. 49

Mihipeka Edwards, in her three-volume whole life autobiography, ${ }^{50}$ has a particular focus upon loss of Te Reo Maori and her dedicated plea for retention, because for her, loss of the Maori language meant loss of identity. Her extended family organisation, marked by collective survival strategies in a rural setting, was later compromised in a hostile urban social environment discouraging Te Reo Maori usage.

\section{AUTOBIOGRAPHY AND THEORETICAL UNDERPINNINGS}

Kaupapa Maori theory, as argued by Graham Smith,,51 has empathy with Maori, is about Maori, defined by Maori, for Maori and is explicably implicated within my autobiographical narrative. In the words of Linda Tuhiwai Smith, theory is important for indigenous peoples':

At the very least it helps make sense of reality. It enables us to make sense of the world in which we live. It contains within it a method or methods for selecting and arranging, for prioritising and legitimating what we see and do. Theory enables us to deal with contradictions and uncertainties. Perhaps more significantly, it gives us space to plan, to strategise, to take greater control over our resistances. The language of a theory can also be used as a way of organising and determining action. It helps us to interpret what is being told to us, and to predict the consequences of what is being promised. Theory can also protect us because it contains within it a way of putting reality into perspective. If it is a good theory it also

\footnotetext{
48 Dewes, Te K. (1977). The Case For Oral Arts. In King, M. (Ed.), Te Ao Hurihuri, revised edn. Wellington: Hicks Smith, p. 47.

49 Dewes (1977), p. 53.

${ }^{50}$ Edwards, M. (1990). Mihipeka: Early Years. Auckland: Pengun Books NZ; Edwards, M. (1992). Mihipeka: Time of Turmoil Nga Wa Raruraru. Auckland: Penguin Books NZ; Edwards, M. (2002). Mihipeka: Call of An Elder, Karanga A Te Kuia. Auckland: Steele Roberts.

51 Smith, G. H. (1997). The Development Of Kaupapa Maori:Theory And Praxis. Unpublished PhD Thesis, University of Auckland, Auckland, New Zealand. Cited also by Leonie Pihama, 2001, 84.
} 
allows for new ideas and ways of looking at things to be incorporated constantly without the need to search constantly for new theories. 52

Kaupapa Maori provides the platform for two key theories, Aitanga and Mana Wahine Maori Feminism. It also provides a framework for critical examination of the relationship of Maori and Pakeha knowledge with my Maori/Pakeha woman teacher/learner identities throughout my growing up, schooling, paid employment years, and third age activities. Their articulation is significant to the theoretical culturally legitimate underpinning of this thesis on the one hand as inclusive and expressive of commonalities across iwi, hapu and whanau activity, and on the other as adaptation and absorption of Pakeha differences. Kaupapa Maori theory is being increasingly used by Maori researchers and writers to question Western ideology and Otherness. Kaupapa Maori theory engages complex multi-layered meanings of language, te reo Maori, in the context of Maori knowledge, Maori time, space and Maori women. Kaupapa Maori theory, Aitanga and Mana Wahine Maori Feminism spontaneously blend with Pakeha practices to provide a reservoir of knowledge upon which to draw to hone supportive strategies.

\section{AITANGA}

Kuni Jenkins notes that Maori cultural and relationship practices have evolved from traditional ideas through borrowing and adaptation, in similar ways to colonising cultures. She discusses the practice of Kaupapa Maori and the concept of Aitanga as the mechanisms through which Maori rational thought operates. She notes that Aitanga is 'a framework or set of principles with which to discuss the Maori experience and the relationships which have developed over time between Maori and Pakeha'. ${ }^{53}$ Her principles embody highly complex broad concepts of pluralism, multi-layered meanings and linking threads to explain four essential features of Aitanga, and how Maori formed relationships.

\footnotetext{
52 Smith (2012), p. 40.

53 Jenkins (2000), p. 15.
} 
- The first concept of mana, power, explains Maori belief in personal power when actively engaged in social encounters. ${ }^{54}$

- The second concept of wehi, fear, has both negative and positive aspects. As a cultural mechanism wehi is used either as an element of social control and the cementing of peaceful relationships, or as a vehicle for learning and teaching. 55

- The third concept of aroha, a spiritual emotion, relates to bonding relationships between individuals and groups characterised by diversity in age and life stage development. ${ }^{56}$

- The fourth concept, manaakitanga, caring, links to aroha as generosity of hospitality, nurturance and protection within a family, towards relatives, visitors and wider groups of people. Relationships are a key factor in manaakitanga. ${ }^{57}$

She asserts that:

Maori thought and action are tied within the elements of Kaupapa Maori. The elements shape the way Maori are able to conduct and weave the fabric of their society. Their traditional social organisation aligned with their practice requires a highly disciplined and ordered set of customs. From the mechanisms/elements of Kaupapa Maori have evolved the distinct and recognisable patterns of behaviour - tikanga - which show how Maori have socialised themselves in particular ways in order to relate with others. ${ }^{58}$

She argues the value of Aitanga as a theoretical framework to redescribe the social world in Maori terms, and 'ensure the visibility of active Maori participation in past and future social change'. ${ }^{59}$ How I developed relationships during my life reflects aspects of the concepts of mana, wehi, aroha and manaakitanga espoused by Kuni Jenkins, as well as Pakeha behaviours and conventions. Aitanga has particular relevance in this thesis, where power relationships are perceived subjectively through my Maori/Pakeha woman teacher lenses. Aitanga underpins my Self, the

\footnotetext{
54 Jenkins (2000), p. 50.

55 Jenkins (2000), pp. 51, 54.

56 Jenkins (2000), p. 55.

57 Jenkins (2000), pp. 56, 58.

58 Jenkins (2000), pp. 43-44.

59 Jenkins (2000), p. 26.
} 
interactive communication languages of cultural navigation, negotiation of relationships within a third space, and boundary crossing to reshape my identities and form lasting relationships that I have established during my life.

\section{MANA WAHINE MAORI FEMINISM}

Mana Wahine Maori Feminism theory and discourse is about Maori women, relationships, status, mana, intrinsic personal and psychic power. Within the boundaries of Kaupapa Maori theory, Leonie Pihama notes, 'The theoretical frameworks of Mana Wahine have emerged as a means... to describe Mäori women's analyses. They are Mäori women's views of the world, which are located in Mäori women's experiences and understandings of the world'. 60 Denise Henare comments that Maori women had rangatiratanga, chieftainship power, 'in the sense that the exercise of rangatiratanga was integral to the way in which Maori society operated. At times it was superior to the authority of men. It provided a cohesiveness to decision making, values and the development of Maori society'. ${ }^{61}$ According to Annie Mikaere, there are numerous examples of mana held by powerful Maori women before, and resulting from colonisation. ${ }^{62}$

Helene Connor offers ten principles for Maori Feminism, using Maori sources of data to:

- maintain collective vision and self-determination rights for Maori women;

- acknowledge balance between individual and whanau;

- acknowledge whakapapa, secular and spiritual connections;

- incorporate Kaupapa Maori theoretical principles, Maori language, and tikanga Maori;

- recognise physical, spiritual and psychological dimensions;

- recognise subordination of Maori women through inequalities of gender, race and class;

\footnotetext{
60 Pihama, L. (2003). Interview in Smith, H. (Ed.), Taiawhio: Conversations With Contemporary Maori Artists, Wellington, NZ: Te Papa Press, p. 106.

${ }^{61}$ Henare, D. (1994). Interview in Brown, A. (Ed.), Mana Wahine: Women Who Show the Way.

Auckland: Reed Publishing, p. 21.

62 Mikaere (1994).
} 
- recognise colonised erosion of Maori identity and promote active support for the resurgence of Maori women;

- create their own theories and discourse;

- incorporate both male, mana tane and female, mana wahine discourses alongside each other;

- actively promote Maori feminism research method. ${ }^{63}$

Kathie Irwin affirms that Maori Feminism:

... is clearly pro-Maori. Maori Feminism is an integral part of Maori development. It seeks to re-establish the mana wahine of our women, to allow us to stand tall beside the men in our whanau again. Not in front of them, the movement is not anti-men, nor behind them, we are not apologetic about our strength or our visions, but beside them where our culture tells us we should be. We need to create relationships, roles and understandings of the status of Maori women that are relevant to our culture today. ${ }^{64}$

A prime example of Maori Feminist principles in action within a pro-Maori organisation is the very successful Ngahina Trust, referred to earlier and in detail in Chapter Five, in which I have a leadership role and where women are the majority landowners.

Navigation of my way through my Kaupapa Maori/Pakeha world reflects the sociological imagination that Peter Willis brings to the identity debate, arguing that:

Autobiography also engages the imagination. It does not show individuals necessarily as they were or even as they are. Rather, it expresses what they believe themselves to have been and to be. Thus the self is not something to be discovered through autobiography. It is in fact something to be imagined and constructed. 65

Laurel Richardson uses sociological imagination in her 'fields of play' approach, described earlier, to examine 'how context affects our writing and how our writing affects ourselves',66 to transform us to become what we are. During a major

${ }^{63}$ Connor (2006), pp. 45-60.

64 Irwin, K. (1993). Maori Feminism. In Ihimaera, W. (Ed.), Te Ao Marama 2, Regaining Aotearoa: Maori Writers Speak Out. Auckland: Reed Publishing, p. 299.

65 Willis (2002), p. 146.

66 Richardson (1997), p. 5. 
intellectual crisis in her working life, she questioned the entire sociological enterprise and sociology's claim to authority. As the 'field' in 'fields of playing, she contextualises the construction of her academic life in pleated text and an interplay of essays and papers spanning ten years. She argues that narrative provides access to unique human experiences of time, and that actors carry out their everyday lives in specific time frames where biographical, cultural, and collective stories overlap and intersect. The autobiographical process separates the uniqueness of one individual's existence from others contributing to understanding leading to social and generational cohesion and change.67 In articulating her own dilemma in narrative form and interaction with like-minded colleagues, her own stance was resolved.

The importance of articulation and verbal practice in interactional positioning is highlighted by Stanton Wortham. He describes the function of narrative discourse in the construction of Self and the transformative power of autobiographical narrative as a scene where characters and events are represented and relationships established. He notes that, 'narratives can partly create the narrator's self by interactionally positioning the narrator in salient ways with respect to others' ${ }^{68}$ Maori scholars reclaim similar spaces of interactional positioning where differences become visible and centralised. In Aotearoa/New Zealand, anthropologist Joan Metge argues for similarities and differences between Maori and Pakeha use of English in social transactions. ${ }^{69}$ I reiterate, as my narrative unfolds, the transformation of my Maori/Pakeha identities are expressed within Laurel Richardson's sociological imagination of 'play' and the relationships I have established in interactional positioning with Maori, Pakeha and others from my infancy through my third age.

Peter Willis ${ }^{70}$ argues for storytelling, through exhibited Australian indigenous paintings, as an expressive, qualitative research method for autobiographical

\footnotetext{
${ }^{67}$ Richardson (1997), pp. 12-31.

68 Wortham (2001), p. 1.

${ }^{69}$ Metge, J. (2010). Tuamaka: The Challenge of Difference in Aotearoa New Zealand. Auckland: Auckland University Press.

70 Willis, P. (2002).
} 
narrative. Storytelling encompasses personal roles that show what writers believe they were, and when they were writing. His re-collection role is about how a person sees the world and their place in it. His performance role is in the act of sharing experiences, presenting self with a focus on its character as something designed to have a particular impact on those reading it. His reflective role expands on Morwenna Griffith's first personal narrative stage, what 'occurs when people turn their minds to themselves to their activities, feelings thoughts and judgements and become attentive to them and the influences which shape them'. ${ }^{71}$ People, each as knowledgeable insider and objective authorial outsider, are centralised.

As Morwenna Griffiths notes, standard autobiography 'as simple, individual, personal narrative, is just a first stage, and of only limited use for the purposes of gaining knowledge'. ${ }^{72}$ It needs to be reflected upon. It needs to be analysed. In Chapter Six I combine elements of being Maori/Pakeha, Peter Willis's roles, and Robert Bullough and Stefanie Pinnegar's guidelines, with aspects from the Self and Culture studies of Jens Brockmeier and Donal Carbaugh. ${ }^{73}$ Recollection conveys my cultural world view. Performance narrates my selected past and present events located in time and space. Reflective mode links my life narrative, my Maori/Pakeha woman teacher identities, research methodology, literature, theory, analysis and the transformation of my Maori/Pakeha 'Self' throughout my life stages.

\section{Autobiography, My ‘Self’ and My Maori/Pakeha Identity}

My autobiographical narrative contained within this thesis is critical autobiography about a working class Te Atiawa Iwi Maori/Pakeha Paake. I reiterate, it is both personal and political. This self-study project crosses disciplinary boundaries, is inclusive, and takes cognisance of Maori and Pakeha differences and similarities in the collection and use of historical data, analysis and the telling of my story, as my

\footnotetext{
71 Willis (2002), pp. 139-145.

72 Griffiths, M. (1995). Feminisms And The Self: The Web of Identity. London and New York: Routledge, p. 70.

73 Bullough Jr, R. V. and Pinnegar, S. (2001). Guidelines For Quality In Autobiographical Forms Of Self-study Research. Educational Researcher 30(3), 13-21; Brockmeier, J. and Carbaugh, D. (Eds), (2001). Narrative and Identity Studies in Autobiography, Self and Culture, Vol. 1. Amsterdam, PHL: John Benjamin.
} 
'Self' and my identities reshape over time. As Morwenna Griffiths notes, 'Critical autobiography ... makes use of individual experience, theory, and a process of reflection and re-thinking, which includes attention to politically situated perspectives. ${ }^{74}$

Autobiographical narrative engages my experiences in reflection, re-thinking, theory, and my Maori/Pakeha identity construction. It interrogates my life data, memorabilia, book stacks and seeks out supplementary literature to expand concepts of the three main thesis themes. Firstly, Maori/Pakeha Identity acknowledging my naming and my mixed blood heritage. Secondly, negotiation spaces of social interaction where I am a cultural navigator in power relationships, politics and theory, exemplified in Homi Bhabha's 'hybridity and a third space of in betweenness', 75 noted by Paul Meredith as 'blurring the limitations of boundaries and calling into question established categorisations of culture and identity;; 76 or Richard White's 'middle ground', where American Europeans and Algonquin Indians 'came together to find ways of co-existing'. ${ }^{77}$ Thirdly, Mason Durie describes his concepts of time, resilience and endurance in the wider political forum and context of Maori indigeneity. He notes that, 'time can be used as a coordinate to give meaning to events, people and places',78 and that 'resilience recognises adversity and triumph, and celebrates strength of purpose and a capacity to survive ... Maori endurance is about time and resilience'. ${ }^{79}$ Like Sidonie Smith's concept of identity as a physical body, ${ }^{80}$ my identities constantly interact with my external environment, crossing and recrossing boundaries whilst spontaneously reshaping my identities and long term practices.

\footnotetext{
${ }^{74}$ Griffiths (1995), p.70.

75 Bhabha, H. (1998). The Third Space: Interview with Homi Bhabha. In Rutherford, J. (Ed.), Identity: Community, Culture, Difference. London: Lawrence and Wishart, 207-221, p. 207.

${ }^{76}$ Meredith, P. (1998). Hybridity in the Third Space: Rethinking Bi-cultural Politics in Aotearoa/New Zealand. Paper presented to Te Oru Rangahau Maori Research and Development Conference, 7-9 July, Massey University, Palmerston North, New Zealand, p. 3.

77 White, R. (1991). The Middle Ground: Indians, Empires, and Republics in the Great Lakes Region, 1650-1815. Cambridge, UK: Cambridge University Press.

78 Durie, M. (2005). Ngā Tai Matatū: Tides of Māori Endurance. Melbourne: Oxford University Press, p. 1.

${ }^{79}$ Ibid.

80 Smith, S. (1994). Identity's Body. In Ashley, K., Gilmore, L., and Peters, G. (Eds)., Autobiography and Postmodernism. Boston: University of Massachusetts Press, pp. 266-267.
} 
Mason Durie also notes:

Essentially 'research at the interface' aims to utilise the energy from two systems of understanding in order to create new knowledge that can then be used to further development. Development involves harnessing the new knowledge, and might require different ways of conceptualising situations or even novel technologies that can transform research findings into practical applications. $^{81}$

His explanation offers an insight into my third age involvement with the Ngahina Trust. In a commercial development arena I am a Maori/Pakeha cultural navigator, spontaneously blending two cultures integral to relationships. New knowledge is harnessed in practical profitable application for the expansion and growth of Ngahina Trust and Ngahina Developments Limited.

According to Irihapeti Ramsden:

Life for all those who come from minority or different cultures is often spent on an emotional and spiritual frontier. The distances, the no-ones lands, the number of borders which one is able to negotiate dictate the way we cope with our frontier life......For some people the border crossings are few. One world or the other may provide a safe and comfortable refuge. For others there are reluctant and unhappy crossings, often without their consent. Yet others in this colonised land find themselves dwelling in the worlds of neither one nor the other. Neither fully comfortable in the tight world of the Pakeha nor in te ao Maori. ${ }^{82}$

My readings led me to ponder upon my Maori/Pakeha 'Self', my world and my place in it; who I see my 'Self' to be; what knowledge I store for spontaneous filtered retrieval to enable my 'Self' to move forwards; adaptation by my 'Self' to forge a way through two cultures whilst retaining my Maori identity; powerful influences that impacted upon my 'Self'; survival strategies and processes honed by my 'Self'; why my 'Self' was drawn to teaching; how my 'Self' fits my roles as Trustee/Chairperson of a highly successful Maori Land Trust; and what continues to drive my 'Self' in my comfortable cultural space as Maori/Pakeha.

\footnotetext{
81 Durie (2005), p. 141.

82 Ramsden, I. (1993). Borders and Frontiers. In Ihimaera, W. (Ed.)..), Te Ao Marama 2, Regaining Aotearoa: Maori Writers Speak Out. Auckland: Reed Publishing, p. 345.
} 
As I perused my personal memorabilia, life documents and book stacks, positive and negative life experiences with people were revealed. In Nod Miller's linking of theory with her learning and life experiences, she commented on an indigenous friend's bookshelves that a 'number of the authors were members of an invisible college which constituted a version of an extended family in my consciousness' ${ }^{83}$ She adapted her understanding of indigenous blood ties and obligations to her own symbolic extended family comprised of authors, colleagues and acquaintances gathered on her own bookshelves, influencing her learning and the way she thought about herself. I similarly value my memorabilia and book stacks, as I value the people who have touched my mind and my life. I often loiter there to appreciate the fine, critical, analytical minds and the relationships it continues to be my privilege to re-visit mostly now, through printed memory. These are my 'members of an invisible college' in academic learning and research, my past, present and future, whose printed signposts along my pathways of social relationships reflect many lasting friendships and experiences. Mason Durie notes, 'Identity is not primarily an inner experience or personal conviction, rather it is a construct derived from the nature of relationships with the external world' ${ }^{84}$ The three main themes Maori/Pakeha identity, negotiation spaces described by Homi Bhabha; and Mason Durie's time, resilience and endurance emerged out of my meandering reminiscences. Jeffrey Weeks asserts that:

Identity is about belonging, about what you have in common with some people and what differentiates you from others. At its most basic it gives you a sense of personal location, a stable core to personality, and the complex social relationships with others. ${ }^{85}$

Hana O'Regan explains identity similarly to describe personal identity as being about knowing the individual Self, and collective identity as being about knowing the linkages connecting the Self to knowing and understanding Self's individuality, Self's relationships and Self's place in the world. ${ }^{86}$ She notes that 'identity refers to

\footnotetext{
83 Miller, N. (1993). Personal Experience, Adult Learning and Social Research. Publications Thesis Series, Centre for Research in Adult Education for Human Development, University of South Australia, p. 36.

84 Durie, M. (2001). Launching Maori Futures. Wellington: Huia Publications, p. 50.

85 Weeks, J. (1990). The Value of Difference. In Rutherford, J. (Ed.), Identity, Community, Culture, Difference. London: Lawrence and Wishart, pp. 88-100, p. 88.

86 O’Regan, H. Ko Tahu, Ko Au: Kai Tahu Tribal Identity. Christchurch: Horomaka Publishing, p.32.
} 
the feelings and beliefs shared by members of a group regarding their relationships to each other and the world around them'.87 I reiterate, my identity lies in my belonging to Taranaki te Maunga Tapu, the lands of my Tupuna, ancestors, the threads of their Kaupapa Maori and Pakeha ways of being, culture, knowledge, beliefs, values, relationship linkages and life practices evolving from them in their time to me in my time. Sidonie Smith's description of identity as a physical body captures these concepts in constant internal ebbing and flowing through capillaries and veins ligatured to origins and genealogy to circulate the blood of discourse through the flesh of textual self-writing covered in autobiographical skins. Skin is the boundary, the interface between my identities body and the material circumstances of my social, political and power environments. Here, interaction generates relationships and language as identities shape, reshape, connect, disconnect, pause, merge or overlap. ${ }^{88}$

Indigenous Australian John Moriarty also particularises his skin of identity:

In this system your parent's skin group automatically determines what your skin group is ... It's a very structured classificatory system that determines your relationship with others, and who you should and should not marry ... Through the skin group system I am automatically related to others within the traditional Aboriginal system. Your skin group gives you authority in certain things, but at the same time you have certain obligations ... It can mean having responsibilities to certain land ... This responsibility makes you feel secure in many ways, but it also enables you to contribute back to your people and uphold the tribal system. Everyone is part of the mosaic that makes up the cultural landscape, which in turn spreads over the country. ${ }^{89}$

Both Sidonie Smith's and John Moriarty's strong articulations of skin's relationship to identity resonate significantly with the multi-layering of meaning interpreted in my being Maori/Pakeha. Inside the boundary of my Maori/Pakeha skin, the bloods from my forebears ebb and flow, constantly reshaping identities across the landscapes of my life.

87 O’Regan (2001), p. 33.

${ }^{88}$ Smith, S. (1994).

${ }^{89}$ Moriarty, J. with McHugh, E. (2000). Saltwater Fella. Melbourne: Viking Penguin Books, pp. 3-4. 


\section{CONSTRAINTS OF AUTOBIOGRAPHICAL RESEARCH}

As already noted, the paucity of literature in the field of Maori/Pakeha woman teachers has been a theoretical and methodological constraint. Using my own experiences has also been constrained by the nuances of language necessary to reach my Maori/Pakeha, academe, research and personal audiences. Being in close proximity to the topic as the subjective/objective insider/outsider has posed difficulties in relation to my experiences, related to how and what is to be written in, and what is to be left out. In attempting a balance I have used a story form of narrative focussed on memory. However, my memories are constrained by the changing language forms of memory's time to the telling at this particular time. To trigger my memories and validate my remembered experiences I have turned to my living family, extended family, friends and colleagues who have participated in my various social interactions; my memorabilia of presentation gifts, silver trays, pottery, books, international and miscellaneous objects gathered during my travels; my life documents of personal files, certificates, awards, speeches, diaries, cards, letters, photographs, emails, various conference papers, travel diaries, travel information and my personal book stacks.

My claim to being Maori/Pakeha woman teacher brings into focus the constraints of colliding world views arising out of two distinctly different cultures, languages, dual cultural identities and status that spontaneously generate my Maori/Pakeha culture. My narrative will show that I have long been a comfortable social and cultural border crosser. Traditionally Maori female and male roles, obligations and responsibilities were clearly delineated. Even though time may have blurred those differences, certain forms remain. For example, in knitting together my whakapapa lines I can welcome guests with the first call to, or from, the marae, but cannot have a speaking role in the ritual of greetings. Nor may I project myself as better than others simply by accidents of history, culture and ethnicity. For Maori, subtle meanings of respect, value and status are carried in unique whakapapa connections. Respect rather than disrespect also demands that I use few personal names in my narrative text, because naming would make some visibly important and others unfairly invisible. Authors whose work is referenced throughout my thesis are 
respectfully attributed full name status in the text itself, to avoid confusion between writers, ensure accurate scholastic acknowledgement of all cited authors and texts, and avoid the use of surnames only.

In attempting to complete this project, I have also been physically constrained since 2007 with left and right full hip replacements; release of right carpal tunnel; removal of cataracts for left and right eye lens implants; acquisition of hearing aids; and Type 2 diet-controlled diabetes diagnosis. But, as a survivor, I persist in 'playing' on. 
SECTIONTWO

Chapter Three

Chapter Four

Chapter Five

Life Narrative 1932-2016 


\section{CHAPTER THREE}

\section{AUTOBIOGRAPHICAL NARRATIVE AND REFLECTIONS}

$$
\text { 1932-1949 }
$$

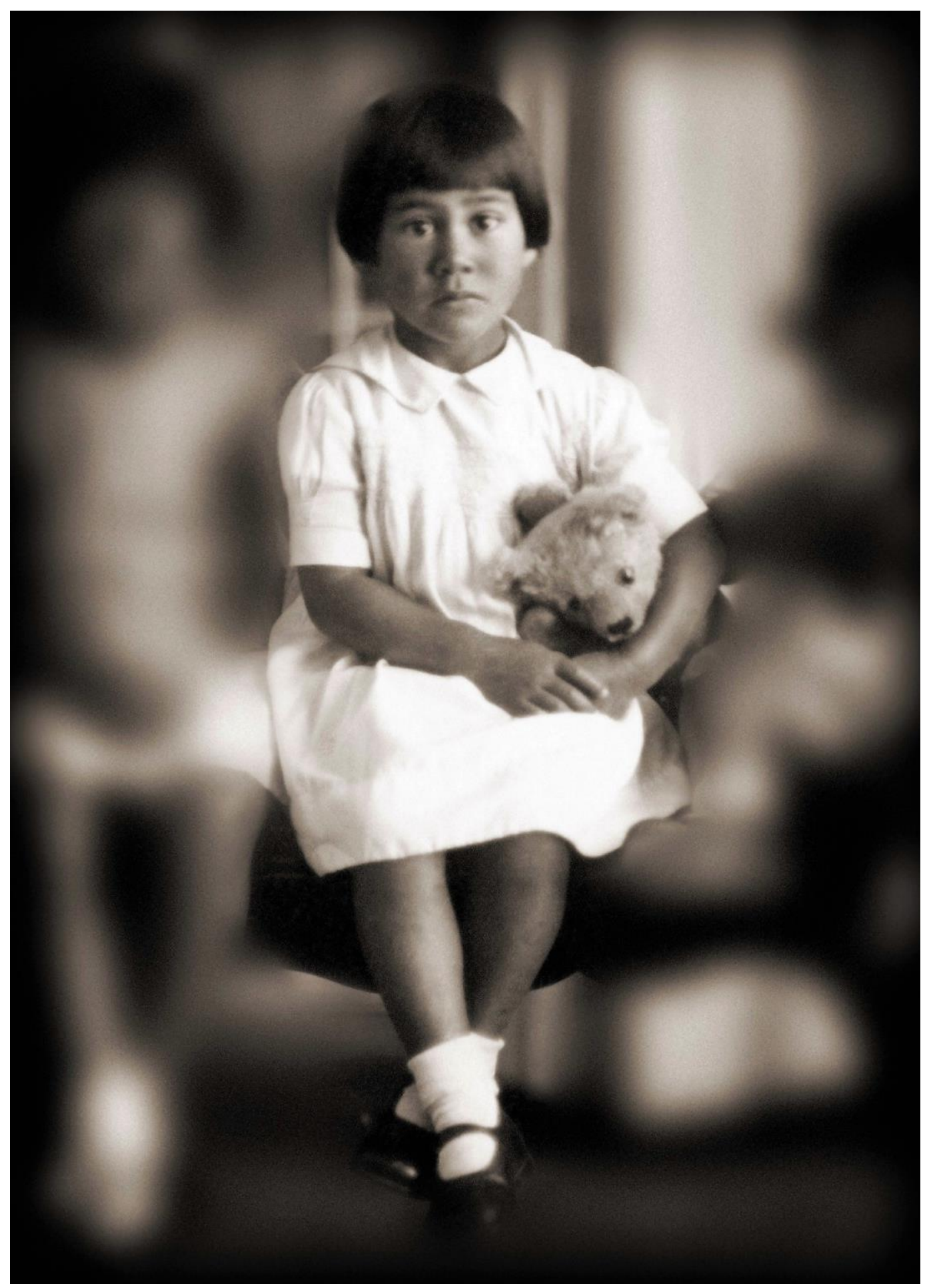

Figure 1. Kura Marie Teira Taylor, aged four, 1936. 
INTRODUCTION

Chapter Three, Section One, locates me through whakapapa from birth at Waipapa on 18 August 1932, during the stringent economy of the Great World Depression. Our material circumstances were impacted upon, as were the ways we created our own fun and early 'play'. The Depression and World War II also affected our schooling and social conventions for the post-war life my working class Maori/Pakeha parents determined for me.

Waitara - Town OF the Mountain River

Waitara has a history of turmoil steeped in the sorrow of land and culture invasion with unjust colonial confiscation of the PekaPeka block for the 'Waitara Township'..$^{90}$ Waitara is the small town I was familiar with as a child dominated by the original Owaea Maori Village site from a high bluff on the eastern river bank overlooking the old Maori war canoe anchorage and the west bank township.

WAITARA - A FREEZING WORKS TOWN

Waitara grew to be a freezing works town, employing generations of Maori and Pakeha families serving the farming hinterland. In 1894 the New Zealand Frozen Meat Company built their slaughter house and chilling works on the west bank of the Waitara River. In 1903 the Works was sold for $£ 20,000$ to Thomas Borthwick of London, to whom is attributed the prosperity that year from frozen meat exports. In 1904 fire destroyed the Works, and by 1905 the new building was completed. A slump in 1908 caused a temporary closure of the Works. A wharf was built, and for the next fifteen years frozen meat was carried by lighter down the river and across

90 Waitangi Tribunal (1996), pp. 67-82. 
the sand bar for loading overseas on ships anchored off-shore. ${ }^{91}$ By 1920 the river had silted up and the river mouth had become more hazardous, so frozen meat was transported by railway to the port of New Plymouth. In a massive 1937 rebuild, the Works became the most spectacular in the Southern Hemisphere. ${ }^{92}$ During its operational period, Maori laboured and Pakeha office executives managed the racist, classist Works. Maraea Tippins states: 'The Maori families who didn't still live on the farms were working here at Waitara at Thomas Borthwicks freezing works ... it was the main industry here at Waitara'. ${ }^{93}$

Our father laboured in the freezing chambers and was often called on a Sunday evening to load frozen carcasses into the refrigerated train trucks for transport to the port of New Plymouth. Our uncle, Roy Pennington, with other stock drovers and dogs moved cattle and sheep over long distances to the Waitara Works for slaughter and freezing. The Works employed permanent workers. Large numbers of seasonal and university student itinerants were also accommodated in on-site single men's huts during spring and summer.

The significance of Waitara in this thesis is as the important descriptive backdrop to my early formative years when, in the words of Paul Reeves, our 'mother fashioned me'. ${ }^{94}$ Surrounded by my extended family and community, my multiple selves emerged in their first construction to reshape and mature over my life stages from female infant, to girl, to woman, to Elder.

\section{Central Themes}

\footnotetext{
91 Alexander, A. C. (1979). Waitara: A Record Past and Present. New Plymouth, NZ: Taranaki Newspapers for New Plymouth Borough Council, p. 72. A Norwegian Sea Captain, Olé Anton Bernsten, had seen barges working on rivers and canals in Europe. He conceived the idea of using barges to take the frozen meat from Borthwicks Freezing Works down the river to be loaded at sea. Captain Bernsten was also awarded the George Medal for Bravery at sea. B. and P. Darney, personal communication, 2014.

92 Alexander (1979), p. 63.

93 Tippins, M. (1993). Maraea Tippins. In Szaszy, M., Rogers, A., and Simpson, M., Early stories from founding members of the Maori Women's Welfare League, Te timatanga tatau tatau, Te Ropu Wahine Maori Toko i te Ora. Wellington: Maori Women's Welfare League and Bridget Williams Books, p. 281.

94 Ihimaera, W. (Ed). (1998). Growing Up Maori. Auckland: Tandem Press, p.153.
} 
Three main themes interwoven with reflections contextualise the narrative. Firstly, Whakapapa, Family, Identity establishes the 'players' and their linkages. ${ }^{95}$ Secondly, Cultural Flexibility and Dialogic Encounters position 'players' in 'ongoing dialogue with other speakers', ${ }^{96}$ progressing knowledge, growth, and spontaneous cultural 'border crossing'97 of interacting Maori/Pakeha with other 'players'. Thirdly, Resilience and Endurance, framed by Mason Durie as an inner force and an indefatigability' for honing survival strategies embedded in dual Maori/Pakeha cultural practices and social relationships. ${ }^{98}$

The empirical evidence in this section will show our mother's powerful influence during my early years in cementing the solid foundation of my Maori/Pakeha family whakapapa, genealogical connections and identity. The consistency and freedom of dialogic encounters and social relationships in my early 'play' and schooling environments that mark my developing cultural flexibility will become more apparent. These components, together with the safety and vibrant community influences of Maori/Pakeha lifestyles, cultural frontiers, border crossing and an ability 'for turning adversity into accomplishment', ${ }^{99}$ are integral to the continuing growth of resilience and endurance basic to my survival as a Maori/Pakeha female.

\section{WHAKAPAPA, FAMILY, IDENTITY}

My Maori/Pakeha cultural self identity was rooted in generations of Te Ao Maori, the Maori World View, ${ }^{100}$ through linkages in my Te Atiawa Iwi whakapapa well before I was born until more recent cultural flexibility with the Pakeha World. My English great grandfather, Sergeant George Augustus Skelton, fought with the British troops against Maori in the 1860 land wars. He and Te Piki Ngatata, also known as Mere Kuku or Mary Anne Cooke, married in the late 1860s. ${ }^{101}$ In both racial and cultural terms, the identity strands of Pakeha whiteness and Te Atiawa

\footnotetext{
95 Walker (1996).

96 Wortham (2000), p.1.

97 Ramsden (1994), p. 345.

98 Durie (2005), p.1.

${ }^{99}$ Ibid.

100 Walker (1996), pp. 13-31.

101 Connor (1992), p.4.
} 
Iwi Maori brownness were merged into my maternal Skelton line. As children of our parents, we became the third Maori/Pakeha generation. I have no doubt our parents knew stories about the effects of the land wars on their families but they chose not to pass them on to us.

My Te Atiawa Iwi Maori Teira paternal whakapapa linked our Father's land inheritance within the surveyed boundaries of Waitara township to three acres, then in a nineteen acre block of Maori freehold land held in multiple ownership with his cousins. Originally the land was the site of Teira's village. ${ }^{102}$ A family urupa, Maori cemetery, the house that became our home, and a safe extensive 'playground' for us were all part of the block. Unlike those who were brought up Maori 'driven by te reo and tikanga, which create a distinctive identity',103 we used English as our everyday language even though our Mother was a fluent speaker of both languages. I never ever heard our father speak in Te Reo Maori. Our Maori speaking grandparents did not live with us, so we had no consistent Te Reo Maori language model.

I can only speculate that perhaps because our parents were rural, rather than urban dwellers, they had developed the resilience to survive the 1918 Spanish Influenza epidemic better than some. I also assume that during the Depression of the 1930s when I was born, their subsistence lifestyle continued until we moved to Waitara, away from daily access to our Maori family speakers, and our father started work in the freezing works. It was inevitable that our parents' decisions for us were a composite of survival experiences they had endured during tumultuous world events that impacted upon their local circumstances. As MereMere said in an interview, 'a Marae to me is the University of Maoridom when it comes to culture and Te Reo'. ${ }^{104}$ We were not taken to the Marae, tangi, Maori bereavements, or any Maori gatherings because of likely exposure to respiratory infections, sickness, tuberculosis, measles and sexually transmitted diseases that were rife at that time.

102 N.T. Teira, personal communication, 2000.

103 Ihimaera (1998), p.112.

104 Taylor, K. M. and Matthews, K. M. (2016). Korerotia Mo Nga Paake: Maori Women Educators Speak. In Panayotidis, E. L. and Stortz, P. (Eds), Women in Higher Education, 1850-1970:

International Perspectives. New York and London: Routledge Taylor \& Francis Group, 228-250, p. 238. 
Very occasionally our mother took us to the Manukorihi Pa when she played tennis there as a member of the Raukura Tennis Club, or walked us to the Maori Mission Chapel. I recall her singing Te Reo Maori hymns and songs, and home visits by the Maori Minister and the Maori Missioner.

Through reflection, I am certain that our parents believed that we would, over time, come to understand our Te Atiawa Iwi Maori links. Meantime our mother ensured we had the social tools to keep ourselves safe. We learned to make informed future choices about our Te Atiawa Iwi Maori cultural space, and to interact confidently with either Maori or Pakeha. In the long term we were to be independent selfsufficient Maori/Pakeha.

\section{SEVEn TAYLOR CHILDREN}

My older sister Neta was born in 1930. I arrived next in 1932. Then my three brothers were born, Dennis in 1935, Maurice in 1937, and Leo in 1939. We were home birthed and breast fed. I remember babies in the close comfort of being carried in a blanket on [her] back'.105 Our placentas and umbilical cords were traditionally buried and returned to the spiritual embrace of Papatuanuku, our Earth Mother, anchoring us to our ancestral lands, and to the deeds, dreams and consequences of our forebears. My aunt, Heeni Te Wharemaru, describes being brought into the world by her father in a mud-floor ponga house, and how 'the umbilical cord would be wrapped in several layers of material and immediately taken away and buried. It was given back to the earth and its burial place was considered very special'.106 Aunty Heeni was 'given away as a young woman to serve the Church and her people for most of her life'.107 I recall the preparations for my youngest brother's home birth, and being sent to the neighbour's house. Sister Anderson, the Pakeha midwife, came in the afternoon and Dr Barclay arrived later.

\footnotetext{
105 Ritchie, J. (1970). The Maori Background. In Ewing, J. and Shallcrass, J. (Eds), Introduction to Maori Education: Selected Readings, Wellington: New Zealand University Press, Price Milburn and Co., p. 51.

106 Te Wharemaru, H. with Duffie, K. M. (1997). Heeni: A Tainui Elder Remembers. Auckland: Harper Collins, p. 31.

107 Weiler, K. and Middleton, S. (Eds) (1999). Telling Women's Lives, Narrative Inquiries In The History Of Women's Education. Buckingham, PHIL.: Open University Press, p. 64.
} 
The 1938 Social Security Act introduced the Maternity Benefit, which provided for hospital care. For the benefit to be claimed, a doctor had to provide antenatal 'supervision'.108 In 1944 my identical twin sisters Dawn and Diane were born in the Waitara Maternity Annexe, where their placenta and umbilical cords were disposed of. The District Health Nurse made home visits to monitor the progress of mothers and Maori babies. They were breast fed and bottle fed too. (Lloyd Chapman notes that 'Maori were never represented in the Plunket movement',109 which provided the majority of home visits.) I remember there was great excitement in the community when the twins were born. We were all baptised into the Anglican Church.

In reflecting upon our home birthing, only the twins' placenta was not treated in the traditional Maori way, because of their Maternity Annexe birth and our mother's Pakeha lineage. The placentas of our Pennington and Skelton cousins, born in the Maternity Annexe, were also treated in the Pakeha way. Mihipeka Edwards, however, writes that her 'father was very, very good at helping with the births. He had to be because there was no money for doctors, and doctors weren't going to come miles and miles through the bush to come to a Maori woman'. ${ }^{110}$ Kura Te Waru Rewiri states, 'After my birth my placenta was buried in a place set aside for the placenta of newly born babies, which was not far from our family urupa. The placenta is buried to connect you to the land and has given me a strong spiritual journey through life.'111 Merimeri Penfold spoke of her mother's stillborn babies, 'and others she lost in the early stages of pregnancy. These babies and their placentas were taken, by my father, to the local cemetery, the urupa, and buried there'. 112

I also reflected upon my collective and cultural selves thriving in the inclusion of our Maori/Pakeha extended family with whom we were in regular contact. We were

108 http://canterburyhomebirth.org.nz/history-of-birth-in-nz/. Retrieved 29 November 2017. 109 Chapman, L. (2003). In a Strange Garden: The Life and Times of Truby King. Auckland: Penguin Books NZ, p. 169.

110 Edwards (1990), p. 17.

${ }^{111}$ Highfield, C. (1999). Kura Te Waru Rewiri: A Maori Woman Artist. Wellington: Gilt Edge Publishing, p. 1.

112 Shepard, D. (2009). Her Life's Work: Conversations with Five New Zealand Women. Auckland: Auckland University Press, p. 79. 
embraced in whanaungatanga, caring kinship, friendship and control. Cultural flexibility between Maori and English cultures was a spontaneous transfer process embedded in daily dialogical encounters of engagement. Eventually our Waitara extended family claimed 32 child cousins; seven Penningtons, eleven Skeltons, seven Taylors, and seven Taiakis. They were born to local uncles and aunts, older mostly Maori women, in Waitara working and Motunui farming families known by, or related to, our parents. My memories of our grandmothers and grandfathers are vague because we seldom met. They died when we were quite young. I remember an old voice calling, "E Kura-a-a-a'! and I assume it was my grandmother. I also recall camping at the Karaka Flat by the Waitara River during the whitebait season with Kui, Grandmother Ngakuru, Aunty Lulu Skelton's mother. I recollect a time when Kui Ngakuru slow-cooked, for three days, karaka berries or what she called koldoldols, kotoretore, 'sea anemonies'.113 I remember one visit of Grandfather Tim Skelton to see us in Waitara. He became sick and was taken in a taxi to New Plymouth hospital. I recall Koro, Grandfather Mira Teira, waving to us from a jigger $^{114}$ on the railway lines as he passed by.

\section{OUR PARENTS}

Our outgoing confident mother was born in 1904 into a horse-and-cart rural farming family at Motunui. Her biological mother, Mihi Olivia Rahira, died giving birth to her youngest son. Our mother was brought up by her stepmother Tangiora in a Te Reo Maori/English bilingual household. Our uncles, Mother's brothers, Harold George Nepia Skelton and George Daniel Skelton, are listed in the World War 1 Nominal Roll of the Second Maori Contingent, and sailed on the SS Waitemata on 19 September 1915.115 Harold died of wounds in France on 8 August 1917, aged 23. His younger brother, also wounded there, was repatriated home.

113 See Burton, D. (1982). Two Hundred Years of New Zealand Food and Cookery. Auckland: Bateman, p. 12.

114 'Jigger' was the term we used to describe a heavy platform with wheels that fitted the railway tracks. One or two men sat on the platform and moved the contraption along by pushing a central lever with handles backwards and forwards, as a form of transport to places where the railway needed maintenance.

115 Pugsley, C. (2006). Te Hokowhitu A Tu. The Maori Pioneer Battalion in the First World War.

Auckland: Reed Publishing, p. 96. 
Our mother's life was devoted to our nurturance and English language socialisation in what was considered 'women's work'. As was usual then, she 'undertook primary responsibility for cooking, cleaning, child-raising and daily household management'. 116 Specific social divisions delineated women's and men's work, but like many farming women of her time she crossed male/female role boundaries, chopped wood, carried water, dug the garden and cleaned out water tanks. She went to school until Standard Two. After an altercation with the Headmaster's son, she refused to return, but stayed at home mothering the family while her stepmother regularly visited Manukorihi Pa in Waitara for long periods of time.

Our quiet taciturn father, born in 1908, experienced urban lifestyles at Petone and Waitara. After work he usually enjoyed the Pakeha 'pub culture' with his Maori and Pakeha workmates in one of the three local pubs. Jock Phillips has written about the colonial Pakeha male stereotype:

Drinking in the pub became a central test of male identity for many New Zealand men ...The male exclusiveness of the pub also produced a peculiar atmosphere of male camaraderie. The six o'clock swill was always crowded ... The exclusion of women from the pub affected men's attitudes towards women. ${ }^{117}$

As I reflect upon my Maori/Pakeha whakapapa and family, I do not recall our father being violent towards us because of the pub culture he chose; rather he was a sleepy toper. I often speculate that perhaps the school event in our mother's early life helped define her expectations and determined drive about our education. This was exemplified in her adamant repetition of the current view at that time: 'You will go to school and you will have a good education and you will get a good job. Maori won't get you a decent job.' I reiterate that I believe she was orientated to preparing us for lives of informed choices and independence, different from the subsistence living, minimal schooling and second class citizenship of her early years. In her physically labour intensive domestic life, our Mother exerted a powerful, loving, sensible influence over us based on her known family skills. Our father's natural

116 Montgomerie, D. (2001). The Women's War: New Zealand Women 1939-45. Auckland: Auckland University Press, p. 23.

117 Phillips, J. (1996). A Man's Country? The Image of the Pakeha Male. Auckland: Penguin Books NZ, p. 78. 
reticence did not appear to contradict this view, but provided additional opportunities for our reading and responding to body language encounters. Again, I am sure that our parents, like all parents, wanted us to be able to enjoy a life better than theirs had been.

\section{PARENTING}

Traditional Maori myth and legend place children as precious gifts descending from their primal parents, Ranginui the Sky Father and Papatuanuku the Earth Mother. 'Maori place a high value on having children, which they consider one of the main purposes of life and marriage.'118 In comparison with Pakeha, large Maori families were common. All children, regardless of birth circumstances, were recognised and included in their bloodline families. In Maori biological and extended family communities, siblings, aunts, uncles, grandparents and others participated in the parenting process, and children 'had to learn the dynamics of group living'. ${ }^{119}$ James Ritchie notes:

The difference between Maori childhood and Pakeha childhood is a difference of people, of attitudes, of places, and of culture.....their lack of self-consciousness in their relationship with their children and their frank enjoyment of them. Children are to cuddle and to carry, to play with and to spend one's time with. And this attitude is shared by other people with the Mother. ${ }^{120}$

\section{WhANGAi PARENTING}

Up to the present day some Maori children are still parented, usually with a relative, in a whangai relationship, a form of Maori adoption, fed 'not only with food but with affection and instruction, to nurture in the full sense of the word'.121 Whangai children know who they are, their bloodlines, where they belong and their roles in life. They have multiple relatives, may visit their other family regularly and may

\footnotetext{
118 Metge, J. (1976). The Maoris of New Zealand: Rautahi. London: Routledge and Kegan Paul, p.143. 119 Rangihau, J. (1981). Being Maori. In King, M. (Ed), Te Ao Hurihuri: The World Moves On. Auckland: Longman Paul, p. 165.

${ }^{120}$ Ritchie (1970), p. 49.

121 Metge (1976), p.144.
} 
inherit from both whakapapa lines. The position of whangai and inherited tribal rights can become a sensitive issue if they are outside tribal whakapapa bloodlines. ${ }^{122}$

Our father and a female cousin were whangai children from birth until completion of schooling, with Harimate Epiha, also known as Pirihira te Uru, a childless woman relative who lived at Paraparaumu and Petone near Wellington. When he was eighteen and ready for employment, our father was sent back to Waitara. As an adult he went regularly to visit Pirihira, his whangai mother. My aunt explained their dialogic encounter: 'One day there was a knock at the door. I opened the door. I called, Mum! There's a man at the door! He said he's my brother!'123 My father had returned to his biological family. I have cousins who were also whangai with two of my aunts. Other cousins, each from a very young age, over many years, experienced similar shared whangai nurturance during regular extended visits, or long holidays, to the same specific friends or relatives of their parents. Childless women were often given a child relative to foster, particularly when families were large.

In large families where older siblings were responsible for younger siblings, parenting was also practised in tuakana/teina relationships. Learning was a twoway process, by the younger from the older or by the older from the younger. Donna Awatere Huata writes, 'When I was born my eldest sister was twenty-one so she took me. She brought me up.'124 Helene Connor discusses tuakana/teina mothering roles and responsibilities in her mother's family, our Motunui cousins. ${ }^{125}$ Sometimes, as in the case of the death of a mother, children were parented by their fathers within their collectives. After the death of Mira Szazy's mother, 'The older children looked after my brother and me, and other people around kept an eye on us. ${ }^{126}$ After the death of her mother, MereMere was parented by her grandmother until the grandmother passed on, and she was then parented by her father. ${ }^{127}$

\footnotetext{
122 O’Regan (2001), p.55.

${ }^{123}$ N. T. Teira, personal communication, 2014.

${ }^{124}$ Awatere Huata, D. (1996). My Journey. Auckland: Seaview Press, p. 8.

125 Connor (2014), p. 233.

126 Myers (1986), p. 255.

127 Taylor and Morris Matthews (2016), p. 238.
} 
My reflections of our parenting are of a two-parent family home, with a cultural mix of Pakeha semi-urban and Maori tuakana/teina interactions.

\section{LANGUAGE}

My siblings and I heard a mix of Te Atiawa Iwi Te Reo Maori dialect, and English language. We imitated behaviours and absorbed lifestyle practices. From their reality, our parents chose English and Pakeha interactive conventions for us. Language was important and we grew very quickly into everyday usage of English, matching various 'speaks' in situational dialogic encounters. While verbalising enjoyment, pleasure, frustration or achievement, we knew where the lines were drawn between 'adult speak' and 'child speak' and we respected those limitations. 'Home speak' was within our immediate and extended families; 'school speak' for classrooms and playgrounds. 'Play speak' applied to 'playing' games and moving power as we took turns, organised, or simply participated, won or lost games. 'Shopping speak' bought goods and services. 'Church speak' framed Sunday School, Church, prayers, choir and religious rituals. 'Baby speak' was definitely not allowed, nor was speaking during meals. I recall also the 'play' of song and conversation during, for example, preparations to bath, powder and dry a wriggling baby. Afterwards, walking the kitchen floor singing to the baby while our mother tidied up; rocking the baby in the pram; mashing prunes and vegetables to feed the toddlers; dragging my youngest brother to picnics in the paddock; and general learning 'play' about looking after babies and younger siblings while being brainwashed in domestication encounters. In the course of these dialogues, I also heard about 'dirty Maoris' who lived in 'Maori houses', and didn't look after their 'kids' or their 'Maori dogs.' I knew we were different from them. Our mother also often recited English aphorisms of the Victorian period, such as: A stitch in time saves nine. Too many cooks spoil the broth, A bird in the hand is worth two in the bush. Procrastination is the thief of time. As English speakers we were seen to follow our Pakeha Skelton linkages. We were often labelled as 'too Pakehafied' and therefore not 'real Maori'. ${ }^{128}$

128 O'Regan (2001), p. 20. 
My very early years at Waipapa are unclear. By 1936, when my sister, aged six years, was to start school, we had moved to our father's elevated land beside the railway line on the outskirts of the PekaPeka block of semi-urban Waitara. ${ }^{129}$ The move was advantageous to us because of proximity to school, easy access to shops and businesses, and a wider range of other people with whom to interact. Our father's work place and everything we needed was within walking or cycling distance. The freezing works, blacksmith, police station, fire station, wharves, second-hand auction rooms, rowing club hall, fish and chip shop, three hotels and a billiard saloon for men only, picture theatre and four old houses were located on the industrial west river bank. The main shopping area provided a variety of business services, such as haberdashery, women's clothing, furniture and bedding, bicycles, Chinese fruiterer, Jewish men's outfitters, men's tailor, two grocers, a general store and two tea rooms. Our mother always stopped before shopping at Beckbessinger's General Store to converse in Te Reo Maori with the old ladies in their black dresses and head scarves sitting on the doorstep, smoking pipes of raurau, Maori tobacco, that they grew and cured themselves. There were garages and petrol stations, stock and station agents, post office, Plunket rooms, a library, doctor, dentist, accountants, solicitors, two banks, public toilets, convent and public primary schools, as well as four churches.

THE RAILWAY

The railway was a major part of our lives. The line between Waitara and New Plymouth was the first rail link in Taranaki. At the champagne opening in 1875, there was a special train of one decorated carriage for officials and guests plus two carriages for others. ${ }^{130}$ From the freezing works, the line curved around our urupa, ${ }^{131}$ up a long slope and on to Lepperton Junction to connect with the New

129 Waitangi Tribunal (1996), pp. 57-82.

130 Alexander (1970), p.39.

131 McGavin, T.A. (1976). A Century of Railways in Taranaki. Wellington: New Zealand Railway and Locomotive Society Inc. On p. 13 there is a photograph from the New Zealand Railway Observer, No. 142 (Vol 32, No. 2, 1975), showing, on the middle left, the back of our house, washing on the clothes line, and the train going round the elevated urupa in the foreground. 
Plymouth and the main trunk Auckland to Wellington lines. In 1876 an unsuccessful petition to stop Sunday passenger trains was presented to the government.

The trains from Waitara to Lepperton were discontinued by 1950, and passenger buses were used for main line connections at Lepperton. In 1950 and 1951, I travelled on the Waitara bus to Lepperton, main trunk line to Wellington, overnight ferry to Lyttelton, and train link to Christchurch to get to Teachers' College.

\section{The Waitara to New Plymouth Track Construction and Carolyn Perrott's} KIDNAPPING

Caroline Perrott told the full story of her 1874 kidnapping, during the construction of the New Plymouth to Waitara track, in an exclusive interview published in the magazine section of The Sun, Auckland, on 27 July 1929.132 Briefly, the railway line was planned to go through a burial ground of Maori killed during the 1860 land wars. William Perrott, a Maori-speaking resident of Lepperton, was contracted to remove the remains. Local Maori reminded him of the meaning of 'tapu' and his understanding of Maori ways, but William Perrott ignored them. In January 1874, when Perrott was out on another contract, his seven-year-old daughter Caroline disappeared. No trace of her was found until July 1929, when she was recognised by one of her sisters in Taneatua, a Bay of Plenty town. Caroline had been brought up by Maori as Sarah, and even though her life had been very hard, she chose to stay with them. Thelma Holyoake, the Infant Mistress, told me the same story when I was on the staff at Ruatoki District High School in 1952. She had first heard Caroline's story while teaching at Huirangi School near Lepperton.

\section{RAILWAY PEOPLE}

The author Janet Frame's family were 'railway people', who moved from town to town living in railway houses. She writes of shifting into a house:

132 The story is retold in McGregor, M. (1975). Petticoat Pioneers: North Island Women of the Colonial Era, Book Two. Wellington: A. H. and A. W. Reed, pp. 151-160. 
Beside the railway line and the goods shed and the engine shed and the turntable and the points and the water-tank painted railway hut red on its railway-hut-red stand beside the railway line and the spindly red painted little house high up where the signalman lived and hung out his signals and resting or retired railway carriages and trucks and trolleys. ${ }^{133}$

Her description is similar to the Waitara Railway Station and shunting yards not far from our home. The Waitara Station Master lived in a railway house too. The rhythmic sounds of wheels on iron rails as the trains and jiggers passed up and down the line between the freezing works and New Plymouth are embedded in my memory. Unlike Janet Frame, we collected coal fallen from the trains to supplement our fuel supplies; picked watercress, a staple food, under the willows beside the railway lines; crossed the train lines, 'played' giant strides across the sleepers as we walked to or from school, or tried to race beside the train. Our father maintained the long walking track between the railway line and the swamp. The track veered away from the railway line, crossed a wooden footbridge over a drain and curved up to our simple weathered red-roofed wooden house atop the hill. Our mother dragged prams, pushchairs, tricycles and us, while our father trundled a wheelbarrow loaded with bags of flour, sugar, groceries, forty pound cases of apples, firewood, and one hundredweight sacks of coal along the track up to our house. We chattered, argued and laughed, 'playing' out our dialogic encounters.

Brilliant spring and summer colours of yellow marigolds, shocking pink pelargoniums, red geraniums and purple violets massed around our house beside beaten earth paths and the huge well-kept lawn where our mother introduced us to 'playing' tennis. Miria remembers violets galore growing in her mother's home garden, to go and pick on Saturday morning to make a posy for her mother to wear to town. ${ }^{134}$ A long clothes line stretched across our backyard. A thick very high hedge protected the house and a lemon tree from winter elements, creating a barrier between our vigorous physical 'play' and the potato garden. Golden flowering gorse, long grass and a tangle of blackberry grew down the front slope to the swamp. Wooden fretwork adorned the top of our veranda. Wide wooden steps, where we

133 Frame, J. (1982). To the Is-land. New York: George Braziller, p.17.

134 Taylor (1994), p. 248. 
'played' jumping games, led to the front doorway flanked by tall narrow pink flowered glass windows. All footwear was left at the door. We children, girls in one boys in the other, 'shared beds'135 in two bedrooms; our parents and the baby in a crib or cot shared the parlour-converted third bedroom. The hub of our lives was the big cosy kitchen with a polished linoleum covered floor, sticky fly papers hanging from the ceiling, and the big kitchen table with a wooden form for us to sit on against the wall. Our mother scrubbed floors every day on her hands and knees, then emptied the water over the lemon tree as disease protection. Cleaning utensils and materials were used only for floor cleaning. Sometimes we dragged each other around on old clothes or clean sacks in polishing 'play'.

On reflection, our mother was an extraordinary woman and a life-long teetotaller who physically worked very hard. We were warm, clean, well fed, comfortable, secure and loved within the unshakeable enduring boundaries she set in our home. Of course we pushed those boundaries in childish encounters of defiance, squabbling, sulking, and crying. We knew what was expected of us, eventually sorted ourselves out and did as we were told. We were actually convinced that our mother could do anything and everything.

\section{Home AMENITIES}

Our mother was a personal cleanliness and hygiene fanatic. There was no indoor plumbing. In summer, water conservation was really important. She carried all water she needed from an outside tap connected to the town water supply or two huge rainwater tanks. We bathed, girls first then boys, in a large tin tub in the back door entrance area but in winter, in the kitchen warmth. We brushed our teeth with salt and water over a bucket. Our sewage system was a chamber pot at night and during the day, a north facing long drop, outside toilet, similar to Janet Frame's 'dumpy hole', ${ }^{136}$ some distance from the house.

135 See Penetito recollections in Bird, L. and Drewery, W. (2003). Human Development In Aotearoa: A Journey Through Life. Auckland: McGraw-Hill NZ, p. 53.

136 Frame, J. (1982), p. 29. 
For many years we did not have electricity, but used kerosene lamps that sometimes smoked. We carried candles to light us to bed. More importantly, we were careful learning to keep ourselves safe. Other people had electricity and the conveniences that it provided but as children we were not concerned that we seemed to live differently. We were not the only ones without electricity. I remember using our mother's sewing machine as a desk to complete my shorthand homework by lamplight in 1945.

The wood and coal kitchen range was in constant use for cooking and heating. Our refrigerator was a small wall safe on the cold side of the house. There was no telephone, radio, television, gramophone, or record player. I repeat, we devised our own amusements. After electricity was connected we had lights and a radio. I remember our father helping to erect the huge radio aerial with Stan Claire, the local wireless expert, the thrumming of wind songs through the aerial wires and the pleasure of turning on the lights and radio. Our mother listened to 'Aunt Daisy', our father to horse racing, we children to Uncle Tom and the Sancty Singers. ${ }^{137}$ Everyone listened to music and war news. Our mother did not have a washing machine, clothes drier, electric stove, refrigerator, proper bathroom or hot and cold running water until about 1952,138 when our dilapidated old house was demolished and we all moved to a larger house nearby, at the end of the track where the bags of wood and coal were left.

\section{Our Clothing}

Using her excellent seamstress and handcraft skills, our mother made most of our clothes, tea towels, envelope pillowcases and sheets on her Singer treadle sewing machine. Clothes were made to last, fitted properly, cared for meticulously and

137 'Aunt Daisy', Maud Basham (1879-1963), was a renowned broadcaster, best known for the morning session for women she ran on commercial station 1ZB from 1933 to 1963. See https://teara.govt.nz/en/biographies/4b11/basham-maud-ruby Thomas Threader Garland (1877-1964) broadcast weekly children's sessions for Radio 1ZR under the name, 'Uncle Tom'. See http://www.teara.govt.nz/en/biographies/4g6/garland-thomas-threader

138 Connor (1992, p.72) states that this would have been unusual at that time, since Electric Boards were set up in 1918, and most families in the Egmont area had fridges and electric stoves by the 1930s. 
mended as necessary. Dressed for all weathers in old dungarees, hat and coat, our mother hand-washed clothes and bed linen in tin tubs outside and then dried and aired everything in the sun or on the rack over the kitchen range. There always seemed to be nappies. I remember her washing was as white as the snow on Taranaki. We girls were taught her laundering techniques at a very early age. Most importantly was to never, ever, during the washing process, contaminate any items used for food with any items used for the body.

The flat irons that sat on the wood and coal range by the big black iron kettle, which I still have, were used to press our garments. Our mother, like many others, knitted, crocheted, smocked and embroidered our clothing. Miria, too, remembers her grandmother's 'colourful hand-crocheted wool petticoats.' ${ }^{139}$ As we grew older we watched, listened and through imitation 'play' absorbed those same skills with some success. We wore purpose made 'play', home, tide, school and best going out clothes. The boys wore pants or overalls bought or cut down from our father's worn saddle tweed trousers. Used buttons and elastic were hoarded, socks and woollens darned, shirt collars turned, buttons replaced and torn garments mended. Clothing was repaired, re-cut, remade, and if too small but still wearable, handed on to cousins on the farm, indicative of the hard wearing nature of the fabrics used, as well as their care and maintenance. Our shoes, gumboots, and rain coats, bought locally, were similarly redistributed. Everyone was poor, so we were not stigmatised. Everyone concentrated on enduring until the war was over, when we would resume a normal lifestyle.

My reflections are of growing up in a simple ordinary house, holidays on the Motunui farm or visiting with our cousins in Waitara, the sound of trains rushing past by day and sometimes night, and the constant chatter of dialogic encounters as we 'played', or were instructed, during the hustle and bustle of our daily activities. Our mother's domestication focussed life carried on every day and often at night during her quiet time, while we slept. As for many of her contemporaries, her family knowledge, personal skills and physical stamina were drawn upon. We did not feel deprived in any way; rather, my childhood memories are of strong behavioural boundaries,

139 Taylor and Morris Matthews (2016), p. 239. 
expectations and consequences. They were happy times of positive Maori/Pakeha experiences, healthy food, learning opportunities and the normal physical punishment of the time as our mother thought necessary. We knew who we were and to whom we were connected. People talked to us and we talked to them. Recycling was essential. Nothing was wasted. We learned valuable lessons in practical situations through dialogue and routines for economising and conserving resources.

\section{FoOD AND PLANTING}

Various varieties of potato - Maori Chief, Arron Banner, Sutton Supreme and the local Taewa, Maori potatoes ${ }^{140}$ - were dietary staples. A plough horse came from the Teira farm at Waipapa. Our father ploughed and our mother followed, spreading fertiliser and seed potatoes. The horse was returned. Later, under our mother's supervision, we participated enthusiastically, working up healthy appetites 'playing' at helping her hoe, weed, and bank the growing potatoes. The young puha, sow thistle, and poroporo, nightshade, flourishing amongst the potato rows, were picked, washed and rubbed vigorously to release the bitter sap in preparation for a dish we called 'the pot', a mix of meat, greens and root vegetables. When the leafy tops had dried our mother and father dug the potatoes, putting blemished tubers into loosely woven flax kits for immediate use. The smallest and sweetest were eaten next. The remainder were gathered and stored in a pit lined and covered with dry bracken fern, clean sacks and soil, for later bagging and storage in the shed with the matured kamokamo, Maori marrow. Tall Maori corn grew alongside the potatoes, protecting the new shoots emerging out of the soil from prevailing wind damage. Ashes from the kitchen fire were also strewn around the edges of the garden to deter feasting slugs and bugs. A long high bean fence supported heavy continuous crops of scarlet runner beans, and soapy dish washing water was flung over the bean plants to discourage similar predators. Selected taewa, potato, corn, kamokamo and beans were saved for the next year's seed.

\footnotetext{
140 Roskruge, N. (1999). Taewa Maori: Research Report. Palmerston North: Massey University.
} 
Kau, Cow, our jersey house cow grazing or chewing her cud in the paddock, provided milk products vital to our health. Twice a day, in all weathers, clad in old hat, coat, dungarees and gumboots, our mother went to the paddock with two clean buckets, one for milk, the other with warm water, a cloth to wash the cow's teats and Vaseline for teat damage. She called, 'Kau! Here Kau! Come on Kau!' Head up, big dewy eyes staring, dewlaps quivering, saliva dribbling, blaring forth, tight, swollen udder swinging, Kau advanced. As our mother milked, she talked to Kau. Sometimes we were allowed to drink squirts of the frothy, warm milk during milking out in the paddock. The creamy milk was later scalded in the big preserving pan, placed in the cold kitchen/utility room to cool and covered with a clean tea towel used only for that purpose. Thick cream rose to the surface ready for our porridge, puddings, bread and plum jam, or kaanga wai, 'preserved Maori corn'.141 Left over sour cream was hand-beaten into butter. It was not unusual to have a house cow if a family also had grazing. A local town milk run was operated as well and families left a billy out for the milkman. One of my brothers worked on the milk run while going to primary school.

Our mother was a superb plain cook. She used her black notebook of tried recipes, Aunt Daisy's Book of Handy Hints and Recipes, and the Edmonds Cookbook, all now resting on my bookshelves. She provided a wealth of scones, breads, chocolate and coconut cakes baked in the meat dish, biscuits, jams, chutneys, pickles and many tasty nutritious meals from a few ingredients measured by handful, jug, cup, spoon and eye, using minimal utensils. Foam biscuits and sultana buns were tasty snacks. I remember the pastry or sponge topped pies she made using meat, juicy blackberries we picked, apples, or other over-ripe fruit. Stew and dumplings and curried sausages were winter favourites, as was the pot of thick bubbling soup of meat bones and vegetables. Eggs, green gooseberries, apples, pears and plums were bought or exchanged from neighbours and relatives. I also remember being allowed to make the birthday sponge cake, beating endlessly with a broken three pronged fork. The freezing works provided meat; the garden, vegetables and some greens; the river, whitebait, herring and 'piharau, blind lamprey eels'. ${ }^{142}$ I remember

\footnotetext{
141 Burton (1982), p.15.

142 Bird and Drewery (2000), p.58.
} 
breathing the smoky, appetising aroma of the pink fleshed piharau barbecued on chicken wire over red hot coals in the back yard. The sea supplied shellfish, pipi, mussels, kina, sea urchins, or paua, according to moons and tides. Pipi were washed and steamed, and mussels scrubbed, eaten raw from the shell or steeped in vinegar and onions, steamed, fried whole or minced for fritters. Paua teeth were removed, the foot scraped, hammered, washed and braised with onions or minced and frittered. Kina were soaked in cold water to remove salt and eaten uncooked out of the shell on the second or third day after gathering. Crushed shells and soaking water were strewn around the lemon tree, adding lime and minerals to the soil.

As we grew older and could look after ourselves, we wore our old home and tide clothes for gathering foods. We followed strict, easy to understand, common sense guidelines. The sea was an important food source and as such always treated with respect. Full and new moon tides, such as lowest Spring tide, and seasonal harvesting were integral to the gathering. Our father gathered seafood but our mother stayed at home with us, so we did not experience group mataitai, seafood, gatherings or the collective dialogic encounters of that activity.

Reflecting upon our foods, we took for granted that some were a positive statement of our Te Atiawa Iwi Maori identity, for example, mataitai, shellfish; fish and whitebait; kaanga pirau, preserved corn; takakau, big round cartwheel scone bread, introduced through Pakeha adaptation; 143 piharau, blind lamprey eels; 'the pot' and soup resulting from cooking meat, greens such as cabbage, watercress or puha, sow thistle, and vegetables together. Penetito states, 'Kai Maori should be eaten with the fingers', ${ }^{144}$ and we often did. We did not eat karengo, seaweed, possibly because fish and shellfish were more readily available. Of major importance were clean food sources and specific hygiene practices for food gathering, preparation and conservation. Maori food rituals for harvesting, sharing and cooking were learnt very early. Pakeha ingredients were bought from the grocer's. We were a well nourished healthy brood as a result of common sense and a simple, nutritious, mostly home-grown diet. Our mother also believed in the positive effects of running

\footnotetext{
143 Burton (1982), p.15.

144 Bird and Drewery (2000), p. 58.
} 
around and 'playing' in the sun. Like Janet Frame's mother, 'An evident believer in 'inner cleanliness', our mother gave us 'regular doses of castor oil', 145 as well as Califig and Lane's Emulsion, with a quarter of an orange, boiled lolly, or spoon of Maltexo to follow. Childhood coughs were treated with hot lemon and honey drinks, and our chests and backs rubbed with Vicks Vaporub. Other necessary lotions, potions and ointments were bought from the travelling Rawleigh's salesman as required.

At Christmas coloured paper streamers and a huge bell decorated the kitchen. Stuffed colonial goose, roast pork, and poultry were prepared and put in the oven very early on Christmas morning. The ham and Christmas pudding, wrapped in its special cloth, bubbled in heavy enamelled iron pots on the stove. The boys 'played' carrying wood for our mother to stoke the fire. We girls 'played' scraping new potatoes, shelling peas, stirring mint sauce, apple sauce, thick rich gravy, custard, and whipped cream. Mother's Christmas cake, made well in advance, sat on a special Victorian glass stand. On birthdays we helped decorate the cake with whipped cream, hundreds and thousands and candles. We set the table with our mother's best white starched damask table cloth, crockery and cutlery. After eating our meat and vegetables we had trifle, bananas set in jelly, lollies, iced animal biscuits and fruit.

Sometimes the celebration was our birthday present. Handed down clothing, tricycles or bicycles were also Christmas or birthday presents. When we were older we often rode our bikes five miles out to the farm and back. Sometimes we rode on the back of the farm truck and made silly faces in the wind. I do not remember any restrictions about carrying people on truck trays then. Our father mended the punctures and cleaned and oiled our bikes until we could do them ourselves. Serious problems were repaired at the local cycle and mower shop. Bicycles were a popular form of transport for people who could not afford to buy cars. We also had fun lighting crackers safely in the back yard on Guy Fawkes night under our mother's watchful eyes.

145 Frame (1982), p. 21. 
Reflecting upon how we lived as Maori/Pakeha cultural navigators, drawing on both Maori and English cultural capital, we 'became adept at moving through various socio-cultural settings'.146 We unconsciously developed facets of resilience and endurance through exposure to people around us and the learning opportunities their proximity offered to us. My interviewee Yvonne recalls Te Rangi Hiroa Sir Peter Buck saying to her, 'Never forget that you're a very fortunate child because you have two choices, you choose whether to be Maori or European. Sometimes remember that a blend of the both is better.'147 We absorbed appropriate behaviours at Maori and Pakeha cultural interfaces, spontaneously mixing Maori and Pakeha traits, switching easily between cultures, unconsciously blending as we internalised behaviours expected by our parents. I do not recall ever deliberating upon, or choosing, what degree of Maori or Pakeha cultural behaviours I operated in, because the mix was spontaneous and governed by the situation. I just knew. Similarly, Miria mixed Maori/English in bilingualism, stating, 'I don't ever remember having to learn either language, Maori or English, you just know.' 148

As I reflected upon growing up our pre-school education was 'played out' at home in dialogic encounters during 'play' as fun work with our Mother and siblings in practical baby care, home craft, responsibilities and general lifestyle 'play'. From this family environment of negotiating spaces of freedom, and home based preschool cultural capital 'play' towards resilience and endurance, I entered primary school negotiation spaces for the next stage of my learning 'play'.

\section{PRIMARY SCHOOL YEARS}

Waitara West School was built in 1884 for one hundred children. By the 1940s, the school's name had been changed four times to become Waitara District Primary School, a large full primary school from Primer One to Standard Six, or Form Two, as there was no Intermediate School at that time. ${ }^{149}$ All children were

\footnotetext{
146 Carter, P.L. (2010). Race and Cultural Flexibility among Students in Different Multiracial Schools. Teachers College Record, 112(6), 1529-1574, http://dx.doi.org/

147 Taylor and Morris Matthews (2016), p. 230.

148 Taylor and Morris Matthews (2016), p. 239.

149 Waitara Central School Jubilee Committee (1975). Waitara Central School Centenary, 1875-1975: Souvenir Booklet, $16^{\text {th }}, 17^{\text {th }}$, 18 ${ }^{\text {th }}$ May. Waitara: Jubilee Committee.
} 
mainstreamed. Those with vision, hearing, or learning impairments, physical disability, and the gifted were in the same classes. Parent help was not part of the everyday school scene. There were ten classrooms in three separate blocks. Rooms for Cooking and Woodwork, and a Dental Clinic, also used by other schools, as well as the flagpole, were grouped together. We had extensive sealed and grassed areas for 'play'; shelter and bicycle sheds; a spring diving board, and a swimming pool 25 yards long and 3-6 feet deep. School vegetable garden plots were sited behind the change rooms. Visiting Science Advisers came to demonstrate composting, preparing gardens for planting and care of plants. In Standards Five and Six we were encouraged to propagate seeds bought at school for home garden plots, to be judged later in the year for the awarding of certificates. In Nature Study we learnt about native trees in the small school bush area, which was otherwise out of bounds. I recall drying leaves in between newspaper under the floor mats at home and then carefully mounting and labelling them appropriately in a book.

In 1936, after the Depression, 'five-year-olds were readmitted to school ... despite shortages of both teachers and buildings'.150 Teachers were discussing the introduction of 'activity period work' in infant classes and psychologist/paediatrician Arnold Gesell's scientific and theoretical approach to 'the idea of a child's psychological 'readiness' for learning'. 151 'In the same way that "play" was considered to be central to a child's learning and development, the idea of 'understanding' children became a core element of progressive education pedagogy.'152

It was into this educational change space, after my fifth birthday in 1937, that I, Kura Taylor, unknowingly left my Maori self at home and taking my Pakeha self, trailed after my sister to Waitara Public School and Miss Burnett, my first teacher. I had my named school bag and old sock blackboard duster, made by our mother. My lunch was in a brown paper bag, crumbs to be shaken out, bag folded and taken home for reuse. Our mother had taught me the alphabet, counting to ten, and how to write

150 May, H. (2011). 'I am five and I go to school': Early Years Schooling in New Zealand, 1900-2010. Dunedin: Otago University Press, p.102.

${ }^{151}$ May (2011), pp. 129, 131.

152 May (2011), p. 134. 
my name during our pre-school dialogic encounters. Like her father and grandfather, I was English speaking. Wet or fine, our way to or from school was such fun, a negotiating space chosen for whom we would meet, the physical enjoyment of hop scotch, climbing willow trees, sloshing in drains, and a wonderful culvert that echoed to our screaming and yelling.

SCHOOL MILK

In 1937 a free school milk scheme was introduced by the Labour Government, concerned with improving children's health while the country was recovering from the Depression. ${ }^{153}$ Crates of milk, and, in April 1941, the first boxes of free apples, were accordingly delivered. ${ }^{154}$ We then had a half-pint bottle of milk and an apple each day. School milk made some children really ill, so the milk monitors often drank two bottles. The free milk scheme was discontinued in 1967.

My earliest recollections of Waitara School are the stench exuded by a mix of sour milk and oiled floors; wet raincoats and smelly gumboots; smoke from winter fires; toilets sheltered by thick high hedges away across the playground; and the voices of many children. Miss Burnett introduced me to the children, and I was shown my coat and named school bag peg, hand basins and toilets. She called our names each morning and after lunch. We responded. She made marks in the register. We had a short rest and then she 'played' the piano while we sang nursery rhymes and other songs. We sat on the scratchy mats on oiled floors or on chairs at desks, reading, talking, counting, listening, stitching, printing and drawing on wall or individual blackboards. Miss Burnett read to us. We read to her. The only reading material we had at home was a seldom opened set of Bible stories, ${ }^{155}$ the Weekly News, and Jules Verne's Journey Into the Interior of the Earth, which I was given as a Sunday School prize for attendance. School was a world of serious 'play' and wide ranging

153 Ministry for Culture and Heritage (2017). 'End of free school milk'. https://nzhistory.govt.nz/end-of-free-school-milk Updated 12 April.

${ }_{154}$ Waitara Central School Jubilee Committee (1975).

155 Evans, A. B. (n.d.). Bible Pictures and Stories, Vol. One: Easy Steps in the Bible Story From Creation to Joseph; Vol. Two: The Children's Friend Pictures and Stories of Jesus; Vol. Three: Men of Might From Moses to Samuel; Vol. Four: Stories of the Kings From David to Christ. Warburton, VIC.: Signs Publishing Company. 
dialogic encounters with other children and teachers. I learnt to read from Whitcombe's Progressive Readers. ${ }^{156}$ Phonics, listed at the back of each book, were in vogue for decoding text and spelling. While our mother did not read to us, she made sure that we went through our reading, spelling and times tables homework every night. Homework was not negotiable in our house. I think this was the beginning of what was later to develop into my teacher and academic selves.

\section{GENERAL HEALTH}

The school doctor and district health nurse visited schools regularly to check our health and, with our parent's signed consent, vaccinated us. I recall having followup checks at school after my aunt died of tuberculosis in 1941. Armed with the finetoothed nit comb and newspaper to catch the offending eggs or lice, our mother also regularly sought 'the nits'. Scabies, hakihaki, school sores, or impetigo, were other distasteful school skin infections. I remember arriving home with highly infectious hakihaki. Our mother went berserk. Slathered in smelly khaki coloured 'sulphur ointment for hakihaki', ${ }^{157}$ dressed in my oldest clothes, I was kept home from school. I remember mother's long soliloquies about the state of my bed sheets and my clothes. She inspected us closely every day.

\section{Dental Health}

Dental clinic records for treatment show that 'extraction and fillings' were completed in 1926, and a new two-nurse clinic was officially opened in $1943.158 \mathrm{We}$ went regularly from class to see the Dental Nurse. Soon after I started school, she pulled out four of my molars and slapped me for crying. I remember going back to my class sobbing and snivelling, my mouth full of cotton wool. Miss Burnett comforted me, sent for my sister to take me home and sat me in the sun to wait. Fortunately, I did not develop a fear of dentists.

\footnotetext{
156 See Price, H. (1992). School Books Published in New Zealand to 1960. Palmerston North: Dunmore Press.

157 Simon, J. (Ed.) (1998). Ngā Kura Māori: The Native Schools System 1867-1969. Auckland: Auckland University Press, p. 128.

158 Waitara Central School Jubilee Committee (1975), p. 25.
} 
We were introduced to savings through the Post Office Savings Bank's School Savings Scheme. Every week a deposit slip and pink savings bank book were put into a bank cover and taken home. The next day teachers checked slips and money. A bank person collected all our books, totalled the deposits, put in a new deposit slip and returned our books to school. Once a year interest was assessed and entered. We were very proud of our efforts as our savings grew. I am often reminded of our mother regularly saying, "If you can't pay for it you don't have it!' We saved!

\section{Promotion to STANDARd ONE}

In 1939, after only one year and one term in the infant classes, I was promoted to Standard One. Why? Perhaps an early indication of my ability? I assume my promotion indicated my potential, but it was not discussed with my parents or me. This was to impact upon me into adulthood. I was just six years old, a year younger than everyone else, smallest in the class, labelled Baby and treated by my peers accordingly. In the standard classes I also became aware that our classes were of mixed ability and disability. Each day started with ten minutes of rote chanting multiplication tables, oral tests in mental arithmetic and spelling. Our teacher checked our marking of each other's work. Everyone knew the results and the consequences.

My Standard Two teacher was viewed by the community as a no-nonsense strict disciplinarian. Our classroom was tiered, double desks in rows with the teacher's table in front. She supervised us and dictated our weekly spelling tests, walking up and down the tiered aisles. She also expected us to listen and read aloud in turn every day. We read our School Journal159 standing with backs straight, heads up, clearly enunciating the words, our journals at a precise angle for our voices to flow over the top and be audible to everyone in the room without shouting. There was always some trepidation about reading aloud, but, when she called a name, that child

\footnotetext{
159 The first New Zealand School Journal was published on 9 May 1907. Still published today, it is believed to be the longest-running serial publication for children in the world.

https://nzhistory.govt.nz/first-school-journal-published
} 
stood and read. We listened. My friend Betty brought comics to school that we devoured avidly at lunch time. I remember Rockfist Rogan, ace pilot and boxer, who had really exciting flying adventures and always won his boxing matches.

Our teacher demanded we take pride in our cursive writing, and she randomly measured posture, body distance from paper, book and pencil angles with her ruler from our chins to our desks. We were told that if we sat and wrote as she taught us, later on we would be able to write for a long time and not get tired. Published Arithmetic, English Grammar and Comprehension Workbooks were used. I remember in Standard Three listening in awe to a Maori boy with an aptitude for numbers mentally and quickly add columns of figures, and subtract or multiply numbers. We learned a great deal about British history from Our Nation's Story,160 but very little New Zealand history. I remember token reference being made to Maori Chiefs such as Tamati Waka Nene (Tammatee Wocka NeeNee); Rewi Maniapoto (Reewee Manniahpoetoe); and Te Rauparaha (Tee Rowprahhah), their names pronounced very strangely even to my young Maori/Pakeha ear. We memorised poems such as Newbolt's 'Drake's Drum', Tennyson's 'The Charge of the Light Brigade' and Wordsworth's 'Daffodils'.

Corporal punishment and writing lines were disciplinary norms. Standards Two to Six were often composite classes, with physically large, strong pupils who were regularly strapped for misdemeanours at school or going to and from school. Jean recalled the 'stinging strap', Corporal punishment and writing lines were disciplinary norms. Standards Two to Six were often composite classes, with physically large strong pupils who were regularly strapped for misdemeanours at, or going to and from school. Jean recalled the 'stinging strap', as did Yvonne, who remembered that 'use of the strap was very prevalent in those days'. ${ }^{161}$

Music and Singing in Standard classes was taught through the School Radio Broadcast system, although we did have two male teachers who used radio and

160 Anonymous (n.d.). Our Nation's Story, A Course of British History, Britain's Primary History Series. London, Melbourne and Sydney: Whitcombe \& Tombs Ltd, NZ. See also Price (1992). The 'Nation' in the title was the British nation. 161 Taylor (1994), pp. 153, 212. 
'played' violin. We sang 'Po kare kare ana' (Poe carry carry ahnah) to violin accompaniment. Many families, including two of my aunts, had a piano at home and family sing-a-longs were part of their lives. My sister learnt piano from the nuns at the local convent. I did not. Easily transported instruments such as guitar, ukulele, mouth organ, comb and spoons were popular too. I envied Maori who 'played' instruments by ear. The Salvation Army regularly 'played' piano accordions and sang outside the shops. We paid sixpence to hear visiting musicians and singers after school. I remember pianist Cara Hall, who showed us the little hot water bottle she used to keep her hands warm inside a furry grey muff. We were fortunate to see and hear such artistes as actual people highly accomplished in their own cultural fields.

In Art we printed potato cut designs, drew trees and various other objects in pastel or pencil, created collage pictures, and produced watercolour paintings. Art was not one of my strengths. Craft was wool needlework on clean sugar bags, or pictures made from cut-out sticky coloured paper. We wound wool through the hole in cardboard milk tops to make pompoms, or, using a cotton reel and nails, we wove long woollen rat's tails in French knitting that we stitched into circular pot holders or doyleys.

We had three half-hour lessons of Physical Education every week. Boy monitors set out equipment and we went through routines of individual warming up and agility exercises, followed by ball handling, rope, balance bench, hoop and mat routines. Then we 'played' team games, ran relays and finished with warm-down exercises while the monitors returned the equipment to storage. At the summer athletic sports, on the grass 'playing' field, I remember competing in class relays, flat age races, three-legged, potato, egg and spoon, obstacle and sack races, some of which we practised during physical education lessons or at lunch times. In summer we swam. I remember the other children swimming past me as I clutched the side rail or sat on the steps of the bath until I learned to swim. Even though others bigger and stronger swam past me, I learned to perform an impressive forward pike dive off the 3-foot spring board. Every Saturday night the swimming bath was drained, cleaned and refilled. The school swimming sports marked the end of the swimming season. We were marched to allocated places on the tiered seating around the pool 
and closely supervised. Quiet reigned for the start of the races. Then we yelled and screamed lustily. The swimmers dripped their way back to wait for their next race or changed and joined their classes. After the swimming sports we were marched back to class in quiet orderly lines. I remember Duncan Laing's father running up and down one side of the swimming pool screaming and yelling while Duncan trained for competitions. I remember his long slow freestyle stroke and his kick that hardly broke water. We all tried to copy him in the other side of the pool with little success. The swimming bath was emptied and closed for the winter.

\section{THE FANCY DRESS BALL}

The School Fancy Dress Ball was a memorable, magical, family event held in the Anglican Church Hall. We promenaded in costumes, dressed up as clowns, firemen, nursery rhyme or fairy tale characters, in the ceremonial Grand March we had practised in the 'playground'. Once I went as Danger Signals in a red dress and hat that my mother made, covered with 'STOP' and similar signs. Our costumes were judged in classes. We danced the Grand Old Duke of York. Parents served supper with soft drinks in our own named mugs. We walked home happy and worn out to start school one hour later the next morning. For one short evening families were able to laugh and celebrate as a community the really good life we had, compared with others, because the war was so far away from us.

\section{TARANAKI CENTENNIAL}

In 1941, Taranaki Province celebrated its Centennial at Pukekura Park in New Plymouth. Primary schools were brought together for an organised display. Each school had practised creating a part of Taranaki Te Maunga, or Mt Egmont (as it was then known), and the centennial dates. ${ }^{162}$ We travelled by train to New Plymouth. All traffic was stopped while we proudly marched along the middle of the road with teachers and monitors to Pukekura Park and took our specified places on the terraces. Then the hours of practice by all schools came together in precise magnificent choreography. All schools combined their practised parts to music. We

162 Waitara Central School Jubilee Committee (1975), p.77. 
kneeled and bowed in salaam. The result was spectacular. We created our own snow-topped mountain and centennial dates on the green grass of the park. Everyone was ecstatic. I remember my feelings of being lost leaving the Park, carried along by the fast-moving crowd, bawling and bellowing in panic, my belongings abandoned. Then a hand reached out and grasped mine. A voice said, 'Here she is Sir. She's found!' My older cousin Betty Pennington gathered me in. She and her friends looked after me until the train arrived back in Waitara. It is very likely that experience was the birth of my unease in large crowds. I was pleased months later when my named belongings were returned to me intact at school, due to very good organisation by teachers throughout the Taranaki school system.

\section{WORLD WAR II}

This was the most significant world event influencing my schooling years. I was just seven years old when the enlistment of New Zealanders began on 12 September 1939, one week after the declaration of war. ${ }^{163}$ In 1921, weekly ceremonies to salute the flag became compulsory in public schools. The flag was flown every day. On Fridays the school assembled in front of the flagpole. We sang the national anthem, 'God Save the King'. On Anzac Day we were given printed paper poppy labels, had an appropriate flagpole ceremony and recited Rupert Brooke's poem, 'For the Fallen'. There were 15-20 trenches dug around the perimeter of the top playing field, for our protection, not for 'play', and we practised evacuation drills for orderly movement to our assigned trenches with older monitors. Throughout the war, photos of the men and women wounded, missing, or killed in action were published, for example in the Weekly News.

\section{OUR CONTRIBUtion to THE WAR EFForT}

We knitted warm balaclavas, gloves, mittens and scarves for the soldiers, sailors and airmen. Knitted or crocheted squares were stitched into knee rugs for the sick and wounded in hospitals or convalescing at home. Our Sunday School teacher, Molly

163 King, M. (1981). New Zealanders at War. Auckland: Heinemann, p. 168. 
Trim, distributed wool and collected our efforts. I remember knitting a neverending grey and black flecked wool scarf in garter stitch. It took a long time but I finished it. I wondered who wore my warm scarf. We collected precious grains of ergot for medical purposes from cocksfoot, rye and fescue grasses. Community Queen Carnivals and various regular ${ }^{164}$ local fund raising ventures were held for the duration of the war, with public notices on a huge community board giving the accumulating totals. The funds were donated to the Red Cross to send parcels to our servicemen. We felt so important.

\section{The Americans Arrive}

American Marines came to New Zealand on leave from the Pacific theatres of war. 'The presence of the marines - and their success with New Zealand women - was a source of abrasion with New Zealand servicemen and led to occasional brawls'.165 The Americans danced the energetic jive with our young women too. I remember one who stayed with a Waitara family. He came to our school in his smart uniform and spoke to us about his life before he enlisted. He told us of places and families from further away than most of us could imagine. The American Hollywood movie scene was more familiar to us through actors such as Clark Gable, Johnny Weismuller as Tarzan, swimmer Esther Williams, and ice skater Sonja Henie. There were child stars too: Bobby Breen, famous for singing 'Somewhere Over the Rainbow', Shirley Temple, the singer/dancer performing 'In the Good Ship Lollipop', Elizabeth Taylor and Roddy McDowell riding horses.

\section{Blackouts AND Community SingING}

The war years also brought blackouts. Our mother sewed heavy dark green fabric for our kitchen blackout blind, which she carefully rolled down at sunset and rolled up every morning. I remember our mother and our aunt taking me to community singing in the local Clifton Rowing Club hall. Words were projected on to a wall, someone 'played' the piano and everyone sang songs: We're Comin' in on a Wing and

\footnotetext{
164 King (1981), p. 253.

165 Bioletti, (1989), p. 77).
} 
a Prayer, Maori Battalion March to Victory, Lili Marlene, Keep the Home Fires Burning, and There'll Be Blue Birds Over the White Cliffs of Dover. Afterwards we all trudged home by starlight or in the dark. The fathers of some of my school friends enlisted for war service. Our father did not - I don't know why. He regularly wrote to a friend serving overseas. I remember the thick black censored lines across the letters he received. He had a cousin in the Air Force and one in the Maori Battalion. Other Waitara men formed the local Home Guard, 'made up largely of men too old to enlist in the armed forces'.166

\section{RATIONING}

The government introduced rationing in 1942. Small brown ration books were issued to families, registration with retailers was essential, and shopkeepers were required to cut coupons out of ration books for purchases - loose coupons were not accepted. The first thing to be rationed was petrol. 167 We had no vehicle, so were not affected, unlike my aunt and uncle at Motunui with two farm vehicles. I remember our mother carefully working out when she would have enough butter and sugar coupons to make the Christmas cake, who would have the next pair of shoes, or when she could buy new unbleached calico sheets. I also recall her taking me to the shoe shop to buy new shoes. The shopkeeper, Herb Billing, said, 'I'm sorry, Mrs Taylor. I don't have any shoes to fit her. The ship was sunk in the Atlantic. I don't know when there will be another ship with more shoes.'

Apart from news, espionage, resistance, and the concentration camp and holocaust films at the local theatre, my main memories of stretching our resources. Shortages were our way of life. At school we used both sides of every scrap of paper and the end of the year saved clean pages to use the next year. ${ }^{168}$ Reading books, drawing books, journal covers, pastels, pencils, pens, rubbers and rulers were all treated with similar care, to be passed on to younger siblings. The enlistment of young men caused a critical shortage of farm workers, so women took on men's roles as well as

\footnotetext{
166 King (1981), p. 247.

167 King (1981), p. 253. Connor (1992, p.73) records that after petrol was rationed in 1942 came sugar, in April; clothing, footwear and household linen, in May; tea, in June; and butter, in October 1943.

168 Montgomerie (2001), p. 13.
} 
their own, many becoming unwaged land girls seen as volunteers. ${ }^{169}$ Communities drew closer together, sharing information and resources, drawing on each other's strength and resilience to endure. We learnt an amazing range of life skills through cooperation and sharing as a consequence of the war impacting on our lifestyle.

VICTORY IN EUROPE

In May 1945, Victory in Europe (VE) Day was declared, with Germany's unconditional surrender, and in August came Victory over Japan (Vj) Day. 'Both brought tumultuous scenes of jubilation.'170 In Waitara, I recall, the freezing works whistle sounded, the fire siren wailed, school and church bells rang, car horns tooted. What a cacophony of happy sounds! Dressed in our best clothes, it seemed the whole of Waitara crowded along the main street in the shopping area celebrating. Wild with excitement we wore ourselves out laughing, hugging, cheering, throwing confetti, singing with Spanish and steel guitars dancing the conga in and out of the hotels, under the shop verandas, and generally blocking the street.

\section{SCHOOL FRIENDS}

Apart from my Maori and Maori/Pakeha cousins, my friends were all Pakeha, simply because we lived amongst them and they were dominant in my classes. We 'played' games like hide and seek, marbles, hopscotch, skipping, statues, 'What's the time Mr Wolf?' and rounders, at school as well as at home. Our friends were discouraged from visiting our home, probably because of differences in how we lived and some of the food we ate. We met at their homes or some appointed place, and as a group we walked or rode our bikes everywhere. We also met at Sunday School, Bible Class, Church Choir and Confirmation classes. We paid sixpence at the picture theatre on Saturday afternoons and had a penny ice cream at interval. We had Athletic Sports and Wood Chopping events at the Camp Reserve, swimming at the beach, and, as spectators, to rowing regattas held on the river. I vaguely remember dancing classes in the church hall and family celebrations in local halls, dancing the Gay Gordons, Valeta, Maxina, foxtrot, and quickstep, and waltzing with adults. I made lasting

169 Montgomerie (2001), p. 49.

170 King (1981), pp. 264-5. 
friends at primary school, some of whom I still intermittently telephone or correspond with.

Reflecting on my primary schooling years, I remember always being the youngest and smallest in my classes. I desperately wanted to learn the powerful underarm back flick 'played' in nine-a-side basketball by the bigger Maori girls, but I was too young. Instead, with my friend Betty, we took the only alternative - an elocution class taught by Miss Hoben, who travelled from New Plymouth on Saturdays. (Sonja Davies recalls being taught elocution by her grandmother.) ${ }^{171}$ I remember being Dormouse in an Alice in Wonderland play for a Plunket fundraising venture. In the finale I was stuffed head first into a huge teapot. I thought it was just as well my mother was not there to see that! Heads did not go into teapots!

\section{BOREDOM?}

In Standard Four I was required to repeat my writing for homework and was sent to a woman teacher to be strapped. My sister, who was in her class, was given the option to leave the room while I was being disciplined, but declined. My writing deteriorated more and more with repetition, my stoic defiance, and passive resistance. Finally we reached a truce and I produced what I knew I could do well. Perhaps I was bored. I did not do well in a scholarship examination for high school either. I remember that questions about the war dominated the examination paper. No teacher stands out as inspirational. I do not recall my parents ever being personally advised about my progress or my potential. In the 1970s, a friend said his mother had been told by our teacher that I 'was the brightest kid to have come into the school for years'.172 I put in enough effort to stay within my class group, and in 1944 achieved a Primary Proficiency Certificate. The physical, social and emotional effects of immaturity were to have ramifications for me throughout high school.

\footnotetext{
171 Davies (1997), p.13.

172 B. Henderson, personal communication, 1970 s.
} 
On reflection, despite the ups and downs, I enjoyed my primary school years as I wandered through doing what was necessary. It was a place of English language and behaviours. Teachers were to be tolerated. If we were strapped at school we were delivered a repeat at home, because we went to school to learn and obviously had not been listening to the teacher. Being already exposed to colonial ways and English speaking, I knew acceptable Pakeha behavioural boundaries. I had no great problem fitting into the school system that crafted me into an assimilated, integrated, hegemonised brown Pakeha, ready for the completely different increasingly sophisticated 'play' of secondary school.

\section{SECONDARY SCHOOL YEARS}

'The push for all avenues of access to education to be open to women came initially from a constituency of voting parents which, from 1893, included women themselves ... Access to fee-charging (but publicly endowed) secondary schools was viewed as a middle-class prerogative.'173 In 1939 Clarence Beeby, the newly appointed Assistant Director of Education, interpreted and drafted a new policy education statement for the then Prime Minister, Peter Fraser:

The government's objective, broadly expressed, is that every person, whatever his level of academic ability, whether he be rich or poor, whether he live in town or country, has a right, as a citizen, to a free education of the kind for which he is best fitted, and to the fullest extent of his powers. So far is this from being a pious platitude that the full acceptance of the principle will involve the reorientation of the whole education system. ${ }^{174}$

Even though I was not a 'he' or a 'his', this 'equality of opportunity' policy statement was to impact upon my secondary schooling at New Plymouth Girls' High, during teacher training, and in my teaching years. In 1940 Clarence Beeby became Director of Education, to put in place wide reaching national changes in the delivery of education and 'to design a programme of school reform geared towards realising

173 Morris Matthews, K. (2008). In Their Own Right: Women and Higher Education in New Zealand Before 1945. Wellington: NZCER Press, pp. 11, 12.

174 Beeby, C. E. (1992). Biography Of An Idea: Beeby On Education. Wellington: New Zealand Council for Educational Research, p. xvi. 
progressive education ideals'. ${ }^{175}$ In 1943 the government-appointed members of the Thomas Committee released their report recommending changes to regulations to bring in a secondary curriculum of core subjects, with compulsory English and a minimum of three other academic or vocational subjects for national examination. In 1946 a new School Certificate Examination was introduced under The Education (Post-Primary Instruction) Regulations 1945.176

In 1945, from the co-educational Waitara District Primary School, I was enrolled in the only readily accessible secondary school near Waitara, the completely different single-sex New Plymouth Girls' High School, which I could attend as a day girl. New Plymouth High School had originally opened in 1882 as a fee-paying school for boys. In 1885, 26 girls were admitted. In 1913 the girls were moved off-site and a separate New Plymouth Girls' High School was established, with provision for five boarders. In 1926 the two schools and New Plymouth Technical School were amalgamated.177

My new school was an educational institution with high performance expectations and a strict dress and hair code, as befitted young Pakeha ladies. The school occupied an elevated position at the top of a steep bush clad bank in a bend of the Te Henui River. City streets and residential sections defined the other boundaries. The main two-storey school building, in red brick, housed offices, staffroom, classrooms, cloakrooms and toilets. A huge flat playing field, and sealed tennis and basketball courts, separated a single-storey roughcast building, housing a library, classrooms, science laboratory, prefects' room, cloakrooms and toilets, from the brick building. The separate building of Scotlands provided residential facilities for the Head Mistress and the rural girls who boarded. There were also two separate prefabricated classrooms, music, art and cooking rooms, and a large gymnasium where assemblies were held. Our mother's sister had been sent to Queen Victoria School for Maori Girls in Auckland at the age of six, and I suspect this was why she would not hear of us going away to any boarding school. Her stepmother would not

\footnotetext{
175 May (2011), p. 123.

176 Beeby (1992), pp. 161-201.

177 Cole Catley, C. (1985). Springboard For Women: New Plymouth Girls' High School 1885-1985. Queen Charlotte Sound, NZ: Cape Catley, pp. 12-16.
} 
have her sister in the house, because of her very fair skin and auburn hair. She looked like a Pakeha, but she and her fair children always claimed Maori identity.

BUS GIRLS

School buses were an important part of the Labour Government's education policy. A network of buses was introduced to make further education possible for country pupils whose parents could not afford to send them to boarding school or have them board in a town. I became a bus-girl like my older sister. We arrived at school after morning assembly had started, and were required to enter quietly by the back door of the gym, in full view of staff on the stage. As bus girls, we were treated disdainfully by many teachers and girls. The bus left immediately after school, preventing us from participating in any extra-curricular activities. ${ }^{178}$

\section{NURSE, TEACHER OR SECRETARY}

I was twelve years old, a little brown Maori/Pakeha thrust into a totally different learning environment, during the last year of World War II. I had three upwardly mobile employment choices: nurse, teacher, or secretary. I spent my third, fourth and fifth form years as the only Maori/Pakeha in small, low status Commercial Course Special Classes. I chose to think they were labeled 'Special' because we were fast learners, but perhaps I was there to balance class sizes because of the number of girls taking Commercial. Most Maori girls were in the Domestic Course. I recall only one being in the high status Academic Course. My parents paid for the required textbooks, stationery pens and pencils, available from the school Book Room. Maori were invisible until we were paraded to entertain at a school concert. I stayed with a Pakeha friend in New Plymouth that night, because I had no way of getting home afterwards. I remember that concert with real sadness, because I wore Granny's black-tasselled korowai, cloak. Unfortunately, when we were changing after the performance, the cloak disappeared, never to be found or returned. ${ }^{179}$ After the concert, Maori went back into the shadows. Seen through adolescent eyes,

\footnotetext{
178 Cole Catley (1985), p. 122.
}

179 Cole Catley (1985), p.142. 
surrounded by the fruits of excellence recorded as achievements in the Sciences, Languages, Music, and Arts, my Pakeha school learning environment was distinctly Pakeha regulated and Pakeha rule bound.

\section{TEACHERS AND UNIFORMS}

Most teachers wore academic gowns that billowed like the sails of a ship as they promenaded across the grounds and along corridors. Sonja Davies remembers the principal who 'strode through the corridors wearing a rusty black gown for all the world like some large bird.'180 The school enforced regular inspections of summer and winter dress codes, including monogrammed school blazers, navy blue berets in winter, adorned with a silver school hat badge, long black woollen stockings and black shoes. The gym tunics had three box pleats front and back, with an inside domed front yoke pocket for our personal items and money, just touching the floor when kneeling. Beneath them we wore a long-sleeved white shirt blouse, with a school tie and gym girdle properly slip knotted. Each night the gym tunic was placed under the mattress between newspaper to keep the pleats pressed, and in the weekends it was sponged with cold tea to remove the shine from sitting. Yvonne recalled, 'my uniform was a constant source of adolescent embarrassment because it was always third or fourth-hand. It was always old and shiny.'181 Hair was above the collar or tied back with a navy blue ribbon. No signet rings or fancy hairclips, only a coloured sports house button and a prefect's badge, pinned to gym tunic yokes. Summer uniform included a panama hat with silver badge, button-to-neck short-sleeved blouse with peterpan collar, no tie, black or navy ankle socks and black shoes, or Roman sandals without socks. We wore navy blue school rompers or black Italian cloth bloomers, detested by our mother, for physical education.

\section{BLUEPRINT FOR OUR FUTURE}

Reflecting on high school, I see it as a Pakeha feminist institution that provided Pakeha classist models of Pakeha decorum and modesty. The blueprint for our future emphasised pride in school, standards of work, behaviour becoming Pakeha

\footnotetext{
180 Davies (1984), p. 23.

181 Taylor (1994), p. 206.
} 
young ladies, remembering one's place as woman was inferior to man, and Maori were their cleaning persons. When Miria returned to Whakatane High School after a long sickness and was steered towards the Domestic Course, she stated, 'I have no wish to be somebody's housemaid.'182 She was determined to enrol in the Commercial Course. Miria later became a medical receptionist and a university librarian.

At New Plymouth Girls' High School English was a compulsory core subject, reinforcing the formal rules of grammar, sentence structure, spelling and punctuation necessary for my future destiny as an office administrator. We were also led through the literary works of, for example, Shakespeare, Louisa Alcott and Jane Austen. I remember telling my parents that my class was speaking about going to the Boys' High School to begin accountancy, and then on to university for a Bachelor of Commerce degree. My father very firmly said, 'Maori girls don't go up there to that other school chasing around after boys and they don't go to that university place. They stay at school and then go out and get a decent job!' I learnt Pitman's Shorthand and accurate speed touch typing, using an apron to cover and memorise the keyboard of a manual typewriter. We were taught how to choose, mark off passages in Hansard's Parliamentary Debates, and dictate at speeds of 50 to 120 words per minute, using a stop watch. Book-keeping was not one of my greatest accomplishments. I remember little of Commercial Practice except how to fill in a bank cheque.

I really enjoyed Physical Education, swimming and springboard diving. We could not afford to buy swimsuits, and elastic was in very short supply. So I designed and made my own lined, fitted and laced up one and two-piece suits, very daring at that time, with matching oilcloth swim caps like a waterproof baby's helmet tied under the chin. I still remember the school sports, poised on the diving board, hearing only the sounds of birds and the river. I executed a wonderful forward pike dive. I still remember the feeling of having done well, gaining points for my house, as I surfaced to the cheering and clapping from the girls on the terraces. I also achieved swimming distance certificates and a Life Saving Bronze Medallion.

182 Taylor (1994), p. 258. 
Our Art teacher was also our singing teacher. I recall learning 'Gaudeamus', 'Horo My Nut Brown Maiden', 'Angels That Around Us Hover', and the School Song. In Art and Craft in my third form year, I was encouraged to create a patchwork dressing gown. Many others contributed patches that were pressed, tacked, and then feather stitched in red embroidery cotton onto an unbleached calico backing. The back, fronts and long sleeves were then assembled into a fully lined seamless garment of school and community memories, trimmed with red corduroy velvet. An attractive, warm, practical gown, much admired, it served me well for many years and reminded me of high school.

\section{PUPIL RESISTANCE}

I recall a third form sewing class. I was so excited. Make a dress? This was something I could do. My only new summer dress. Our mother let me choose the pattern and buy the fabric at the local draper's. I arrived at school ready to start. I remember the frustration of waiting week after week for approval of pattern placement, cutting, pinning, tacking in preparation for sewing, and queuing for a sewing machine. I decided to finish my dress at home. I spent a whole weekend sewing. I took my finished dress to school. The teacher was furious. So was I. She accused me in front of the class of 'getting my mother to sew my dress'. I needed to know the seriousness of my transgression, so I was told to 'sit there and faggot my slip', a pink rose sprigged crepe-de-chine petticoat for her trousseau. I did not argue. I stared. The teacher did not want to know that she was reaping the benefit of our mother's excellent tuition. I sat with my back to the class. I stitched and securely faggotted the back to the front. I still remember my feeling of satisfaction with my first public, silent, but active demonstration against what I saw as a gross social injustice. I do not recall any follow-up. The incident was my public demonstration of Te Whiti O Rongomai's passive resistance. Outwardly I appeared to comply, but inwardly I resisted. ${ }^{183}$

\footnotetext{
183 Te Whiti O Rongomai was a deeply spiritual Chief at Parihaka in South Taranaki during the Taranaki land wars. He was a pacifist who wanted to settle land differences through negotiation. 'He would not cooperate with the government and permit the spread of colonisation in his District
} 
Upon reflection, I exhibited the same pattern of learning behaviour as in primary school. Learning continued to be relatively easy. Again, my level of performance was enough to hold a place in my class group. There was no pressure on me from anyone to increase my effort to pass examinations. I viewed high school as a means towards qualification for employment. In 1947, as a fifth former, I managed with little effort to pass the Government Shorthand Typist Examination, Junior; the Pitman's Shorthand Examination - 90 words per minute; and the School Certificate Examination in five subjects: compulsory English, Geography, Book-Keeping, Commercial Practice, Shorthand and Typing. Maraea Tippins comments that she:

went to primary school at Waitara and New Plymouth Girls' High School for three years. I took a commercial/business course. Then I had to leave school as my brother Charlie, who was running the farm, was in hospital and I had to stay home and milk and carry on the farm. ${ }^{184}$

At that time, such life experiences were not rare for girls who lived on farms.

POLIOMYelitis EPIDEmic ANd AfTERWARdS

In 1948 a poliomyelitis (infantile paralysis) epidemic swept the country. Schools were closed during February, and people were advised not to congregate anywhere. I decided I would enrol at the newly-opened Waitara District High School with my Waitara friends. It was not to be. The Deputy Principal talked to me about my examination passes and why I wanted to change to Waitara High School. Then he asked me to type a long letter. When I had finished, he looked at it and went away. Eventually he returned and said, 'Your level of work is higher than we would be able to offer you. I'm sorry but I cannot enrol you here. You should go back to New Plymouth Girls'.'185 I accepted his invitation to use the Waitara High School typewriters every day to practise typing until schools re-opened in March.

\footnotetext{
... He expected that Maori and European would live peacefully each on his own land.' Riseborough (1989), p.1.

184 Tippins, M. (1993), p. 281.

185 Meikeljohn, personal communication, 1948.
} 
Back at New Plymouth, I was democratically elected a prefect and my silver school hat badge was dipped in gold. My School Certificate was endorsed. I sat and passed the University Entrance Examination in three subjects, English, Geography and Botany. No one discussed the value of University Entrance, or the second year sixth form Higher Leaving Certificate, with me or my parents. Because of my primary school early promotion to Standard One, I was not yet old enough to go to Teachers' Training College.

I started 'playing' community hockey in the left wing position for a newly formed Waitara Women's team. I remember 'playing' for selection for the Taranaki team trials. Two of us 'played' equally well. The other girl was chosen. The selector, S. McRae, told me, 'You both 'played' well and we couldn't choose between you ... she was older and it was the last year she could 'play' representative hockey. You have plenty of time.' Immaturity had reared its head again. I knew I was the better player. I never 'played' another game of hockey there, even when asked. I also 'played' social Indoor Basketball. I became a St John Ambulance cadet in grey uniform, attending local Saturday sports fixtures, partnered with an experienced male. I remember assembling in the New Plymouth Army Hall for inspection by Lady Mountbatten, who was visiting New Zealand with Lord Louis Mountbatten. The local Waitara Women's Surf Lifesaving Club also attracted me. We had only a reel and belt for rescue purposes.

In 1949 I became restless. I had tried the monotony and boredom of office work during the school holidays. The Police were recruiting women, but I was not quite tall enough. Then I turned to the Army, and found that my examination qualifications would give me entry as a corporal. Nursing did not appeal to me either. I knew the Freezing Works Bag Room, where local women operated the machines for knitting bags used to cover frozen meat carcasses, was definitely out. I was dependent upon public transport. Every employment avenue seemed to be bound by conformity to rigid rules, uniforms, nurturance or domestication. I repeat, a professional career for me was not discussed. I was a mere Commercial girl being schooled for a job implying later domesticity. Emphasis was placed on 'job' and 'work'. Teachers, nurses and secretaries carried more status than domestics in the 
employment hierarchy of women. Waiora Port comments that girls 'were directed to courses, some of which may have led to work in an office, but only on the way to their fate as homemakers and caregivers'. ${ }^{186}$

In 1949 I went into a second-year sixth form class of ten girls, but I had exhausted what I saw as being usefully occupied at school. At sixteen years of age, I sought my independence, with access to my own earnings. So, with our parents' refrain about getting a good job ringing in my ears, armed with a range of certificates and using the same non-discussion model that had been applied to me, I quietly proceeded to launch myself on the job market. At the end of the first term of my second sixth form year, unknown to my parents, having secured a position as an operator on the Waitara Post and Telegraph Telephone Exchange, I voluntarily left school in May 1949 to join the paid labour force. My decision caused some interesting dialogic encounters with teachers. One teacher said, 'In future, choose your friends for what they can do for you.' I thought that was very strange advice at the time. It was an aspect of social relationships to which I was totally unused, and did not understand. The Acting Head Mistress farewelled me with, 'It's just as well you're leaving because you would never make a student anyway!' She seemed to see me as a problem. It was another unjust high school encounter that I chose to ignore. I simply walked out with my head held high, as before.

\section{BECOMING A TEACHER}

Some days later our mother was telephoned by my previous Commercial teacher, who said, 'We desperately need a relieving teacher. What is Kura doing? Has she started at the Telephone Exchange yet?' That was how my mother found out that I had left school. My transgression was ignored. Instead of joining the Telephone Exchange, I returned to New Plymouth Girls' High School for the remainder of the year as an untrained Provisional Relieving Grade 1 Commercial Teacher of Arithmetic, Typing and Shorthand. The salary was higher than that on offer at the Telephone Exchange. On arriving at the staffroom, I was looked up and down. The

186 Port, W. (1993). Assimilation: Mission Accomplished. Te Pua, 2 (1), 8-.9. 
staffroom hierarchy was well established. Everyone had their own particular chair in their own particular place at the central table. No one presumed to encroach on someone else's chair or place. I recall my first specific experience of being silently and deliberately put down and made to feel an inferior being in the presence of very superior beings. I was ignored by the Acting Head Mistress and most of those teaching the academic classes. I learnt that look and how to deal with it very quickly. I recognised the knowing of my place in the school. I really appreciated my previous Commercial and Physical Education teachers, who helped me settle into the staffroom. It was not until I became a certificated teacher myself that I realised that those two women had positioned me where I would not have to make eye contact with other more formidable staff in their academic gowns. The older Commercial Teacher patiently mentored and guided me daily in subject preparation, goals to be achieved, and the homework and marking of third and fourth form class work for which I was timetabled. My own class experience of shorthand dictation, using a stop watch, became very useful. Towards the end of my six months relief teaching, the school was inspected by the New Zealand Department of Education Secondary School Inspectorate. I was offered a position at Stratford Technical High School, to commence the following February. I viewed their comment as praise for my efforts, but to take that job, I would have needed transport or would have had to leave home. According to local oral testimony, Maori did not live in Stratford because one day Taranaki, our mountain, might return to the Central Plateau, and Stratford was in his path. I did not want to be caught by any travelling mountain. Having decided I would be a teacher and having applied for teacher training, I declined with, "No thank you. I want the piece of paper that says I am a teacher.'187

I was selected for interview, and presented myself at the New Plymouth Boys' High School interview room to face a panel of adults sitting behind a long table. The chair for the person being interviewed was placed in the middle, squarely in front of this intimidating line-up. I was aiming for either Commercial Teacher Training or the Primary Teacher Training Course. The only question I remember being asked was,

\footnotetext{
187 New Plymouth Girls' High School Register, 1941-1955, Entry no. 19, dated 6.2.45, shows my school leaving date as 27.5.49. Under Destination. 'Post Office' has been deleted and replaced with 'Training College'.
} 
'Did you make that suit you are wearing?' Very strange, I thought, in my smart dolman-sleeved beige corduroy velvet suit, partnered with a tie-necked red filmy cotton voile bishop-sleeved blouse, pure silk stockings, navy blue handbag and matching navy platform court shoes. I was comfortable in myself. Due to the baby boom after World War II, there was a desperate shortage of teachers. I recall stating that if I were to be accepted, I would not go to a residential college. Again, no mention of university. From the institutions I was offered, I chose Christchurch Teachers' Training College.

Reflecting upon my high school years, socialising with my peers was limited to sports, cadet activities, church functions and Saturday films. We did not have time to be adolescents because of our many home chores, and few other social community opportunities, apart from family birthday celebrations and church functions. I was also immersed in creating and sewing my own clothes on our mother's Singer treadle sewing machine. I do not remember any sex education at school, and it was certainly not spoken of at home. In many ways, we were totally naive. We socialised in groups, with very little boy/girl pairing off. Like my primary schooling, my secondary school years were generally happy ones, and I had expanded my life skills. Unfortunately, although our mother kept my school reports for many years they finally vanished, I suspect during the move to our bigger house when I was at Teachers' College. Again I recall one statement that was consistently repeated: 'Kura is an erratic worker who needs to try harder.' Neither I nor my parents knew what that was all about so nothing was done. As one of the Commercial Course girls, my marks were not of any great consequence. I was also told that I was incorrigible. Again, no discussion. High school helped me hone my Pakeha skills and behaviours, as well as firm up my decision to equip myself to be an independent Maori/Pakeha woman.

\section{Concluding Comments}

Our mother was my most powerful consistent influence. Whakapapa, my Maori/Pakeha family and my home circumstances were the keystones of my life. They provided fertile 'playgrounds' for dialogic encounters through social practices 
and relationships in schooling and other communities, strengthening and reshaping my identity as I matured from infancy through adolescence to the threshold of adulthood. Firm behavioural boundaries and the unquestionable everyday routines and expectations of our parents, my extended family and the schools I attended framed third spaces of negotiation. Cultural flexibility was a spontaneous Maori/Pakeha blend, or sometimes Maori inflexibility. The seeds of independence, resilience and endurance that had germinated through home, community and school continued to flourish throughout my years at New Plymouth Girls' High School.

During my schooling years, 'government policy remained fundamentally concerned with amalgamating Maori - socially, culturally and politically - into Pakeha society'. ${ }^{188}$ I had grown into a brown Pakeha for entry to the Pakeha workforce, able to operate confidently as Maori, Pakeha, or blended Maori/Pakeha. I was adamant that I would never ever live the same life as our mother. I was determined to be an independent Maori/Pakeha woman teacher, in control of my own circumstances. I knew I would face many social barriers. By the time I had completed provisional relief teaching, my vocational self was preparing for the world of teacher training and my future independence.

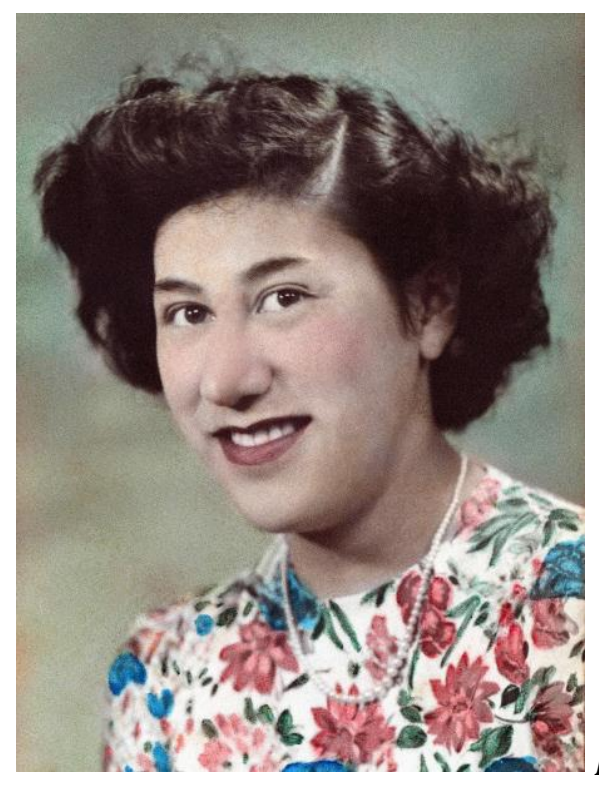

Figure 2. Kura Marie Teira Taylor, aged 16, 1948.

188 Anderson, A., et al. (2014). Tangata Whenua: An Illustrated History. Wellington: Bridget Williams Books, p.352. 


\section{CHAPTER FOUR}

TEACHER TRAINING, TEACHING YEARS AND REFLECTIONS

$$
1950-1990
$$

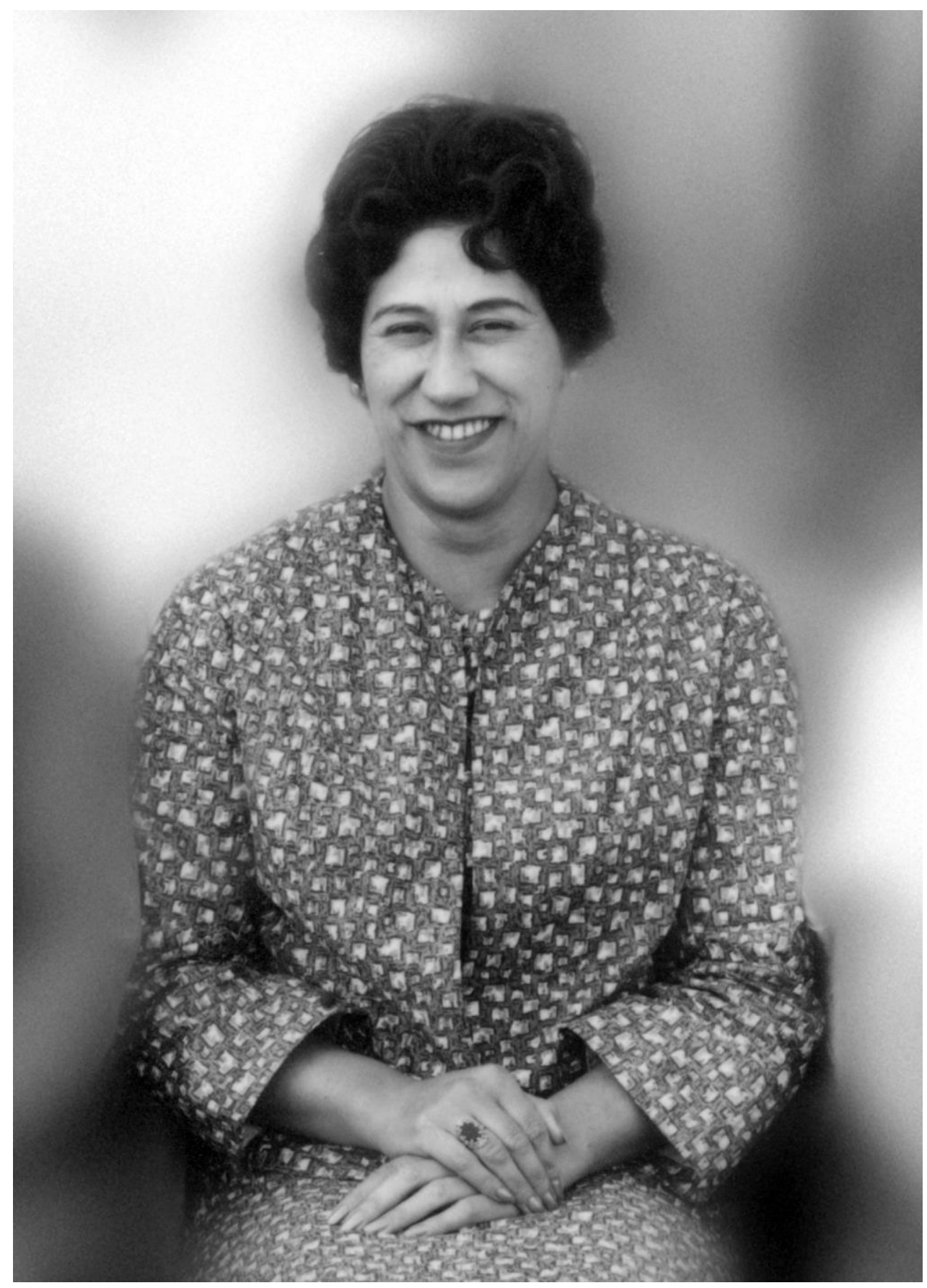

Figure 3. Kura Marie Teira Taylor, 1969, Teacher at Cornwall Park School, Greenlane, Auckland. 


\section{INTRODUCTION}

Chapter Four, 1950 to 1990, covers the two-year Division A Primary Teacher Training Course at Christchurch Teachers' Training College, and my employment years following qualification as a certificated teacher. Central to this section is my 'playing the games' of conformity, during full employment as a teacher, to rituals, criteria, statutory requirements and early promotion.

I became highly politicised in education and community organisations whilst retaining my identity as Maori/Pakeha. This chapter explores selected events in which the social processes of concientisation, politicisation, and ritualisation were woven into the fabric of my relationships during my training and employment years as a teacher. Conscientisation ${ }^{189}$ was embedded in my increasing awareness of the nature of teaching, teaching as a vocation, and being a Maori/Pakeha Woman Teacher. Politicisation was two-fold. The first aspect encapsulated the social environment of communities, the dominating Pakeha culture of school, classroom teaching, and the inflexible process of Pakeha assimilation and integration of Maori ${ }^{190}$. The second was in my community activities and the employment-related New Zealand Educational Institute, NZEI, the professional organisation of primary teachers, which consulted with government and negotiated for improvements in, for example, Maori education, conditions of service, appointment, promotion, and salary awards. The New Zealand Educational Institute and community organisations enabled politicisation, alongside retention of my identity as Maori/Pakeha. Ritualisation ${ }^{191}$ was the game 'playing' competitiveness in securing teacher appointments, improving qualifications, promotion, committee membership, teaching and teacher status.

Theme threads of Whakapapa, Family, Identity; Cultural Flexibility and Dialogic Encounters; Resilience and Endurance are interwoven throughout the wealth of activity in negotiation spaces that I was involved in during my years of full

\footnotetext{
${ }^{189}$ Smith, G. H. (1997)

${ }^{190}$ Smith, G. H. (1997)

191 Maclean, (1992)
} 
employment. Selected teacher training and teaching experiences along four strands of text focus are indicative of my survival decision-making within the education system. Inevitably, over forty years, there were major educational changes. Verbatim comments recalled from my years of employment are noted. The chronology at the beginning of this thesis lists my extensive wider employmentrelated and community involvement during these years.

The empirical evidence of this chapter will show firstly, the effect of training on the development of my Maori/Pakeha Woman Teacher identities, relationships and teaching appointments. Secondly, my involvement as Maori/Pakeha in three organisations during the years when I was employed in the New Zealand Primary Schools Education Service with specific participation in three Teacher groups and one community related group: the New Zealand Educational Institute, the New Zealand Teacher Registration Board, Maori Women in Management, and Te Ropu Wahine Maori Toko I Te Ora, the Maori Women's Welfare League.

\section{Aspects of Teacher Training And TEACHIng EXPERIEnces}

From choice, I spent forty years teaching primary school infant/junior classes. After two years of teacher training, one year as a Probationary Assistant and two years of relieving teaching, I held senior positions with responsibility for infant/junior classes for thirty-five years when wide ranging changes in education were initiated. My teaching experiences with large infant classes were orientated with the government's assimilation policies for Maori and the continuing espousal of educational deficit balanced with learning success and enjoyment. My involvement in committees and related activities resulted not from my planning, but from my being in a certain place at a certain time.

In reflecting upon my training and teaching years I found that I did not start out nor plan to do the things I have done. Of the three career choices available to me, nurse, teacher or secretary, I decided to be a teacher. My life has evolved around that 
personal commitment as an individual operating from my Maori/Pakeha woman collective perspective.

\section{Christchurch Teachers' Training College ( CTTC)}

The 1877 Education Act provided for a national system of schools to replace the provincial system. Christchurch Teachers' Training College opened in 1877, as the Training Department of the British patterned Christchurch 'normal school'. By 1888, the College had established itself' with fifteen teacher trainees. Of significance was acceptance by the Department of Education and the Education Board of the principle that all students should receive a training allowance, however meagre'.192 From its earliest years, recruitment and selection, curriculum, theory, qualifications, school experience and the finance to sustain teacher education posed problems. As John Fletcher explains in his history of the College:

There are three generally accepted components of teacher education: general education, to develop well-informed and cultured teachers-healthy minds in healthy bodies; professional education, to help student-teachers understand the young, master the principles of effective teaching and become familiar with the content they will be required to teach; and practise teaching putting principles into practice. ${ }^{193}$

Unfortunately the 1880s Depression brought high unemployment, poverty, distress and soup kitchens, and the 1888 earthquake damaged the normal school stonework, but by the 1890s the economy was improving, and in 1905 regulations were introduced for the examination and classification of teachers. ${ }^{194}$ In 1934, because of the dire state of the economy, a fall in student numbers and teachers' difficulty in obtaining employment, the College was closed, but it re-opened in 1935.195

With new technology, Christchurch became known as a city of bicycles, an efficient mode of transport. I remember cycling to the College and to schools for teaching

\footnotetext{
192 Fletcher, W. J. (2001). A Sense of Community: The Christchurch College of Education 1877-2000. Christchurch: Christchurch College of Education, p. 48.

193 Fletcher (2001), p.8.

194 Fletcher (2001), pp. 56, 67.

195 Fletcher (2001), p.153.
} 
experience sections, and seeing the warm colours that beds of spring tulips and daffodils brought to parks and gardens, contrasting with the bitter cold of winter winds sweeping off the snow-clad Southern Alps. I also recall the day, during my second year, when snow floated past the windows of the College like a myriad of soap flakes. Some of us had never seen snow falling.

When I reflect upon my selection for teacher training in 1950 and 1951, I realise that I had not then appreciated the importance to my parents of my leaving home. At seventeen, I was the first of our family to escape the limitations of Waitara. On my own, I was going to an unknown different Maori tribal area. After the death of our father in 1969, I learned of my whakapapa linkages to tracts of inherited Maori land in the South Island. Our mother, her sister (our aunt), and the eldest of my brothers took me to New Plymouth to embark on my totally new experience. I boarded the bus to Wellington, caught the overnight ferry to Lyttelton and experienced sea sickness. The next morning I was on the train to Christchurch. My bicycle followed. I knew there were few Maori in the South Island, and I was destined for another predominantly Pakeha learning institution where Maori were invisible.

I remember little of my early-morning arrival in Christchurch except reporting to Bishop Julius Hostel. 'A constant preoccupation of the College authorities was finding suitable board and lodging for out-of-town students',196 and this was closely monitored. Because of my Maori/Pakeha upbringing I had no problems sharing rooms in Pakeha private homes. During my second year I decided to find a bedsit. I rented what I could afford, overlooking the Avon River in a block of brick terrace houses, later demolished to make way for the Christchurch City Town Hall complex. I had a one-room bedsit with balcony, and shared the bathroom and the tiny kitchen, in a walk-in cupboard, with a Pakeha shop worker tenant. All was fine until the roof leaked, and I went back to college for help. I was told by the Dean of Women that 'Our students do not go out and find themselves flats to live in.' I was sent back to private board with a Pakeha widow. She had a daughter with a physical disability, which was described as 'spastic', but in all likelihood was cerebral palsy.

196 Fletcher (2001), p.189. 
Reflecting on my travel and accommodation, I realised that although I had done no prior travelling at all, my mother's expectations and grounding in independence and common sense were fundamental to my safety, exploration of new relationships and appreciation of new experiences, as my identities spontaneously re-shaped according to my social situations.

As a teacher trainee, I received training allowances that 'while by no means generous, were adequate for the lifestyles of the time'. 197 After I paid board I had five pounds left for books, stationery, other College expenses and leisure until my next allowance payment. Part-time, poorly paid, post-war employment for women was fairly readily available. Like many students, I packed chocolates at Aulsebrook \& Co.'s biscuit, cocoa and chocolate factory for three hours on three nights each week to supplement my allowance. Firmly grounded in the work ethic, I returned home for the long Christmas holidays and worked as a wardsmaid at New Plymouth Public Hospital. I saved and survived during training until I began my first salaried teaching appointment in 1952.

I was fortunate also to be financially supported by the Taranaki Maori Trust Board with a grant of $€ 80$ each year. I was also grateful to my parents for their input. I spent my grants on books, stationery, College field trips and other in-College expenses. I designed and made most of my clothes, from soft wool fabrics for the winter and cottons for the summer, during the long Christmas holidays. Through frugality underpinned by our mother's axiom, 'If you can't pay for it you don't have it,' I continued to survive with part-time and holiday employment.

I arrived at College as an eager young primary school teacher trainee poised to soak up new learning. I recognised the Principal, Duncan McKay, as the Agricultural Adviser who had visited Waitara District Primary School to speak to us about compost and vegetable gardens. Fletcher ${ }^{198}$ records Duncan McKay as a Scottish Highlander who immigrated to New Zealand in 1913. He began as an untrained teacher in 1916, and served in World War I on the Western Front from 1917-1918.

197 Fletcher (2001), p.192.

198 Fletcher (2001), pp. 171-172. 
Returning to New Zealand in 1919, he resumed teaching and in 1922 completed a 'pressure cooker'199 one-year course for older students at Dunedin Teachers' Training College. He completed his Bachelor of Arts degree extramurally in 1926 at Victoria University College, Wellington, and in 1929 was awarded his Master of Arts degree at Christchurch University College. From 1928-1930 he was principal at Ohura District High School in Taranaki, and in 1939 was appointed Taranaki Education Board's senior instructor in agriculture. In 1943 he became the eighth Principal of Christchurch Teachers' Training College. Fletcher writes:

He was a man who made a habit of thinking before speaking ... and then speaking good practical common sense ... He communicated a strong sense of the importance of the teacher's task and the need for teacher-trainees and teachers to display a high level of conduct and commitment. His educational philosophy ... was very much a liberal one. He was concerned that his students received not only a good grounding in the art and science of teaching, but also that they became well-rounded people with a range of academic, sporting and cultural interests. A concern he expressed several times in annual reports was the inadequacy of the then two-year teaching-training course. He was a strong advocate of a three-year one ... Harmonious staff relations ... were a feature of his time as principal. In his way he was a passionate believer in fashioning democratic and civilising values. ${ }^{200}$

Reflection enabled me to recognise that Duncan McKay and Christchurch Teachers' College were profound influences upon two years of my life, adding to my confidence, Maori/Pakeha relationships and survival knowledge.

\section{NEW DiRECTIONS IN EDUCATION}

A soaring birthrate was characteristic of the post-war years from 1945 on, and Clarence Beeby was pushing ahead with changes to the education system. According to Fletcher:

He broadened the primary school curriculum through new programmes in art and physical education, and built up teams of advisers to support them. He introduced a new series of infant

\footnotetext{
${ }^{199}$ Fletcher (2001, p.177), notes that the 'pressure cooker' course of 32 men and 18 women begun in August 1949 was the Department of Education's emergency teacher training course for older students to meet the 1940s teacher shortage. Competence and life experience were accepted in lieu of academic qualifications.

200 Fletcher (2001), pp. 181-183.
} 
readers ('Janet and John'), the use of which involved more modern methods of teaching reading. He introduced 'age promotion' to replace the old and outmoded 'standard pass' system. He unified (in 1945) the two kinds of secondary schools (technical high schools and secondary schools) under the new title 'post primary schools'. He encouraged a freer atmosphere in schools, through activity methods and centres of interest, by relating the world of the school to the world outside, and so on. ${ }^{201}$

As with all changes, there were the progressive supporters, and also the conservative detractors, who used the derogatory colloquialism 'playway' to describe their views of these changes, and discredit Beeby. Clarence Beeby himself did not use the label and 'was greatly in favour of good solid learning, but he wanted it made as enjoyable as possible'.202 In 1950, when I began my training, a National Government was in power, and R. M. Algie became Minister of Education. He kept an 'open door' policy of consultation with the New Zealand Educational Institute (NZEI) Dominion Executive about, for example, changes in curriculum and conditions of service. I became a junior member of NZEI. ${ }^{203}$ At that time women were eligible for retirement on reduced superannuation after thirty years of service, ten years earlier than men. My two years at Training College would be included in my years of teaching service for calculation of superannuation when I retired.

\section{'Division A' Primary TEACHER TRAining}

The Division A Primary Teacher Training Programme, providing two years of general training across all levels of the primary and intermediate curriculum, with access to university, was then the norm. One year as a supervised Probationary Assistant, i.e. teaching in a primary or intermediate school 'during the first year after a two-year teacher college course', ${ }^{204}$ followed for teacher certification. A third year of specialist training for the teacher advisory service was offered to selected students.

\footnotetext{
201 Fletcher (2001), p.167.

202 Ibid.

203 Simmonds, E. J. (1983). NZEI 100: An Account of The New Zealand Educational Institute 1883-

1893. Wellington: NZEI, p. 167.

204 Simmonds (1983), p. 172.
} 
The first year of 'mixed-sex groups', predominantly women, was 1950.205 Six weeks in college was followed by six weeks on section in schools for teaching practice. At college and in the schools, we were introduced to the new Janet and John reading series for teaching infant classes.

Before going out on section, we were all instructed on the proper dress standard. Skirts and stockings for women were a requirement. Trousers for women were definitely out. A critique lesson for written comment and discussion by a visiting College Lecturer was required. At the end of the teaching section we were marked on, for example, lesson preparation, teaching performance, appearance, dress and punctuality. We returned to College on Wednesday afternoons for discussions with our tutor lecturers, assembly and sports. I 'played' indoor basketball for the College team, hockey socially, and learned to fence. Swimming was compulsory for a pass in Physical Education and certification.

'In 1945 a Maori Club was formed'206 and Maori first became visible. The Club met in out-of-lecture time. During 1950 and 1951 the Club was led by the Maori women students educated at Te Waipounamu, the Christchurch Anglican Secondary Boarding School for Maori Girls. Women were barred from marriage during teacher training. I recall six Maori women in the 1950 intake, but no Maori men. Of three Maori women in the 1949 intake, one dared to challenge authority and married in the August holidays of her second year. She disappeared.

During our second year we were able to choose the topic for our final Social Studies assignment. My project was about Owae Marae at Manukorihi Pa in Waitara, and my Maori/Pakeha identity. At Waitara I interviewed one of the old people at the marae and had a tour of the carved house, conducted by a local male elder. I was given a copy of the 1936 ceremonial booklet, did my research, and finally produced what I thought was a very commendable project. To my horror I was summoned to hear a plummy English voice inviting me to 'explain how useful said project would be'.

205 Fletcher (2001), p.188.

206 Fletcher (2001), p. 180. 
Reflecting upon those words, rightly or wrongly the message I received was that things Maori were not in vogue for the important task of teaching Social Studies. The silence of resistance and cultural flexibility again allowed me a dignified exit.

\section{Friday Night Club Alternatives}

We few Maori did not feel in any way different from the other students. However, we did have a different appreciation of dance and enjoyment at the Friday Night Club, when we had fun with rhythm and jive. On Monday morning four of us were summoned by the Dean of Women, lined up, and lectured on our impropriety: 'jitterbugging and jiving are not the kind of dances for Friday Night Social here at College. I am sure that if you go half-way towards the other girls they will come halfway towards you.' We were puzzled, but got the message that our dancing was not acceptable. 'Outside the College there were regular Saturday night dances about the city and some College students at least were keen attendees'.207 We found alternatives at the public Caledonian Hall, and the Union Rowing Club at Brighton, where Tommy Kahi's band with electric guitars, saxophones and drums 'played' Maori and Pacific Island music. Both venues were viewed as unworthy for students hoping to enter the ranks of teachers. We also joined a community Maori culture group. We performed at local Sunday evening concerts, and met Maia Aston, a stunning, elegant, Maori woman ex-WAAF, Maori Affairs Officers Mori Ellison and Kitchener Hopa, the Witten-Hannahs, a Pakeha family, and Noel McKay, a very talented female impersonator, who designed, created and sewed his own costumes and shoes for his song and dance routines. We all became very good friends.

In 1951 the College participated in the Canterbury Centennial celebrations. As a community, we vigorously performed Maori action songs and poi dances. As trainee teachers, we decorously danced the Maypole in Hagley Park.

207 Fletcher (2001), p.189. 
Reflecting on our relaxation and recreational pursuits, I was aware that we few Maori operated somewhat differently from the wider Pakeha student body. We were successful in culturally flexible Maori and Pakeha dialogic encounters with the wider community, and were not recreationally dependent upon College student relationships. Strengthened by our whakapapa, we spontaneously moved between Maori and Pakeha cultures, confined only by our family upbringing of what was acceptable behaviour. We had such fun!

\section{HITCH-HIKING}

In 1951 the National Government, with Sydney Holland as Prime Minister, used the armed services to break the waterside lock-out, which had paralysed the ports of New Zealand for six months. ${ }^{208}$ The army worked on the wharves, and the navy in the coal mines. A Waitara friend and I decided we would hitch-hike to Porter's Pass. Two young naval men came up from the mines to go deer stalking. We all plodded through the patchy snow. We saw one dead deer. Cold and shivering, we arrived back at the hotel to a massive stone fireplace with a huge tree trunk lying across the fire grate, flaming, crackling and sparking. After it was almost burned through, the hotel proprietor rushed outside, started the tractor and pushed the trunk further into the fire. It was a very different experience in open fires for us. Once we hitched from Timaru with a driver who was delivering a brand new car to Christchurch. We found ourselves in a rapidly rising stream, water pouring into the car. We felt really sorry for the driver. Luckily a local farmer on his tractor rescued us and we were able to continue on to Christchurch. The third time we hitched uneventfully from Wellington to New Plymouth. We met some really interesting elderly characters who initiated conversations about where we were from, suggested other places to visit, and invariably wanted to know if we wore two pairs of socks in our boots. My reflections reminded me that we felt really safe hitch-hiking. We behaved sensibly and were appreciative of those who gave us lifts, passed on local information and treated us well. We saw much of the country, had opportunities to interact with a wider group of people, and broadened our social behaviours.

208 Roth, B. and Hammond, J. (1981). Toil And Trouble: The Struggle for a Better Life In New Zealand. Auckland: Methuen Publications (New Zealand) Ltd, pp. 145-155. 
In December 1951 I graduated from Christchurch Teachers' Training College ready to begin my Probationary Assistant year, from choice, in the Native/Maori Primary Schools Service.

Established in 1867, Native Schools were essential to the assimilative process. The Native School system ran parallel to the public primary school system until 1969; Māori pupils could attend either. However, once Māori pupils reached Standard 6, no statefunded Māori secondary schooling was available until the establishment of Māori district high schools in 1941. Māori wanting to extend their studies were to attend a state high school, where Māori pupils were rare, or gain entry to a Māori denominational boarding school via a Department of Education scholarship. ${ }^{209}$

On reflection I realised that I was probably one of those rare Maori pupils educated at a state high school, New Plymouth Girls' High School.

\section{TEACHING EXPERIENCES}

New Zealand's national system of education, covering the curriculum, examinations and standards, made moving between schools relatively simple. Maori schools were administered by the New Zealand Department of Education. A promotional requirement for salary increases was that two years be served in designated country service rural schools, or else a salary bar would come into operation after a specified number of years. Like many others, I chose to complete my country service as soon as possible. Maori Schools were usually country service schools. I was appointed as a Probationary Assistant for one year, prior to teacher certification, to Ruatoki Maori District High School, in the tribal territory of the Tuhoe Iwi and Prophet Rua Te Kenana in the Bay of Plenty.

Most students decided to return to their home districts, but I was on the buses again to a place I had never heard of before. Our mother was not happy. She did not

209 Taylor and Matthews (2016), p. 231. 
explain why. Her body language said it all. She had heard stories about Ruatoki and Tuhoe people from her brother, who farmed near the area, and drawn her own conclusions. My salary was $£ 299$ plus $£ 46$ in allowances in 1953, my first year of certificated teaching. This increased to $£ 467 / 10 /$ - plus allowances of $€ 75 / 18 /$ - in 1954.210

\section{RUATOKI MAORI LAND DEVELOPMENT}

In the 1930s, Apirana Ngata became the first Minister of Native Affairs to be appointed from a Maori electorate, and ranked third in the Cabinet. His portfolio included planning schemes for the development of under-utilised Maori land. Ranginui Walker notes that he was:

... a man of such extraordinary gifts of intelligence, energy and foresight that among his own Ngati Porou tribe, he was esteemed as a god among men. Even as an adolescent he had a prescient view of his mission in life to emancipate his people and uplift them to achieve the equality with Pakeha that was inherent in the guarantee of British citizenship under the Treaty of Waitangi. In a lifelong struggle for equality Ngata had a huge impact on the social, cultural, economic and political landscape of the nation. His place in history is that of a mediator for a modus vivendi between two cultures of disparate traditions, one the explorer, the other the victim. ${ }^{211}$

The Ruatoki Block was a land development scheme where the consolidation of scattered land interests was facilitated by local leaders. Ranginui Walker also notes:

Under the Native Land Claims Adjustment Act, the Minister of Native affairs was authorised to advance money 'for the better settlement and more effective utilisation of Native land...and the encouragement of Natives in the promotion of agricultural pursuits and of efforts of industry and self-help'.212

Although the Tuhoe people were engaged in growing maize and supplying milk to the local cheese factory, there was still a need to improve herds, realign fences and drains, and improve buildings and equipment. Low-cost houses were built with

\footnotetext{
210 New Zealand Department of Education (1952-1954). Personal file, Service Schedule, Maori School Teacher.

211 Walker, R. (2001), He Tupua: The Life and Times of Sir Apirana Ngata. Auckland: Viking, p. 11.

212 Walker (2001), pp. 234-5.
} 
indoor cooking facilities and plumbing. Land adjacent to the school was set aside for a Marae and Carved House. Because of population congestion, it was envisaged that another 2000 acres of Tuhoe Maori land would be needed for expansion. ${ }^{213}$

The Maori-speaking Junior Assistant ${ }^{214}$ and I were fortunate to be boarded with a family next to the school and opposite a Marae. According to Clarence Beeby:

Native School Teachers had always been a special breed. Man and wife were usually headmaster and infant mistress. They were teachers and advisers to parents on health, sanitation, law and the understanding of the rights of citizens in the wider New Zealand community. Native schools were better staffed, and Native schools had better facilities for care and nutrition than Education Board Schools. Some of the best teachers in the country were attracted to Native Schools while weaker teachers were discouraged. Even though schooling was in English, officially there was no longer any limitation on the use of the Maori language by children. ${ }^{215}$

\section{Arrival at Ruatoki}

I travelled by New Zealand Railways Road Services Bus and went to the home of the Headmaster, Mr Holyoake, and his wife, the Infant Mistress, by local taxi. Kuni Jenkins and Kay Morris Matthews note that 'the rural village Native Schools had Pakeha teachers bring civilisation by living alongside Maori in the district'. ${ }^{216}$ I was instructed to, 'Get on the bus tomorrow and go into Taneatua to Fred Fitchett, the Saddler. Tell him who you are, where you are and ask him to select a good piece of leather and cut you a strap. He will know what to do. This is the regulation size and weight.' At nineteen, reporting for my first teaching position, I did as I was told. Then

\footnotetext{
213 Walker (2001), p.248.

214 Simon, Judith, Editor, 1998, p 61 The Department, at an early stage, adopted a policy of appointing uncertificated 'junior assistants' - mostly young Māori women to the Native Schools largely to provide a bridge between the community and the school. This was particularly important when the majority of new entrants spoke only Māori. In this way the Native Schools provided one of the few vocational opportunities available to Māori women, until the middle of this century, that was not linked to domestic service. From the late 1930s onwards junior assistants were encouraged to study by correspondence under the guidance of their head teachers to qualify for entry to training college. See also Barrington and Beaglehole, 1974, p 152.

215 Beeby (1992), pp. 206-207.

216 Jenkins, K. and Morris Matthews, K. (1995). Hukarere and the Politics of Maori Girls' Schooling. Palmerston North: Dunmore Press, p. 16.
} 
I was taught how to use the strap, why and when to use it, and to record the event. I still have that strap, reminding me of those authoritarian days.

\section{MY FIRST CLASS}

My open-air classroom was of the type described by Helen May: it 'had large glass folding doors designed to catch the maximum of sunlight and fresh air and the pupils had access to grassed play areas'. ${ }^{217}$ It opened on to a wide verandah. My class was sixteen six- and seven-year-old fluent Maori speaking (Tuhoe dialect) children, whose English language reached an equally high standard. I was mono-lingual, speaking only English. The children had been at school for up to two years. Many were named after places where relatives had fought during World War II. I had a planning session every Thursday after school at the Headmaster's house, where I was told to first 'make the tea Kura'. Then we developed the next weekly plan, built upon my recorded observations of the children's learning progress in relation to the New Zealand Primary School Syllabus, the annual Ruatoki Maori School Scheme of Work, and an estimation of where the children's learning should be by the end of each term. Classroom teaching was planned in the form of 'activity methods and centres of interest'. ${ }^{218}$ A daily timetable template was drawn up across a double page of my Teacher's Work Book, supplied by, and the property of, the New Zealand Department of Education. A flap was attached to the left side in timetable order. The double page was then ruled into six columns, one for each day, Monday to Friday, with one column on the right to note the progress (or not) of individual children as we worked. It was a simple, clear, easy process to follow as I taught. More importantly, I soon became adept at recording and planning from my observation notes. This model stood me in good stead for the whole of my career.

On reflection, young teachers on my various staffs over the years also found this process useful to plan for children's learning needs and successes. Required planning sessions further conscientised me in my teacher role, as I drew on my training to apply theory to practice with my own class.

\footnotetext{
217 May (2011), p.91.

218 Fletcher (2001), p. 167.
} 
Teachers at Ruatoki were dedicated, resilient and enterprising. Much was chalk and talk. The New Zealand Department of Education provided chalk. We made most of our own teaching resources, because of the paucity of commercially accessable teaching resources and the expense of what was available. After school and in the weekends we laboriously printed words with paint brush and yellow paint, and glued pictures on hardboard off-cuts from local sources. Over the weekend we used the bandsaw in the school woodwork room, sanded smooth the edges of every piece by hand, sized and then applied three coats of varnish on jig-saw puzzles, word matching, number games, and flash cards. For storage, we used tobacco tins and boxes which we scrounged from shops in Taneatua and Whakatane. The children really enjoyed the equipment we made, and used it carefully. Together, we created many guessing, matching and flash card games that could be played individually, in pairs, or in groups. I took much of what I made with me, and finally gave it all to a grateful friend in a South Auckland school.

We taught reading from the familiar animal-based Beacon Readers and the new, culturally unfamiliar, assimilatory Janet and John series. We used the children's familiarity with oral communication and phonics for decoding unknown English words, reading on, and then going back to read the whole sentence to establish the sense of what they read. Sometimes we re-wrote Janet and John books, substituting more familiar child experiences, with Maori names and concepts. We also wrote our own supplementary reading on blackboards and brown paper charts, incorporating the children's experiences, to build up personal libraries. These were shared amongst the children according to agreed criteria at the end of the year. We harnessed the children's energy and natural rhythm through curriculum learning games that allowed for knowledge, movement, understanding of and facility with English. We also roamed the large playground teaching English using the direct method. ${ }^{219}$ The Teachers' Monthly Guide and NZEI publications on the Teaching of Reading and Mathematics were also very helpful resources.

${ }^{219}$ Simon (1998), p. 151. 
On reflection, I recall how busy we were and how physically drained we became by the end of each day. Our rewards were the fun we had and appreciating the consistent progress the children made.

\section{Health and SpeEch Training}

Apirana Ngata's drive for Maori equality with Pakeha also included attention to sanitation, housing and improvement of living conditions. In August 1900 Maui Pomare, the first Maori MD graduate, returned from the American Medical Missionary College and was appointed Maori Health Officer under the Maori Councils Act. Pomare travelled the country visiting villages, investigating Maori health, examining water supplies, and advising on improving sanitation and hygiene. ${ }^{220}$ Both Ngata and Pomare attended Te Aute College for Maori Boys and were influenced by the Headmaster, John Thornton. Apirana Ngata was the driving force of the Te Aute College Students Association, involving mentors and links into Maori communities. ${ }^{221}$

I was instructed by Mrs Holyoake, the Infant Mistress, to 'Look in their heads and I'll look at their bodies'. My preparation for the health problems I encountered was abysmal. However, with the help of the District Health Nurse each Monday afternoon, we managed. Every morning we inspected teeth, fingernails and handkerchiefs. We taught speech training, practising daily where to place the tongue, how to shape the mouth and how to use speech organs to make the sounds of the English language that were different from the sounds of the Maori language. My Saturday elocution lessons during my own schooling were a valuable resource here. A Dental Clinic was also on site, with a part-time Dental Nurse who regularly checked the children's dental health.

\section{SChOol Cleaning}

Not only did the children respond well to learning, but in Maori schools under teacher supervision, they also 'had to do the cleaning and gardening on Friday

\footnotetext{
220 Walker (2001), p. 96.

221 Walker (2001), p. 74.
} 
afternoon'.222 They climbed walls to do high dusting, cleaned windows, polished floors, scrubbed, swept, tidied and cleaned out cupboards. In return the 'Department of Education supplied them with all their stationery requirements'. ${ }^{223}$ Standard roses lined the driveway into the school and the circular turn-around for the school bus. I recall that many visitors came to see the roses in bloom. My reflections on Ruatoki were also of tasting the rare delicacies of trout straight from the river, pan-fried on an open fire, and native pigeon preserved in its own fat. For the first time I rode a horse and a motor bike. I enjoyed Ruatoki and respected the people I came to know. Throughout my career I never ever taught in other schools as clean and sweet smelling as Ruatoki District High School and other Maori School appointments.

\section{BECOME SERIOUSLY ILL}

In December 1952 I was admitted to Whakatane Hospital and diagnosed as having toxic dermatitis. ${ }^{224}$ I recall that my illness started as a rash. The two Misses Bargrove, who were Anglican Missionaries recently returned from China, lived in the Mission House near Ruatoki School and thought I might have measles. Within a matter of hours I was very, very sick. The Holyoakes rushed me to Whakatane Hospital. After two months I was well enough to travel. I was discharged and went back to Waitara to convalesce. I returned to Ruatoki School for Term Two 1953 as a relieving teacher, and lived in the Assistant Teachers' flat in the old converted Headmaster's house with two other teachers and a Dental Nurse, at a rental of 10/per week deducted from my salary. ${ }^{225}$

Over the years I have often reflected with real gratitude upon my recovery, due to the Holyoakes' prompt action getting me to hospital for the excellent treatment,

\footnotetext{
222 Simon (1998), p. 53.

223 Simon (1998), p. 52.

224 'Toxic dermatitis is known medically as exfoliative dermatitis where the superficial layers of skin become inflamed and peel off. It is commonly caused by an allergy and can sometimes be fatal.' (Connor (1992), p. 33.)

225 New Zealand Department of Education (1952-1954).
} 
medical care and extensive sick leave entitlement I received under the primary school teachers' conditions of service negotiated by the NZEI.

\section{TEACHER GRADUATION}

After I graduated from Teachers' College and completed my Probationary Assistant year, my Trained Teacher Class C Certificate, dated 1 February 1953, arrived by post. Mr Holyoake told me, 'You've got twenty-four grading marks. Only one other teacher in New Zealand was better than you. She had a degree and they gave her one more mark. Now I'll tell you how I knew you would be a very good teacher when you came to us. Look at this.' My Teachers' College assessment was, Distinction. Beeby comments that, 'the senior inspector Ball gave higher gradings to outstanding teachers than occurred in other schools'. ${ }^{226}$

Reflecting upon my College and Probationary Assistant years, teaching at that time, unlike today, was like pioneering, demanding a high level of physical and mental stamina. We relied on teacher chalk, talk and creativity. We were dependent upon public transport, and our own ability to create teaching resources and build relationships as teachers with the communities in which we taught. I was very fortunate. Not only did I have very good teacher mentors, but I had regained my usual very good health and had the stamina to work extremely hard. My Trained Teacher Certificate and grading marks evidenced my capability as a teacher, a person and a Maori/Pakeha woman.

\section{RELIEVING IN RURAL MAORI SCHOOLS}

At the beginning of my certificated teaching career, I had to decide what next. Relieving teachers for Maori schools were in short supply, so from June 1953 to 1955 I took advantage of the situation. I moved every term, seeing as much of the country as I could, and delivering a curriculum aimed at 'cultural adaptation'.227 Under that concept, the Department of Education introduced elements of Maori Music, Arts and Crafts into the Maori Schools curriculum. Travel expenses for bus,

\footnotetext{
226 Beeby (1992), p. 207.
}

227 Simon (1998), p. 117. 
train and taxi were paid to each school by the New Zealand Department of Education Accommodation was usually found in the school district. All except Pukekohe Maori School were classified as country service for salary purposes. My teaching field was five- to seven-year-old children. Because of their rural to remote location, Maori Schools teachers were entitled to a shopping day each term. This did not always eventuate.

TE TII MAORI SCHOOL

Te Tii Maori School, in the Bay of Islands, was sometimes accessible only by the cream lorry. Heavy or continuous rain caused the unsealed road to turn to mud. After a long train, bus and local car journey, I was duly deposited on the Headmaster's doorstep and given a bed for the night. The next morning I went by launch to my boarding place.

I lived with a couple who ran the launch to Russell, did the school trip around the bay, and took parties out deep sea fishing. They told me, 'If you hear strange noises, the penguins come up under the house. They cry like babies.' During the oyster picking season, families lived under canvas and the children were collected from camp sites. I was not allowed a shopping day in Russell. Our leisure was basic to survival, involving teaching preparation, shooting at a kerosene tin with a .22 rifle on the lonely beach across the bay accessed by rowing a dinghy, eating oysters off the rocks, or gathering driftwood from the beach to fire up the stove and the copper for baths.

The woman I boarded, Mrs Hansen, with was a retired teacher. Prior to her marriage, on three days a week she had taught at the nearest local school. Then she rowed across the bay, caught her horse in a paddock, and rode to the next school, where she stayed for another three days. There her horse was kept in a stall by her bedroom. Then she reversed the process.

She was also a model of domesticity. She used flat irons like our mother's. Her cooking on a wood-fired range was also similar in flavour to our mother's. Her 
pantry was full of symmetrical bottled fruit and preserves, all made from produce out of her own garden and orchard. A small generator was used to provide electricity, and they had a radio to contact boats. The three daughters were away working or at boarding school. I had met one of them at Teachers' Training College in Christchurch; she was completing a third year of training for the School Advisory Services. Some years later, Te Tii School was rebuilt away from the foreshore, and an imposing marae now stands on the old school site.

WAIOMIO MAORI SCHOOL

Waiomio Maori School was also in the Bay of Islands. I lived with a family in Kawakawa, with whom I learnt to play canasta. The railway line went down the middle of the main street. My trusty bicycle duly arrived via New Zealand Railways, and I pedalled three miles from Kawakawa along the state highway and then down a metal road to the school. An orange orchard had been planted behind the school. The ripe fruit was picked by the children and shared amongst families.

\section{RAKAUMANGA MAORI SCHOOL}

At Rakaumanga Maori School, near Hamilton, I lived in a converted 'model cottage' in the school grounds. Judith Simon notes that:

From the mid-1930s model cottages were built in the grounds of a number of Native Schools to enable the domestic curriculum to be taught in a 'real life' environment. In the model cottages girls participated in day-to-day household chores, taking turns in cleaning, cooking and maintaining the general upkeep of the cottage. Often teachers and other pupils would be served meals during the school day.'228

\section{A Permanent Teaching Appointment}

After two years of relief teaching, I applied for a permanent teaching position. I was appointed by the Taranaki Education Board to Tikorangi School, in a wealthy

228 Simon (1998), p. 117. 
farming district near Waitara. I soon found that coming home to Waitara was not a wise choice. Distracting leisure pursuits with my childhood friends did not fit with my teacher persona. After one term I resigned, packed up and went to Auckland to meet friends from my Christchurch days. I soon found a job packing chocolates at Heard's, later the Nestlé factory, in Parnell and accommodation within walking distance.

Reflecting upon the free and easy life on the Auckland scene, I decided that dancing, dining and sipping with not a care in the world were not good lasting bedfellows with me either. One day by chance, in Parnell's shopping street, I met the Pukekohe Maori School Headmaster and his wife, with whom I had taught. They expressed absolute horror with what I was doing, and immediately made contact with the Department of Education. The Officer for Maori Schools offered me relieving work at Mohaka Maori School in Hawke's Bay, and anywhere else I wanted for as long as I wanted. ${ }^{229}$ The Department of Education negotiated release from my Taranaki Education Board permanent two-year teaching contract. It did not occur to me that I was receiving preferential treatment. I had not completed the minimum permanent appointment time at Tikorangi School to qualify for application for appointment to another permanent position.

My reflections upon my doubtful choices during that time showed that an influencing factor in my decisions was most probably immaturity, dating back to early primary school promotion.

MOHAKA MAORI SCHOOL

I was appointed relieving teacher at Mohaka Maori School in Hawke's Bay. I lived on a sheep station, bounded on one side by the beach and on another by the Mohaka River. The landscape showed many signs of the disastrous 1931 Napier earthquake. Three generations of one family lived in the sheep farm homestead where I boarded, near the mouth of the Mohaka River. I plodded a slow two-mile walk to school with

${ }^{229}$ New Zealand Department of Education (1952-54), Personal File, Maori Schools Officer correspondence, 2 July 1954. 
a five-year-old, along a loose metal road, over a swing bridge and up a steep hill to glorious ocean and land views from the top. Sometimes we went down to the swing bridge on the tractor. An older Maori woman who lived next to the school invited me to her home after school to make flax kete, baskets. Unfortunately I was not able to take up her invitation.

One stormy night we were at a school social evening when the swing bridge was blown off its supports. ${ }^{230}$ We were on the wrong side of the river. That necessitated a long involved trip to get back home via the old Napier Coach Road, by taxi, tractor and on foot. Rabbits had been a real nuisance and rabbit gates were still in operation on some farms, so we had to open and close the gates on the way as well. What an adventure in the wind and rain.

Gazing upon the living reminder of an aspidistra from Mohaka, snuggled under a king fern flourishing in my patio garden, I often reflect upon those days. The original plant was a wedding present to Granny McIver, grandmother of the family with whom I lived. I was told that as a bride, she carried the plant from Auckland to Mohaka by boat as part of her hand luggage. Having survived the earthquake, the aspidistra reposed in the hall by my bedroom doorway. I brought a root from it back to Auckland. Now, as then, it thrives on neglect.

PUKEKOHE MAORI SCHOOL

A long distance passenger train and a 6 am taxi deposited me at Pukekohe Maori School, south of Auckland city, in a huge market gardening area. Acres and acres of land produced enormous crops of potatoes, onions and other vegetables for the domestic market. Being Maori caused difficulty with accommodation. Eventually private board was offered with Pakeha women. The property owner was a mother with one daughter. She boarded a teacher, a bank clerk, and me - a house of

\footnotetext{
230 New Zealand Department of Education (1952-54), Personal File, Headmaster Mohaka School, storm damage leave, correspondence, 26 July 1954.
} 
females. As I recall, Pukekohe was divided into two factions: Pakeha haves, and Maori and other ethnic minority have-nots.

My reflections of Pukekohe are biased by the openly practised racism I observed. Kay Douglas and Kim McGregor explain racism as, 'occurring when one person attributes negative characteristics to another and treats them as inferior on this basis'.231 Maori were not permitted upstairs at the local picture theatre, nor would hairdressers cut, shampoo or set a Maori person's hair. One young Maori woman teacher, also at Pukekohe Maori School, was subjected to local business and community racist attitudes and the racist version of the Maori stereotype that thrived in Pukekohe. I did not put myself in those situations. Instead, every weekend I went to visit friends in Auckland.

\section{Permanent SEnior Appointments to Education BoARd Schools}

From 1955 to 1991, I was appointed to senior positions in large primary schools. My position was second in status and salary to the Headmaster/Principal, under the various titles of: Infant Mistress; Senior Teacher Junior classes (ST(JC); Supervisor of Junior Classes (SJC); and Assistant Principal (Junior Classes) (APJC). Titles differed according to state policy changes. The schools were predominantly white middle-class, very similar in composition and socio-economic status. Dawson Primary School, with its widely different cultures and working class families, was the exception.

I had never wanted to be a Headmaster, Principal or Administrator. I had always wanted to teach. I chose to remain in senior positions in the classroom with a class and teaching component. Organisation allowed for either one or two terms free of the responsibility of single class contact in a single classroom environment. My teaching strength was reading and writing. Because classes were large, I taught small groups or individual children with learning frustrations to a level where they

231 Douglas, K. and McGregor, K. (2000). Power Games. Auckland: Penguin Books NZ, p.73. 
could be merged easily into classes of their own age groups and hold that position. Young and inexperienced teachers seemed to be comfortable with the organisation, and could then cope with their large classes without the disruption of children with learning differences. The children seemed to enjoy success at their age levels. The arrangement also allowed teachers to have a sense of security, to plan for a full year, to establish class rapport, and to develop successful learning, reporting, and reward systems. Parents appeared comfortable, knowing their children were in a stable learning relationship with their teacher for a set time. I merged senior responsibilities with full-time class teaching during the year, as class roll numbers increased. Most of my teachers were women. I only once had a very good young male teacher on my Infant Staff. Many male teachers were ex-servicemen. The armed services influence was particularly noticeable in expectations of ability in Physical Education, and when marching with parade-ground precision from assemblies to the classrooms.

\section{Ruawai District High School, Northland}

In 1955 I was headhunted by Oscar and Thelma Holyoake for promotion as Infant Mistress to rural Ruawai District High School (DHS), in the Auckland Education Board district. ${ }^{232}$ Seven small schools, with rolls of fourteen to 53 children, had been consolidated and opened in 1929 as Ruawai District High School.233 I was directed to read, sign and lodge the application form, already filled in, that had been posted to me for appointment as a Scale 3C Infant Mistress. I waited for the appeals of much older and more experienced teachers to be heard. Then I was sent a second application, and was appointed to the second of the three most senior positions in the school. I had delegated responsibility for five classes: New Entrants (which I taught), and Primers One to Four, as well as a Probationary Assistant. My annual salary was the princely sum of $£ 999$, which I had to work up to, because I had not

232 Connor (1992), pp. 37-40.

${ }^{233}$ See Ruawai District High School 75th Jubilee 1929-2004, Jubilee booklet, p. 4; McLeod, V. (1991). Memories of Ruawai, Tokatoka \& Rehia. [Dargaville, NZ]: North Auckland Times. 
completed enough service to qualify for the top-salaried position I had won on merit. The Primary School Inspectorate arranged two days of in-service training for me at the large May Road Primary School in Auckland.

As I reflected on my appointment I realised that I was in a very unusual situation. I was seen as Maori. I was female Maori/Pakeha. I was twenty-three years old. Very few, if any, similar appointments were made during the 1950s. With Oscar and Thelma Holyoake as my mentors, I was launched onto the top of the Senior Teacher promotion ladder. I was trained in the position, as they saw it. I recall Thelma Holyoake saying, 'You will never have any friends of your own age now because of your promotion.' As already stated, I was hard working, adaptable and extremely fortunate.

I arrived at Ruawai by New Zealand Road Services bus and went to the Holyoakes' home. The person who normally boarded the Infant Mistress was telephoned about my arrival. On being told that the new teacher was Maori, I heard a fluting voice say, 'Oh-h-h-h-h. I couldn't possibly have a Maori girl. After all I do a lot of entertaining.' Racism was alive and well. The Holyoakes found an elderly widow, Mrs Jones, whose husband had been the blacksmith. She took me in temporarily, looked after me and cooked delicious old-fashioned steak and kidney puddings. We shared much laughter and history about her husband's Albertlander connections and early Ruawai families, until a flat for teachers became available in the township above the local General Store. On reflection, Mrs Jones, like Mrs Hansen at Te Tii, reminded me of our mother.

Ruawai DHS was serviced by ten bus runs. The teacher drivers lived at the end of the bus routes in New Zealand Department of Education or farm accommodation. Most drove two runs night and morning and arrived at school between $8.30 \mathrm{am}$ and $9.30 \mathrm{am}$. They then taught full-time while the buses were serviced daily at the onsite school garage. School hours were from 9.30 am until $3.30 \mathrm{pm}$. All going well, the last bus on a second run left the school at $4.30 \mathrm{pm}$. This meant a heavy teaching load, out-of-school preparation of required work plans, schemes of work for the year, blackboard work, marking, and making of equipment. All teachers not driving 
buses were rostered for playground supervision, from the arrival of the first morning bus, through intervals and lunch breaks, until the last bus left in the afternoon. Wet or fine, teachers perambulated the 'playground', corridors and classrooms. For some five-year-old children, it was a very long day.

About ten to twenty new entrants were enrolled, after their fifth birthday, twice each term during the three-term year. One spring day 33 arrived! They included fiveyear-olds with special needs, physical, vision and hearing impairments, or English as a second language. For sheer survival teaching in large infant classes tended to be more traditional and instructional, with aspects of the developmental 'play' session being added as teachers became more familiar with that new approach. Apart from the Janet and John Readers supplied by the New Zealand Department of Education, according to roll numbers from 1950, and the supplementary readers we funded through our library grants, we still relied on our own innovative and creative skills. Corporal punishment was still in vogue. Teachers stoked the classroom fires that provided heating in winter. A Dental Clinic and Manual Training Centre were on site.

Class numbers went to well over 40. Probationary Assistant (PA) classes were, under regulation, held at 35 pupils maximum. My PA was housed in a converted cloakroom on the opposite side of the school from me. Teacher and children filled the space. A second adult caused severe problems. To get into the room, I had to go like Jack Horner into a back corner with the row of hand basins while 30 children were packed in, then the teacher leaned against the wall in the front corner and the door closed. Imagine the performance just to close the door when a school inspector came!

One frantic morning when two teachers were absent, a parent, a music teacher and accompanist of international repute, arrived with her five-year-old daughter. She saw what was happening and offered to help out. Unlike now, parents were not encouraged into the crowded classrooms, and apart from the Headmaster's wife, relievers were impossible to find. Unfortunately the children were denied the experience of musical expertise, and classes were split amongst the other over- 
worked staff. The same woman taught me to play the piano in one-hour lessons on Monday evenings, and then I had an inspiring private concert of classical music when she played to me for an hour. Most schools had a piano. For a year, Monday to Friday, I practised the piano for two hours every morning before school started.

On reflection, I realised how privileged I was to have had the opportunity to acquire a skill that I was able to share with many young children after I left Ruawai. I also remember each day being a series of physical, mental and emotional workouts from daylight to dark. Unusually, I had not worked as an Assistant Teacher in a permanent position for any length of time. Embarrassingly young, I had many corners knocked off, and was reshaped on a very fast learning curve after promotion to my first senior position. It was extremely rewarding and enjoyable.

My reflections bring to mind many treasured memories of Ruawai, despite the experience of racism initially directed at me by a lesser being. The vice-regal visit by Lord and Lady Cobham. ${ }^{234}$ The mentors who opened their home and beach house to me for weekends, dug toheroa with me, and encouraged me to continue to expand my historical book collection then in its infancy. The interesting woman with the gecko collection and an attic full of carefully stacked, catalogued, old newspapers. The teacher whose husband taught me to drive a Ford Zephyr and then sent me off to Auckland to get a driving licence. The woodwork teacher who taught the evening hobby class, and suffered our swearing and cursing when tools and timber inadvertently went in different directions. The Dargaville sharemilking couple who, when growing up, knew my parents, found me via rumour, and with whom I spent a great deal of time. They also organised the purchase of my first car, a green Austin A35, which served me very well. The unexpected spontaneous farewell evening from a group of parents. ${ }^{235}$ Fortuitously, my unplanned fast tracking fitted well with my intention not to live the lifestyle my mother had, but to be independent as she had wanted me to be.

\footnotetext{
${ }^{234}$ Ruawai District High School 75th Jubilee 1929-2004, p. 49.

235 Ruawai District High School 75th Jubilee 1929-2004, pp. 46-49.
} 
While I was at Ruawai, a national referendum was held to change the numerical grading system for the Appointment and Promotion of Teachers to a reports system according to seniority, with white reports for Assistant Teachers, green reports for Senior Teachers, and yellow reports for Head Teachers/Principals. When the new promotion system was brought in, I had not completed the required years of service for the senior position high green report I was given. I chose to go off the graded list. To move across similar appointments in large city schools, I had that report confirmed for each application.

KNighton RoAD School, Hamilton

I was Infant Mistress at Knighton Road School in Hamilton city from 1960 to 1963. The Ruakura Research Station, with the newly-opened Waikato University and Hamilton Teachers' College, also in its infancy, were close by. Teacher trainees came to the school for their teaching experience sections.

URbanisation And The Hunn Report

Intense Maori urbanisation in 1960 drew a government response to 'investigating the state of Maoridom'.236 The 1960 Hunn Report on the review of the Department of Maori Affairs and its operational structures was that response. ${ }^{237}$ New policy was required, it stated, to progress Maori from an assimilation policy to a policy of integration, 'for Maori people as defined by the state.....constructing Maori people as a politically and economically controllable group'.238 [italics in original]

An accounting of Maori human and material assets was necessary. The terms of reference' called 'for a new look at Maori affairs from every angle' [including] 'pace' and what was being done for Maori'.239 'Research teams' including 'other Departments' were set up to gather data and survey trends under categories of

236 Hill, R. S. (2009). Maori and the State: Crown-Maori Relations in New Zealand/Aotearoa, 1950 2000. Wellington: Victoria University Press, p. 89.

237 Hunn, J. K. (1961). Report on Department of Maori Affairs. Wellington: Government Printer.

238 Mead, L. T. Te R. (1996). Nga Aho O Te Kakahu Matauranga: The Multiple Layers of Struggle by Maori in Education. Unpublished PhD Thesis, University of Auckland, Auckand, p.348.

${ }^{239}$ Hunn, J. K. (1961), p.13. 
'Population'; 'Land' Settlement'; 'Housing'; 'Education'; 'Employment'; 'Health'; 'Land Titles'; 'Legal Differentiation'; and 'Crime'. Five 'premises' were put forward as a basis for future policy. Briefly, the general conclusions were that Maori had made 'remarkable progress over two generations', and that they should be 'fully integrated in another two'. The Department of Maori Affairs had 'achieved solid progress in land development, housing and welfare', but needed to redouble its activities' to 'cope with the explosive rate of population growth'. ${ }^{240}$

Official policy about the future of the Maori race had not been defined either by statute or by the Board of Maori Affairs, but neither could such policy divert the process of self-determination. 'Evolution' was 'clearly integrating Maori and Pakeha ... to combine (not fuse) the Maori and Pakeha elements to form one nation wherein Maori culture remains distinct,' implying 'some continuation of Maori culture'. ${ }^{241}$ In releasing the Report, the Minister of Maori Affairs, the Hon. J. Hannan, stated:

Many of the recommendations in the Hunn Report are of a farreaching nature and all have a fundamental bearing on the wellbeing of the Maori people, the well-being of New Zealanders as a whole, and on race relations in New Zealand. This makes it all the more imperative that the public should know the facts of the Maori situation. ${ }^{242}$

The study reached 84 conclusions. Twelve were related to Education, including, 'closer liaison between Departments of Education and Maori Affairs'; 'visiting status' for entry to Maori schools by Departmental Officers; the need for 'Maori Kindergartens and Play Centres'; 'Research [of] Maori education problems'; 'intelligence tests for Maori'; 'special training' for Education Board teachers to cater for Maori pupils; use of 'Visiting Teachers', as in Education Board schools, for home visits with Maori; targeting of 'high ability Maori children' to continue secondary education to 'School Certificate and University Entrance Examinations'; 'educational guidance on entry to post primary schools' and 'vocational guidance at the school leaving age'; 'tuition in Mathematics' as preparation for trade training and apprenticeships; and a 'five-yearly review of Maori Schools suitable 'for

\footnotetext{
240 Hunn (1961), p. 14.

241 Hunn (1961), p. 15.

242 Hannan (Foreword) in Hunn (1961), p. 3.
} 
transfer to Education Board control'. A Maori Education Foundation should be established 'to finance a full post-primary and university education and scholarships for Maori'.243

For me, being educated at the local public primary school and New Plymouth Girls' High School differed from the Hunn Report conclusions for Maori in Maori Schools, because our mother and father expected we would follow the same track of primary and secondary schooling opportunities as other families in Waitara. We were not to be treated any differently because we were Maori. Nor were we to be sent to Maori boarding schools. I was enrolled at Waitara District School and New Plymouth Girls' High School as Kura Taylor, and in time I became a striking example of a Pakeha educated, well-assimilated, integrated, English speaking brown Pakeha with an ability to spontaneously reshape as Maori or Pakeha, or Maori/Pakeha, according to the dialogic encounter in which I was operating at any specific time. I did not have to think about reshaping because the process was so spontaneous, and met the education policy of expected integration outcomes as the state required and as our parents wanted for us.

HENDERSON NoRTh SCHOOL, AUCKLAND

From 1963-1967 I was Senior Teacher (Junior Classes) at Henderson North School in West Auckland. The hustle and bustle of Auckland was a far cry from the quiet rural life at Ruawai and the slower urban tempo of Hamilton. More important to me, I was able to access a feast of live theatre shows, musicals, operas and orchestral concerts by exceptional international and New Zealand artists.

\section{Papatoetoe West School}

I was appointed Supervisor of Junior Classes at Papatoetoe West School 1967-1969. In the two years I was there I became actively involved in the local Infant Mistress Association, and began my political interest with the NZEI Papatoetoe Branch Managing Committee.

243 Hunn (1961), pp. 5-6. 


\section{CoRnWALl PARK PRIMARY SCHOOL 1969-1988}

Cornwall Park Primary School opened in 1921. The Infant School was completed in 1928 to accommodate increased enrolment, and by 1938 three more rooms were added to the Infant School. It was in this building that I spent almost twenty very fulfilling years. I also became much more active in the Auckland Branch of NZEI. I was Associate Principal (Junior Classes) at Cornwall Park School from 1969 to 1987. The school was located in a high socio-economic inner-Auckland suburban area. Throughout the 1960s and 1970s the school roll fluctuated, and we were never sure whether the roll would be closed or restricted, or if the school zone would be reviewed. The Principal, Jack Oliver, and successive School Committees negotiated very strongly with the Auckland Education Board and the Department of Education about roll numbers, the state of the original high-ceilinged, wooden oil-floored buildings, and a re-build. The school site, originally in the Cornwall Park Estate, is physically exceptional. The school grounds with their mature trees, provided shade and opportunities for Nature Study and Science exploration. We could see all the seasonal changes and various small creatures on site in very close proximity. We could also view the motorcades of important people who passed the school on their way into the city, providing much excitement and conversation that translated into news sheets for reading.

\section{FLAG CEREMONy}

The Annual School Flag Ceremony ${ }^{244}$ and prize-giving stands out as being the one event that is nationally distinctive to Cornwall Park School (now known as Cornwall Park District School). Beginning with a sports programme, the ceremony was also the farewell to the Standard Four children moving on to Remuera Intermediate School. The impressive world flag collection, started by the first Headmaster, $\mathrm{Mr}$ Birss, in 1921, was housed in glass-fronted display cabinets in the main school

\footnotetext{
244 See Cornwall Park School, 75th Jubilee 1921-1996, Jubilee booklet. Available at https://cornwallpark.school.nz/history/
} 
entrance foyer. As a country became independent, their new flag was added and the old flag retained. If boundaries and country names changed, old and new flags of those countries were part of the collection. Sometimes flags were loaned out for various community events. I recall there were always requests to carry a certain flag, because it was the one that a child's grandad, grandma, dad, mum, uncle, aunty, brother, sister or cousin had carried in their time. ${ }^{245}$ Sometimes requests were made for philosophical, ideological, or cultural reasons. We practised so hard for the ceremony. Lines evenly spaced, arms swinging, heads up, we marched proudly to a drum that reverberated across the community.

On the day the children, parents and teachers were really proud to be part of this important ceremonial occasion. Pairs of Junior Class children, led by a flag bearer, marched on to the field with their teachers, supported by much applause from proud parents, and stood to attention in their special area. The Junior Classes always carried a small New Zealand flag, but then it disappeared just before a ceremony. There were no other flags small enough for the young children to manage, especially in the wind. So the night before the ceremony I made a small Cornwall Park School flag in the school colours, with the school badge, and that was carried for many years. We did not tell anyone who the flag bearer would be until the day. The criterion for choosing was not about being the most advantaged or the best, but more about a child for whom this would be the one proud highlight in their life, that might help to turn that life around.

The Standard classes then marched on, followed by the Standard Four Flag Bearers in their particular formations to stand in two rectangles around all the classes. Invited guests were escorted by the colour party. Everyone stood to sing the national anthem. Flowers were presented, flags lowered and everyone sat, parents along the terraces, teachers with classes on the grass field. Speeches were made, prizes presented and recipients applauded. The Standard Four Flag Bearers then

245 Cornwall Park School, 75 th Jubilee 1921-1996. 
marched to form a guard of honour and the colour party escorted the invited guests off, before the Standards marched off followed by the Juniors.

My reflections of the Flag Ceremony are of the Standard Four girls and boys proudly carrying the flags and all the children marching with great pride, while parents spontaneously applauded. The ceremony was always very, very impressive.

\section{Class Sizes ANd Staffing}

Classes were large at Cornwall Park School. The Junior Classes staff were usually young and inexperienced. I remember one year when there were five classes and an entirely new staff, consisting of one Probationary Assistant and four young recently certificated teachers, one of whom had an MA (Hons) degree. They were bonded for two years following their Probationary Assistant year. None had experienced a class size of more than fourteen. Cornwall Park School classes were up to 39 , with 29 for the PA at the beginning of the year. We sat in my classroom and chatted. I looked around at their bright, expectant faces, and said, 'Well, these are the class lists. Have a look at them. You choose. I'll be back.' I placed the lists on the table and left. They took five minutes to decide amongst themselves. I thought that boded well for the coming year.

Cornwall Park School demanded traditional high standards. Excellence in oracy, literacy, and numeracy was the expected norm. Speaking at the School's $75^{\text {th }}$ anniversary in 1996, the Principal, Peter Ellery, stressed a 'legacy of quality [and] academic excellence'. ${ }^{246}$

Cultural pursuits were also prominent. In addition to the general staff, two highly talented teachers for Music and Art were appointed to work across the school. We participated in quality musical happenings, singing and dancing on the field until the school hall was built. I recall one event when about two hundred junior classes

246 Ellery, P. [Principal of Cornwall Park School] (1996), quoted in Cornwall Park School 75th Jubilee 1921-1996. 
children particularly enjoyed dancing with their parents and teachers on the playing field. The school hall later provided a venue for high quality musical performances.

\section{PARENT INVOLVEMENT}

Under the Infant School were four basements, two of which were classroom size. We cleared one out, and with a tap nearby, we had our Art and Craft space. We eventually managed to get a teacher into Marie Clay's Reading Recovery Training Programme, to support early readers who 'needed to learn skills and strategies to assist their reading development'. ${ }^{247}$ We were fortunate and appreciative to have sound Parent volunteers who supported our reading and writing programmes. Twice each year, written and oral reporting to parents took place. I recall there was always 95-100\% attendance. Parents also ran the very profitable school gala fundraising event each year. A second basement was cleared to house the gala day contributions. I remember the excitement of the junior classes, partnered in two long unending orderly lines, as they carried countless books and magazines up into a classroom for the gala day bookstall.

\section{Social Welfare Reception CENTRE}

A Department of Social Welfare Children's Residential Care facility was located in the school zone. The children who came from there added an interesting different dimension to the school. I believe that being in the Cornwall Park School environment, even for a short time, was a considerable plus for their all-round development and social adjustment. The school's Maori caretakers were also very helpful with any children for whom brief times outside the classroom provided an active success base for reading and writing. ${ }^{248}$ This was important, because children who were recorded as failing began to perform better. The astute Principal realised that there were conflicting cultural views with some Pakeha agency personnel, and one of my extra responsibilities was to be the Principal's 'Magician'.

247 May (2011), p. 186.

248 Taylor, K.M. [n.d.] Massey University assignment on Learning Disabilities. Unpublished ms, in author's possession. Samples of individual reading booklets compiled with the children are held in the author's collection. 
Whakapapa went with me to visit the families of Maori and Pacific Island children to perform 'magic', when such visits were seen as helpful to children's learning.

\section{REFURBished ClassRooms}

I recall a decision that wet and dry areas would be an advantage, and sinks were installed in the classrooms. A dry area was to be carpet-tiled in colours already selected by the Education Board and laid overnight. After the first three rooms were done, I asked if my classroom was going to be like the others, and how the oiled floor was to be cleaned before the tiles were laid, but was told no cleaning was required. I was getting dark brown carpet tiles and beige hessian boards on the walls. I said, 'Brown teacher, brown children, brown display boards, brown floor, brown carpet tiles equals brown spot at Cornwall Park School? I don't think so.' I was able to negotiate a beautiful blue hessian wallboard that provided a suitable sea and sky background for children's murals and art displays. Fire exits from each classroom were also built along the front of the building. Before the new School Hall was completed, we had a spectacular musical Easter Bonnet Parade in and out of those exits, up and down the steps, singing and dancing out into the playground to greet the parents.

Along the road side of the building there was a wide corridor, staff room and toilet. Later, because all teachers used the bigger staff room in the main classroom block, the Junior staff room became an all-purpose room and, later still, a useful Junior Classes Library area. The corridor provided hanging space for bags and coats, absorbing the southerly cold in the winter and the traffic noise all year round. When the weather was wet the corridor was a place to have lunches, so that we could air out the classrooms and then clean and sweep up while the children went either outside for a short time or back into the classroom to engage in quiet individual or group activities. The corridor also provided readily accessible space for housing shelves of boxed supplementary readers. The children's toilets were in a separate block outside. 


\section{FAMILY BEREAVEMENTS}

In 1969 and 1973, I experienced the deep trauma of family deaths. In 1969 our father called us all home and told us that he had cancer and had been given six months to live. We were instructed to go about our business, and when our mother called us we were to come home. We did just that. I remember the whangai children our mother cared for bringing their Pakeha friends to tell our father what they had been doing as he lay at home. Four years later, after a series of major operations, and refusing to have a fifth, our mother also went to the hospice with cancer. I looked after the home front while my older sister sat with mother. A week later she died, and we brought her home too. ${ }^{249}$ As with our father, I again experienced Maori practical common sense grieving and the supportive rallying around of wider family and friends. I recall very clearly the ululation of the karanga, the calling, when the old Maori people whom our mother and father had known came on each occasion to pay their last respects. I remember the extraordinary work done in the kitchen and the endless food preparation. I remember, the night before the burials, the old people sitting with us, joking, laughing, singing, remembering fun times with our parents. I was instructed to 'Put the flowers outside darling, so the dew will keep them fresh for tomorrow to go to the cemetery'. That is what we do at those times.

In reflection, I continue to speak with our mother and father about what I think they would like to know. I also include past relatives and very close past friends in the same process from time to time. Over the years I have practised speeches to them as well. In 1976 I bought my own home in Auckland in a desirable Pakeha suburb, where I am now surrounded with, and enjoy, tangible reminders of my earlier years, and there I, like other Maori I know, converse with my dead. It is what we do. Michael King writes of Maori speaking to the dead, and his experience of a Maori woman recognising a photographic image and speaking to the person as if she were still alive. ${ }^{250}$ As I reflect upon the deaths of my parents, I am reminded of the Maori,

\footnotetext{
249 Sympathy correspondence and cards held in author's collection.

250 King (2004), p. 86.
} 
Pakeha and Teacher support networks which come smoothly into play at those times. I was very comforted. I experienced real compassion in my workplace, from my friends and at home from my relatives. I knew how fortunate I was to have been born a daughter of my parents.

\section{FirST DEGREE AND AWARD}

My earlier undergraduate study began in 1979, when I enrolled extramurally at Massey University to complete my Bachelor of Education degree in 1987. I was our first family graduate. Further study did not attract a higher salary at that time, and was not an employment requirement. When I reflect upon my achievement, I realise what a long hard road studying and carrying Senior Teacher responsibilities really had been. To prepare for later degree study, I decided to complete the New Start Course at the University of Auckland. I viewed a second degree for me, bordering on retirement, as relaxed learning to be fully enjoyed during my Third Age.

While I was at Cornwall Park School, as the first Maori/Pakeha woman teacher, I received the honour of being made a Fellow of the NZEI at the Centennial Awards Dinner in Wellington in 1983. I than had the double honour of being invited by the National President to respond on behalf of the group of Fellows that evening. 251

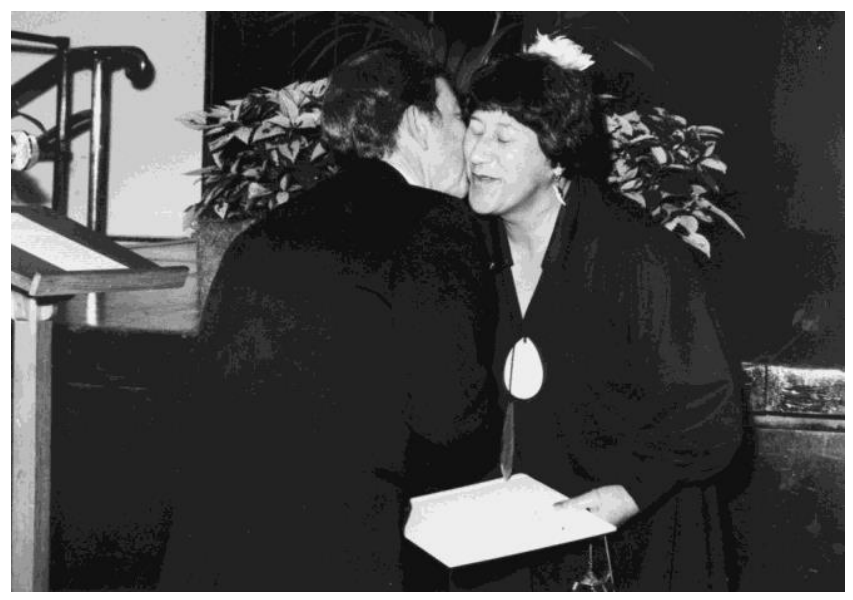

Figure 4. Kura Marie Teira Taylor receiving the honour of Fellow of NZEI, 1983.

\footnotetext{
251 NZEI, correspondence with author, 16 March 1983; photographs, cards and letters of
} acknowledgement in author's collection. See also Connor (1992), pp. 46-47. 
By 1987 the Cornwall Park School roll was falling, and this impacted upon the school's staffing entitlement, and the status and salary of my position as Assistant Principal (Junior Classes). A school rebuild was inevitable. Retirement was two years away. I was notified as being on transfer, and given salary protection for two years, and priority right of appointment. ${ }^{252}$ I was faced with three options, and a very difficult decision. The first was to stay in my known niche at Cornwall Park School on a much reduced salary, and retire on reduced superannuation. The second was to stay at Cornwall Park School with the same Senior Teacher responsibilities at a much reduced salary, and contribute to superannuation at a higher rate. The third option was to move to another school and retain my full salary and full superannuation. In the uncertain climate, I had no choice. Reluctantly, in my twentieth year at Cornwall Park School I moved to safeguard both my salary and my superannuation.

Cornwall Park School had been rebuilt by 1992. All that remained of the old traditional construction were bricks used in the modern landscaping, the school bell and, overlooking the playing field, the tiered stone terraces constructed by prisoners during the Depression. The old Infant School that I knew had been demolished and replaced by a 25 metre swimming pool. One thoughtful teacher surprisingly presented me with the two brass window pole openers for the old high windows, as a memento of my morning classroom visits.

In 1996 the school celebrated its $75^{\text {th }}$ Jubilee. So much stands out about Cornwall Park School that it would need a thesis on its own to do it justice. As the then Principal, Peter Ellery, stated:

Our legacy of quality has been carefully nurtured with pride and humility these past seventy-five years. Our motto 'Honour not Honours', visioned by the first Headmaster Mr Birss, reflects living traditions upheld by successive generations of students, staff, parents, and the school-wide community ... the tradition of excellence lives on ... the best of the school's proud past is still integrated into the present.253

\footnotetext{
252 General Manager, Auckland Education Board, correspondence with author, 21 September 1987. ${ }^{253}$ Ellery (1996).
} 
As I reflected on my years at Cornwall Park School, I knew how privileged I was to have been able to work for almost twenty years with a Principal of Jack Oliver's calibre, as well as with many extremely competent, well-trained young teachers, and the parents and the children from the Cornwall Park School district.

\section{DAWSON PRIMARY SCHOOL}

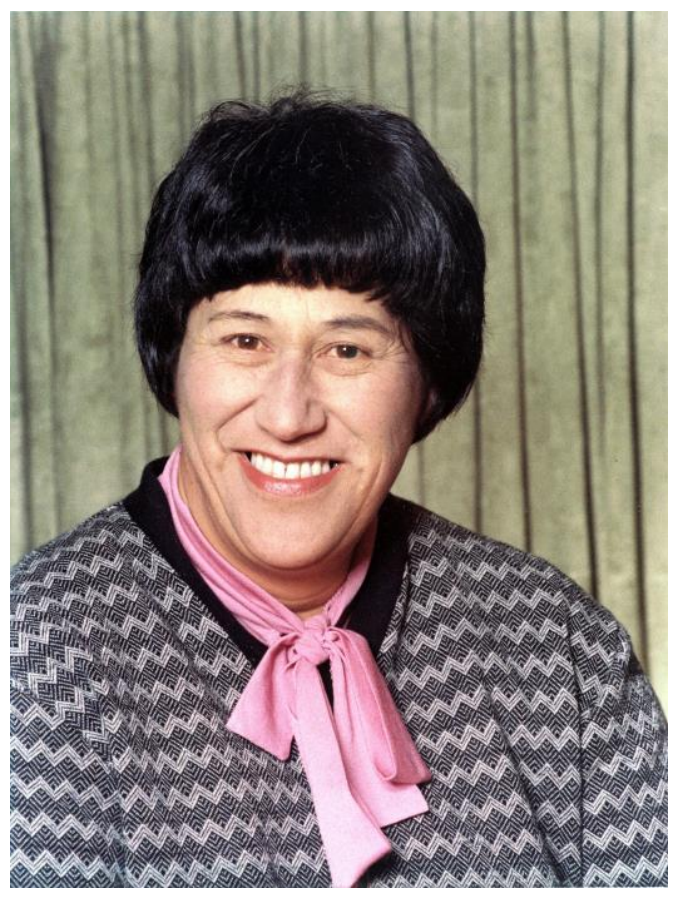

Figure 5. Kura Marie Teira Taylor, Assistant Principal, Dawson Primary School, Otara, South Auckland, 1988.

In 1988, I was appointed Assistant Principal (Junior Classes) at multicultural Dawson Primary School, located in a low socio-economic area of new state and lowcost group housing in South Auckland. In total contrast to Cornwall Park School, the roll was '67\% Pacific Island, 26\% Maori and 7\% other ethnic groups'. ${ }^{254}$ Most families owned their own homes, so there was a high degree of community permanency and stability. Being new to the area, I first went to visit a quiet unassuming Maori woman whom I knew through the Maori Women's Welfare League. As was usual on a first visit to a new home, I took a koha, gift, of four jars of

254 Connor (1992), p. 42. 
home preserved peaches. She heard the clink of glass upon glass and promptly said, 'We don't drink.' What a refreshing contrast to the Pakeha stereotype of Maori.

Dawson Primary School's environment was totally different, physically and culturally, from schools I had previously enjoyed working in; but the classes were much smaller. I heard command-type language used with children in tones I had not heard since the early 1950s, back in Maori Schools, rather than the conversational tone and type of interaction to which I had become accustomed. Isolating children out of sight outside the classroom for behavioural reasons was also an issue. There was a great deal to do in terms of relationships, learning expectations and rewards. I was the only teacher on the staff with a university degree, holding Ministerial appointments, and who had been a Research Affiliate at the University of Auckland. I had an impression that I was seen by Pakeha teachers only as one of the brown masses, not as a successful teacher and the highest qualified professional on the staff.

I first discussed with my staff, two Pacific Island and three Pakeha teachers, how we could utilise my skills. They wanted time to test reading levels. I supported them but, at their request, had to complete the demanding task myself. I graphed the results of children's reading levels tests and three months later repeated the process. We compared the results. A large number of children were reading well below age level for their time at school. The only differences I could see between Cornwall Park and Dawson children were ethnicity and teacher expectation. To me, both sets of parents wanted the same things for their children: to do well and be able to read. I was seen as a threat. When a staff member left to take up a senior position in a similar school, I asked her why she was leaving. She replied, "All the time you have been here you have asked us professional questions that we can't answer and no one else has helped us answer. I used to shudder because I knew you were going to come and ask us something else.' 'Oh dear,' I said. 'Only one a week! I asked a question every day at Cornwall Park School.'255

255 Connor (1992), p. 43. 
Written reports to parents was also a contentious issue. I refused to sign the first batch, explaining my reasons individually while conversing about positive suggestions. I asked my staff to think about what they had written and the interpretation of their words arranged in their particular way. 'Could do better', 'Could try harder', or negative comments were not options. I talked with them about the opportunity for parents to understand their children's progress. All reports were re-written. Parent/teacher discussions were another consideration. I recall casually asking a Maori mother if she realised that her six-year-old was a bright child who could go to university later on? A Pakeha staff member overheard us and asked why I had spoken to the parent like that. I asked, 'What do you mean? Isn't that how you speak to your children, sowing the seed of continuing learning? What is the difference?' There was no response.

When the Principal retired, I applied unsuccessfully for the position. The new Pakeha middle class male appointee showed no apparent knowledge or appreciation of Maori or Pacific Island cultures and languages. He demanded that I give up my Ministerial appointments, which Cornwall Park School had seen as kudos for the school, and announced his determination to turn Dawson into the Remuera of Otara. ${ }^{256}$ Assimilation and racism were to thrive. I used up my accumulated sick leave and retired with dignity from 1 February 1991 on full superannuation. Interestingly, I had encountered overt racism when I was promoted to my first senior position at Ruawai District High School, and again on completing forty years of teaching service at Dawson School.

256 Connor (1992), p. 44. 


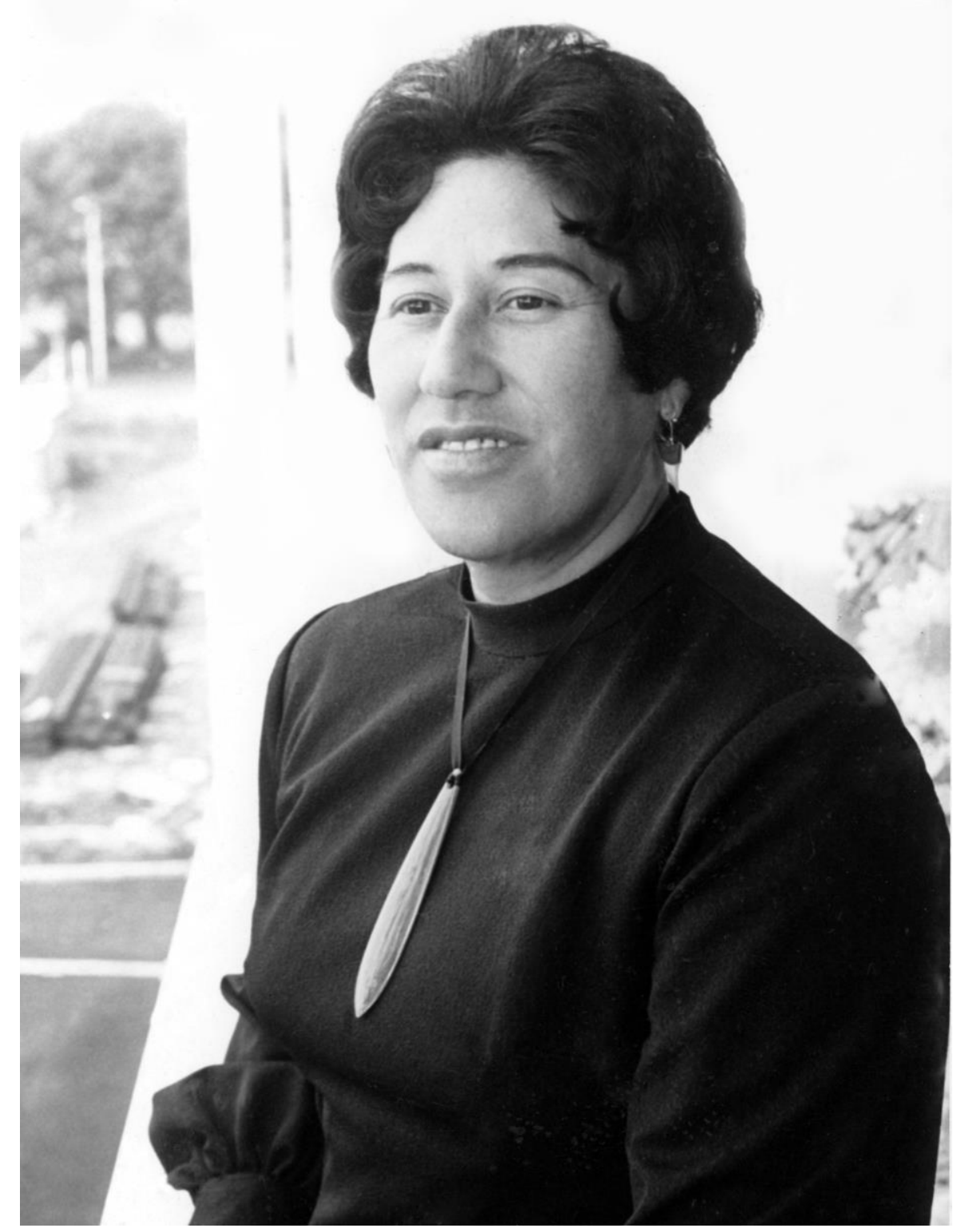

Figure 6. Kura Marie Taylor, 1974, aged 42 years, the year she became the first Maori woman to be elected as the President of the Auckland branch of NZEI.

The organisation which has been the most influential in politicising me during my years of 'Playing the Games' is the NZEI. ${ }^{257}$ Very few women, and even fewer Maori, attended the NZEI Branch Meetings or Annual Meetings at the time I became most active. The face of the Institute was predominantly white male. I was invited to chair an early national NZEI committee, Education for Equality. A report to Annual

257 Connor (1992), pp. 48-52; Roth and Hammond (1981), pp. 48-155. 
Meeting was produced in the field of affirmative action for women that became the basis of NZEI policy, and was reported on annually.

Three major events characterise those years of my NZEI experiences: the 1975 Auckland NZEI Centennial World Education Conference; Te Tatai Hono, the 1982 NZEI Report and Recommendations on Maori Education; 258 and the 1981 UNESCO World Confederation of the Organisations of the Teaching Profession (WCOTP) Consultation on Peace and Human Rights, held in Morges, Switzerland. A plethora of employment related activities and committees were interwoven with these events.

\section{AuCKLAnd NZEI CEntennial World EduCATion ConfEREnCE, 1975}

In 1975, the Auckland Teachers' Institute extended over the whole of the Auckland province, from the North Cape down to Gisborne on the east coast and across to Taumaranui, then to Mercer on the west coast of the North Island. In later years, as new branches were set up, the Auckland Branch of NZEI became a much smaller branch in a more densely populated Auckland urban area.

The Auckland Teachers' Institute joined with Wellington, Nelson, Canterbury and Otago in 1893. The merger resulted in the formation of a national body, the New Zealand Educational Institute (NZEI), which was officially recognised in the Public School Teachers Incorporation and Court of Appeal Act in 1895.259

The NZEI represented teachers' professional concerns and questioned working conditions from 1893, aiming: 'To advance the cause of education generally whilst upholding and maintaining the just claims of members individually and collectively.'260 The NZEI is non-political, but did question state actions that appeared to teachers to erode quality education. It was the driving force behind changes to official education policies for New Zealand Primary and Intermediate

${ }^{258}$ NZEI (1982). Te Tatai Hono: Report and Recommendations on Maori Education. Wellington: NZEI. ${ }^{259}$ See Simmonds (1983), pp. 1-43.

${ }^{260}$ Bell, K. (1976). Education in Change. In NZEI, Education: A Selection of Papers from Auckland Centennial World Education Conference, 1975. Auckland: Abco Press Ltd., p. 8. 
Schools. The NZEI Annual Meeting, attended by branch representatives, determined NZEI policies.

I was elected Auckland Branch President in 1974 on a postal ballot of members. The historical milestone of the Auckland centenary in 1975 was marked by holding the 1975 NZEI Annual Meeting in Auckland. That year the Auckland Branch welcomed retired members to its Branch Annual and General Meeting. The concept for the World Education Conference was the brainchild of the national Vice President, Kelvin Bell, National President-elect for 1975. The aim of the Conference, as a dynamic professional opportunity of world standard, was to expose teachers to professional ideas on an international stage. Improving teachers' ability to teach, in order to produce greater gains in learning, was the Auckland NZEI launching pad into its second century.

The idea was approved by the Auckland Branch Management Committee, and in 1974 the conference was organised on a \$10 loan from a Headmaster and a tight budget. We negotiated with the Chairman of the Auckland Education Board for the release of School Liaison Teachers to involve and communicate with schools. This was the beginning of the School Liaison Teacher system in NZEI Auckland Branch schools. Working committees, venues, sponsorships, local and international speakers, workshops, accommodation, travel, advertising, printing and public relations were successfully accomplished. Key speakers from New York, Los Angeles, Syracuse, Sydney and Florida were invited, and sponsored through negotiation with various businesses associated with education.

The Auckland War Memorial Museum Council extended NZEI the honour of allowing the powhiri, traditional welcome to visitors, and whaikorero, welcoming speeches and responses, to take place in the Museum's Maori Court. An official reception and social mingling followed. A Centennial Banquet and Pacific Farewell were held at other city venues.

The conference was held at Ellerslie Raceway, Auckland, together with an International Exhibition of Children's Work and Trade Fair, while Te Puea Marae, 
Mangere, provided a fitting location for a curriculum focus on ethnic minorities. Six topic areas of change - Curriculum, Teaching Strategies, Language, Social Studies, Children's Needs, and Administration, with up to six sessions on each topic - were arranged by Chairpersons with small committees. Four special Community sessions involving international and local speakers were open to parents and interested others.

The Hospitality Committee assisted with reception and registration; the official opening reception; the Centennial Banquet; the Pacific Farewell; flowers and gifts to key speakers; and in-conference tours and trips for partners. Due to able leadership, the calibre of the organising committee of five, the topic and hospitality committees, and the commitment to positive relationships amongst all those in front of and behind the scenes, the conference was an outstanding success. A conference book of papers was produced, ${ }^{261}$ the $\$ 10$ loan repaid and a profit made. The conference was a tribute to NZEI and everyone who was involved in any way.

\section{Te Tatai Hono, NZEI Report And Recommendations On MaORI EDUCATION, 1981-1982}

In 1967 the NZEI's first report on Maori Education was presented to the Annual Meeting. The committee brief was to: produce a comprehensive list of objectives for negotiation; increase interest in improving the lot of the Maori child; ensure increasing liaison between agencies and communities; and consider a wider framework from pre-school to vocational training. ${ }^{262}$ The committee members gained a high profile in the world of education and academia.

In 1979 the second NZEI Consultative Committee on Maori Education was set up. Its terms of reference were to: review existing policy; consider developments since 1967; and prepare a report for the 1982 Annual Meeting. The committee, broadly representative of teachers and communities, was predominantly Maori. It elected a Pakeha workaholic Chairperson who was a fluent speaker of Te Reo Maori, Maori

\footnotetext{
261 NZEI (1976).

262 NZEI (1967). Report and Recommendations on Maori Education. Wellington: NZEI, p. 7.
} 
language, comfortable with Maori beliefs and ways of doing and knowing, and familiar with Maori and Pakeha meeting and discussion procedures.

In 1981, fourteen years on from the first report, Te Tatai Hono was born. Receiving oral submissions from Maori meant sitting until the presentation was over, sometimes until $1 \mathrm{am}$. Submissions were received, sorted and sifted. I was coauthor with the Chairman, and recorder of proceedings. Finally the report was ready for its ceremonial launching at the 1982 NZEI Annual Meeting. ${ }^{263}$ The Christchurch venue reverberated to the Karanga, the call announcing the arrival of the report for presentation. All but one of the 26 recommendations were accepted by the Annual Meeting in full session. Later I recall being challenged by a Maori male teacher about the equal opportunity comment in the report. My contention was that equal opportunity in New Zealand was open to all. The problem was getting through the Pakeha gate-keeping to access the opportunity. Te Tatai Hono became the NZEI negotiating instrument for Maori Education for many years.

\section{UNESCO/WCOTP Consultation, Morges, SWitzerLand, 1981}

In his history of the NZEI, Ted Simmonds reported that:

In [June/July] 1981 the Auckland branch secretary, Miss Kura Marie Taylor, went to Switzerland to attend a joint WCOTP/UNESCO Consultation of Specialists on Education for Peace and Respect for Human Rights - two issues which have increasingly concerned WCOTP in recent years. She had the honour of being elected unopposed as president of the meeting, which involved 15 specialists from 14 countries. ${ }^{264}$

Being the first Maori/Pakeha woman teacher in one hundred years to attend an international conference as the NZEI nominee was indeed a very special honour and privilege. Before I left, I had to deal with six weeks of full-time classroom teaching with senior responsibilities; completion of 1500 word assignments for Massey University; a three-hour Advanced Diploma in Teaching examination; initiating an Acting Secretary for the Auckland Branch, one of the largest NZEI branches; and

263 NZEI (1982). Te Tatai Hono: Report and Recommendations on Maori Education. Wellington: NZEI. 264 Simmonds (1983), p. 243. 
securing my home. Time passed. I thought it was all a dream that happened to other people. I would not be going to Switzerland. However, the nomination was confirmed by the Secretary-General of WCOTP in a letter dated 6 April 1981. The Institute machinery moved into action and all was organised, including my new passport and CV. The Principal and my staff at Cornwall Park School were highly supportive. Fortunately I was able to arrange an excellent, skilled, relieving teacher who just happened to be Maori, was available and was experienced in teaching large classes of new entrant five-year-olds.

The most frightening thing of all for me was being told at my final briefing with the NZEI National Secretary, Jack Smith, 'You are not representing anyone! Not the NZEI, not Maori, not women, not teachers! When you get on that plane you ARE the Institute!'

It was my first really important conference, and it was also necessary for me to follow Maori protocol related to the recognition of the host organisation in the form of a koha, gift. My predicament became quietly known via the runners of the kumara, sweet potato vine. Maori women teachers and the Maori Women's Welfare League networks came to my rescue. A beautiful whakahuia, kauri feather container, was carved by Morgan Puru, and donated for presentation to WCOTP on behalf of the NZEI.265 Maori women teachers from a South Auckland School also donated various small give-away gifts for consultation members. The Arahina Branch of the Maori Women's Welfare League gave me New Zealand desk flags with stands. Maori teacher and artist Toi Maihi designed and produced business cards, and screen-printed distinctive scarves. Two friends, artist Ramai Hayward and teacher Mahia Wilson, loaned garments featuring Maori design patterns. The NZEI library and the NZ Foundation for Peace Studies provided discussion notes and a wide range of background papers. Auckland College of Education Maori academics and the Auckland Race Relations Office assisted in the preparation of a conference

265 Taylor, K. M. (1982). 'Maori Woman Teacher represents NZ at Switzerland Conference'. Tu Tangata Magazine, 4, February/March, p. 29. See also Taylor, K. M. (1981d). Presentation of Whakahuia on Behalf of NZEI, UNESCO/WCOTP Consultation on Peace and Human Rights, Morges, Switzerland, 29 June-3 July (reproduced in Connor, D. H. (1992)). 
statement on peace and human rights. The Department of Maori Affairs assisted with a cash grant towards conference expenses. Both Maori Affairs and Race Relations personnel also welcomed me home.

Reflecting upon my preparations for the Consultation, I remain extremely grateful for the many spiritual as well as tangible expressions of support at that time. Maori were concerned that I was travelling alone, stating that I should be accompanied. I explained that I was comfortable travelling within the prestigious aura of the NZEI, and protected by the spirits of my Te Atiawa Tupuna under the aegis of Te Raukura 0 Te Atiawa feathers, the peace and goodwill symbol of Te Whiti O Rongomai.

Cornwall Park School Principal, Jack Oliver, together with staff, teachers, friends and NZEI members, farewelled me at Auckland International Airport. After a stopover in Hong Kong, I arrived in London for two days of jet lag recovery. Then I flew on to Geneva, where I was met by the WCOTP Secretary General, John Thompson, who drove me to Morges. Waiting for me in my hotel room was a warm welcoming letter from the NZEI wishing me well, and a copy of Te Tatai Hono, straight off the press.

WCOTP, under contract to UNESCO, organised the Consultation of fourteen specialists in wide ranging education fields, ${ }^{266}$ from Brazil, Denmark, France, German Democratic Republic, Guyana, Japan, Malta, Netherlands, New Zealand, Nigeria, Senegal, USA, USSR, and Yugoslavia. Three Observers came from Paris and Geneva Universities. The lone Co-ordinator was Australian, the Representative for UNESCO was Russian, and the WCOTP Secretary-General was English. ${ }^{267}$ Two women Consultant Secretaries were Swiss. A highly diverse range of practising teachers, teacher leaders and specialists, of whom only five were women, had been drawn from a broad spectrum of educational systems, from community to university, in industrial and developed countries. The first morning was devoted to introductions in the Consultation languages of French and English, with

266 WCOTP/CMOPE (1981). News Release, 3 July.

267 UNESCO/WCOTP Consultation List of Participants, Observers, and Representatives, 29 June-3 July, 1981. 
simultaneous translation. The majority of participants were multilingual. I stood out as the New Zealand Maori monolingual curiosity from far, far away.

Key papers on education for peace and respect for human rights were delivered by participants from Malta, Russia, Senegal, German Democratic Republic, and the Netherlands. ${ }^{268}$ In the afternoon, the Consultation President and Rapporteurs from Brazil and Nigeria were appointed. Due, I am certain, to the mana, prestige, and very high regard in which NZEI is held by the international education communities, I was appointed President of the Conference. I facilitated proceedings in the only way I knew, as the NZEI had taught me. I opened with a mihi, Maori greeting with English translation. Throughout the Consultation, I drew parallels with things New Zealand and Te Atiawa Iwi Maori as I knew them. The smattering of Maori I used caused too much consternation for the interpreters, so for their comfort I put Te Reo Maori aside during the business sessions and used Maori alongside the other languages only for ritual meeting, greeting and closing.

\section{Plenary SESSiOnS}

In the plenary and group sessions of relaxed positive relationships, the participants discussed key areas of pre-service and in-service teacher education, taking into account: interdisciplinary approaches to school curriculum; basic principles fundamental to education for peace, disarmament and human rights; and the application of curriculum content and method at different levels of learning, by different cultures, and in different subject areas. Of particular importance were positive school and community interaction inclusive of the development of attitudes to peace and human rights. The news release stated that:

The concerns of the people in the group coincided in their belief that only a concerted and orchestrated effort by educators in all fields and at all levels will produce the results which are sought by all teachers - peace and human rights, essential to the promotion of justice and truth which must be at the base of any sound educational system. ${ }^{269}$

\footnotetext{
268 For a list of the key papers, see Primary Sources: UNESCO/WCOTP.

269 WCOTP/CMOPE (1981). News Release, 3 July.
} 
In a personal statement on the consultation topic, I spoke of the NZEI code of, 'personal service to others through concern for and responsible promotion of the education and welfare of children, students, and teachers'. ${ }^{270}$ I commented on our distance from theatres of war, and how appreciative we were of the ways that our war dead were especially cared for in other countries. I spoke about the compulsory New Zealand education system for citizens aged six to fifteen years, the four official English/Maori bilingual schools, and Te Tatai Hono, just released by NZEI (ahead of its official 1982 launch). Consultation members expressed surprise that Te Reo Maori was not an official language in New Zealand at that time. I mentioned school control and administration, and how teachers, through consultation with government agencies, were able to influence the review and shaping of curriculum. I emphasised our belief in the skill of the teacher to teach. I noted various international education aid programmes which the New Zealand government supported. I talked about the welfare state and its support structures. I stated that:

... while New Zealand's race relations were sometimes said by some to be the best in the world they remained only as good as those of us in New Zealand society who were prepared to listen to each other and to work at relationships even when we didn't want to, and that it appeared that the minority groups had to work the hardest. ${ }^{271}$

I commented on the growing political awareness of Maori, the confidence-building networks of the Department of Maori Affairs Tu Tangata programmes, ${ }^{272}$ Maori concerns and their demands for self determination. I mentioned the universals and similarities with NZEI thinking in educational philosophy and practice presented in the Consultation papers.

In summing up the Consultation deliberations, Robert Harris asked, 'education for peace, disarmament and respect for human rights: Who and for whom? What? How?'273 'Who and for whom' involved teachers and the role of parents from preservice to teacher education. 'What' referred to the curriculum. 'How' was about

270 Taylor, K.M. (1982), p. 20.

${ }^{271}$ Ibid.

272 Department of Maori Affairs (1979). Te Kaea Magazine, 1 December, pp. 4-8.

${ }^{273}$ Harris, R. (1981). UNESCO/WCOTP Consultation on Education For Peace and Respect For Human

Rights: Summary of discussions on an inventory and evaluation of experiences. Geneva:

UNESCO/WCOTP. 
methodology inside and outside the classroom, the relationships between teachers and parents, and the different approaches to education in different countries. ${ }^{274}$

After day and night sessions all week, the 60 page draft document in French and English was completed for Consultation approval. UNESCO would have its draft publication with an emphasis on educating the educators. My final comment to the Consultation, in thanking them for their contributions and wishing them well in their endeavours for peace education, focussed on our common hope, expressed in the Maori whakatauki (proverb):

Kia tau te Rangimarie, waiho ki te taha te ngakau pouri.

Cast anger aside and let reason prevail.

IMPRESSIONS FROM THE CONSULTATION

I recall some very touching human responses throughout the Consultation. Never feeling isolated or alone. Being constantly surrounded by warmth, laughter and chatter. Refreshing, sincere, physical contact greetings each morning. Having a spontaneous personal voluntary social interpreter instantly available. Remembering to wear my headphones and make sure that the interpreters had sufficient time for translation as the sessions proceeded. Delightfully assertive men suggesting the gown 'Madame would please wear for the photograph' and sending me off for 'la plume,' my Te Atiawa Iwi Maori Raukura (feathers). Saying my name only once for it to be heard and pronounced correctly, in distinct contrast to the New Zealand scene. Bright colours injected into the proceedings by the Senegalese and Nigerian national dress. The sadness I felt for the female participant travelling alone on a specific route because of her nationality, and being afraid of not being understood. The frustration of another participant, who needed a visa for every country he drove through. The humour and camaraderie we enjoyed, despite cultural and language differences. The excitement and beauty of Mont Blanc, seen through the early morning cloud and again in shadowy grey but clear form one evening. I particularly remember the efforts of participants who commented

274 WCOTP (1981). Echo, XXX (3), September, pp. 4-5. 
favourably in English about the NZEI as I farewelled each one individually from the conference. Most of all I remember the marvellous patience and courtesy with which NZEI was recognised, and to which I was treated from the time I left New Zealand until I stepped off the plane and returned to my home reality.275

After the Consultation I went on a wonderful tour of Europe especially tailored by the Conference Secretariat and the French observer. I remember they were horrified that, speaking only English, I was going to travel on trains for four weeks. I didn't even know that I needed to get to Berne and speak French or German to get my train pass stamped. I was most appreciative of the German student who came to my rescue there.

My reflections on Maori comment recognised that the spirits of my Tupuna, ancestors, went with me, guarded and guided me, and brought me back the stronger for having had international experiences with people I had never met before, from countries I had only read about. I also had a much deeper appreciation of the mana, the intrinsic power, and the high standing of NZEI among teachers across the world, built up over time by many New Zealand teachers of stature. ${ }^{276}$ I was very conscious of the freedoms I enjoyed as a teacher and a New Zealander, compared with some of the other Consultation personnel.

Further reflections show intangibles from that experience that have continued to influence me. I returned to New Zealand justifiably proud of my identities as an NZEI member, Te Atiawa iwi, Maori/Pakeha woman teacher, and a person in my own right. I was comfortable that I had met the expectations of those who had sent me across the world. Arriving back when I did, I missed the activist confrontations against apartheid on New Zealand rugby fields. ${ }^{277}$ Later, when I was on legitimate NZEI business meeting an important international educator, I was followed around

\footnotetext{
275 For a discussion of New Zealand women's involvement in peace activities and links to international peace movements, see Coney, S. (Ed.) (1993). Standing in the Sunshine: A History of New Zealand Women Since They Won the Vote. Auckland: Penguin Books NZ, pp. 320-322.

276 NZEI National Secretary, correspondence with author, 20 August 1981.

277 There were widespread mass protests against the New Zealand rugby team playing the South African team in New Zealand, 1981, because of the apartheid regime in South Africa.
} 
the Auckland Airport terminal being hissed at by an aggressive racist Pakeha male: 'You're a protestor. I know you're a protestor!' I knew I was definitely back home.

Following the Consultation, I was invited to write the chapter on Pre-School Education for the book to be published by UNESCO, which was to be made available to teachers in the UNESCO member countries. ${ }^{278}$ NZEI, especially John McKenzie and Anne Else (then editor of the NZEI Journal), provided a high level of support with the writing, regular communication with WCOTP, getting approval for an extension of the very tight deadline, and the editing of the final draft. Unfortunately, two years later in 1983, at the Regina WCOTP Assembly, I learned that the draft had not been received by the main editing committee in the UK. No one was able to establish why. I had a copy of the draft with me that I was able to leave with Robert Harris. ${ }^{279}$

In 1985, since I was going to be in Calgary, I was invited to 'give the Institute a few days of your holiday', and join the NZEI delegation to the WCOTP Conference in Regina, Canada, ${ }^{280}$ as well as the post-conference seminar in Vancouver. Contacts I made in Regina led to my attending by invitation, subsequent seminars in Banff, and Los Angeles on my way home.

\section{MinisTERIAL APPOINTMENTS}

I was appointed by the Minister of Social Welfare to the Allendale Girls' Home Visiting Committee in 1983. An individual member of this small committee sat with an individual girl to encourage conversation. At that time, 'the government was disestablishing many of the big social welfare institutions and trying to establish community networks for young people'.281 I also assisted staff in writing their submissions on the pending closure of Allendale Girls' Home.

\footnotetext{
278 Harris, R.T., correspondence with author, 24 November 1982. See also Taylor, K. M. and McKenzie, J. L. (1983). 'Teaching About Major Issues Facing The World Today'. Unpublished draft copy, author's collection and NZEI Library.

279 Taylor and McKenzie (1983).

280 WCOTP/CMOPE (1986). Assembly of Delegates Working Papers, Regina, Canada, 1-7 August. 281 Connor (1992), p. 53.
} 
On the nomination of the NZEI National Executive, I was appointed in 1985 to the Auckland Teachers College Council by the Minister of Education. I was involved in a number of Council Committees, including the Women's Advisory Committee, Staff Appointments Committee, Selection Committee for entry to Teacher Training programmes, and the Curriculum and Equity Policy Committee. I recall a racist Pakeha voice saying: 'We all know how you got there, Marie.'

In 1988, the National Women's Advisory Committee on Education was set up to advise the Minister of Education on all matters concerning women and girls in the education system. The Education Gazette of 15 September 1988 called for nominations for its 13 members, and I was appointed. With an Auckland Adviser on Maori Education, Freda Paratene, I became involved in a small research project that resulted in a report, Maori Women and Technology. ${ }^{282}$ The document was presented to the Girls and Women's Section in the Policy Division of the Ministry of Education.

\section{MAORI WOMEn IN MANAGEMENT}

Maori Women in Management grew out of three national in-service courses held in 1987 and 1988 in Wellington. I was not a course member. The purpose was to bring together able Maori women teachers already appointed to, or considering, senior positions. The courses were the first of their kind to specifically target leadership and Maori women teachers by the then Department of Education and newlyappointed Maori Woman Inspector of Primary Schools, Puna McConnell.

\section{COURSE ORGANISATION}

Two Maori women Senior Teachers approached me in 1987 to lead the Auckland regional group. Auckland is not my Maori tribal territory. Despite my having lived and worked in Auckland since 1955, I will always be manuhiri, a visitor from the

282 Paratene, F. M. L. with Taylor, K. M. (1992). Maori Women And Technology, Research Report to Ministry of Education. Wellington: Ministry of Education, p. 1992. This research project is discussed in more detail below. 
lands of Te Atiawa Iwi Maori. Only after extreme pressure, 'because you know everyone and know what to do', did I agree to work on my idea of a collaborative Mana Wahine Maori Feminist organisation of facilitative leadership, with an Auckland-based co-ordinating committee of five. I floated the ideas and they did the work.

In January 1988, during the school holidays, the Co-ordinating Committee offered a fourteen-day residential Department of Education funded in-service Maori language immersion course to Maori women teachers who had attended the national courses, as well as teachers selected from schools in the Auckland province. Two venues, Auckland College of Education's Tutahi Tonu Marae and the seaside residence of a friend at Ruamahunga Bay on the Coromandel Coast, south of Auckland, were available.

We aimed for progress reports and future planning for Maori women teachers in the Auckland region, strengthened by the theoretical perspective of Mana Wahine, Maori Feminism. The January timing was both a therapeutic and a learning opportunity for the women. The Tutahi Tonu venue provided for speakers and workshops. An inspiring spontaneous interactive all-night session on the Rakau, sticks, method of teaching Te Reo Maori language, using cuisenaire rods, was led by an Otago University Maori male lecturer who 'heard about you women and just called in to see everyone'.

A notable first for the course was the group of Pakeha teacher volunteers who worked in the Marae kitchen during our deliberations, and the importance of their contribution to the Marae function. Course members were then free to participate full-time in workshops and discussions, rather than being diverted to mundane matters.

During the second week, high on a hill overlooking Ruamahunga Bay, our residence venue became our marae. We had no kitchen help, as in Auckland. We gathered, cleaned and cooked mataitai, shellfish, and enjoyed bush, views, unpolluted natural spring water and the regular daily exercise of climbing a long steep slope. Breakfast, 
recalled Freda Paratene, was 'oysters fresh off the rocks with a squeeze of lemon washed down with the local beverage cooled in a rock pool'. Lunch and dinner were produced voluntarily by those most comfortable in the kitchen. Cleaning chores were spontaneously shared. Unquestioned acceptance of interactional positioning and re-positioning in role interchange and role reversal is common to gatherings of Maori women. The unspoken process prevailed in an atmosphere of relaxed understanding about where we had come from and where we were going together.

Inspired by her surroundings, one woman wrote and sang a series of songs for young children about bush, sea and sky creatures observed in their environmental habitats. Another penned similar supplementary reading material. Still another recorded an adventure serial story about the goat, tethered on a long chain, who was intended to be a lawn mower for the absent landlords, but who demonstrated a fanatical, highly entertaining attachment to a course member. All texts were later shared and used in classrooms. We wrote, spoke, sang, planned, laughed and shared power.

An important outcome was to plan, organise and facilitate Political Literacy, Course no. 23, for the 'Maori Women in Management' seminar at Walters House/Tamaki Education Centre, Auckland. This was held in two two-day sessions followed by recalls, one to be held in the Bay of Islands, the other in Auckland. The major objective was, 'To offer a support structure for the promotion of Maori women teachers through the educational hierarchy into decision-making power positions'. ${ }^{283}$ Again, Department of Education funding was negotiated from the Primary Teacher In-service budget. Again, we encountered resentment from teachers about our access to funding.

The Auckland committee sourced a wide range of personal and professional networks. The Governor General, Sir Paul Reeves, consented to be Patron. ${ }^{284}$ The NZEI National President released a statement, published in the NZEI Newsletter.

283 Taylor, K. M. with Paratene, F. M. L. (1989). Report Of Maori Women Teachers in Management 'Political Literacy' Course (circulated to committee and course members), p. 4.

284 Official Secretary, Government House, Auckland, correspondence, 9 October 1987 and 22 February 1988. 
The District Senior Inspector of Primary Schools, Auckland, was another firm ally. But we fielded much criticism from male Maori and Pakeha Principals and teachers.

Sixteen teachers from the Auckland region were targeted through networks into two location groups. Data was gathered by questionnaire prior to the course. Information was requested relating to years of service, types of school, qualifications, and individual aspiration goals. An expected preference for face-toface interaction, with an opportunity for questionnaire clarification, was identified. Data collection revealed the necessity for Maori women teachers to strategise for setting achievable goals, plan optional pathways to realise career potential, and develop a positive realistic approach to promotion and academic qualifications. Regular access to peers, role models, and negotiation of sharing dual and triple workloads with Pakeha teachers was essential. Individual success was viewed as strengthening wider personal collectives. ${ }^{285}$ The committee was confident that given support and information, the Maori women involved were politically able to strategise to move themselves forward and influence Maori women teachers and others in their workplaces.

Reflection upon issues arising out of the course showed a lack of promotion and also an isolation of Maori women teachers in the Auckland province. Professional isolation, dual ethnic linkages, communication, dual accountability, teacher overload and management emerged as key components for further discussion. A comfortable mix of Maori and English languages was a natural feature of interaction.

\section{Collaborative Summary}

The course findings showed that the Auckland group of experienced women should continue to encourage, negotiate, initiate, innovate and predict with younger Maori women teachers in an interactive tuakana/teina relationship, as a positive counter to feelings of isolation and lack of political knowledge of the education system. A high priority was maintenance of Maori identity and linkages with other Maori

\footnotetext{
285 See Taylor with Paratene (1989).
} 
women teachers. The collation and dissemination of information to local teacher whanau, and linkages to teaching agencies, organisations and personnel, were also important positive support processes for involvement. ${ }^{286}$

Maori women teachers were equally accountable for their behaviours and performances to two different communities, cultural Maori and professional Pakeha. Coping strategies in both Maori and Pakeha cultures were recognised as a teaching strength not readily available to their Pakeha colleagues. Clear verbalisation and meticulous documentation were essential elements of positive communication and progress. With a working appreciation of protective implications related to the effect of themselves upon others and of others upon themselves, a very useful reflective pathway would result. Within their responsibilities and without exception, Maori women teachers felt overloaded by additional expectations and exploitation to deal with at-risk Maori children across the school, simply because they themselves were Maori. These situations necessitated personal self-rescue and survival strategies, within negotiation processes towards quality and excellence as professionals of dignity. This aspect of management relationships translated into processes with which the women were familiar, those of collaboratively walking the talk together. ${ }^{287}$

Clearly there were implications of powerlessness for the women in a system which they felt was not accepting of their Maori identity. A detailed report of the organisation, the course and recall days was provided to course members, the course committee and the Auckland Primary Schools Inspectorate.

Upon reflection, the women were enabled to move on in their various fields at a pace comfortable to each of them. As a consequence of the course, all won senior positions, some completed academic qualifications, and all generally made changes in their lives that they had not considered possible prior to the course. They were low-key in successfully setting up networks. Active interest in NZEI increased, and one was appointed an NZEI Field Officer. The women made their own employment

\footnotetext{
286 Taylor with Paratene (1989), pp. 21-22.
}

287 Taylor with Paratene (1989), pp. 16-20. 
choices in and out of teaching, and took time out without feelings of guilt when they felt it essential to their physical well-being. More importantly, they became effective in subliminally influencing teachers, children and their workplace communities. As Mahia Wilson noted. 'People keep popping up in one's life. Influences kicked me along. We are influenced by people who do not know they are influencing.' 288 Kaupapa Maori and Mana Wahine theory affirmed the women's view of the world, validating their choices and decisions to proceed in their own ways to achieve confidently in the arena where they were most comfortable. Because they were adaptable and open to change, they felt that they were valued and their gifts and talents were appreciated as worthwhile. New knowledge meant self-empowerment. They developed workable coping and negotiating employment situated strategies across Maori and Pakeha cultures, and initiated personal relationship changes in their workplaces. Mana Wahine enabled the women to demonstrate with dignity that their strength was in their identity as Maori, and they were prepared to build on that strength to provide more readily available collective and professional support networks. The women wanted to be successful as they understood the meaning of success within their Maori woman teacher identity, and felt that such networks were not encouraged in the competitive individualistic approach that was the functional norm required of them in their workplaces.

Sharing their stories in the Kaupapa Maori and Mana Wahine spaces was also a power-sharing venture. This enabled the women to move alongside linkages into a new employment related group, where the degree to which each was Maori was acceptable and appreciated. Their collective relationships, arising out of their being Maori, became the basis for positive change in viewing their employment field, interactional positioning, personal development, and career prospects.

\section{Te Ropu Wahine Maori Toko I Te Ora: MaOri Women's Welfare LEAGUE (MWWL)}

For about thirty years I was a member of the Arahina Branch of the Maori Women's Welfare League (MWWL), which was officially inaugurated in 1951. Historical

288 Taylor with Paratene (1989), p. 34. 
events impacted on Maori during the post-war years. Prime Minister Peter Fraser's vision for Maori, through Labour's welfare state Acts and policies, had by 1950 brought huge gains in housing, health and education. However, rehabilitation of returning soldiers, land settlement and urban migration brought concerns of readjustment from a rural to an urban economy. Family support structures were undermined by issues of location, housing, health, alcohol, class and race. Against a background of paternalistic community policies, the first national Maori organisation, the MWWL, government sponsored and supported, was formed, grounded in support for the welfare state and Maori working class. As Tania Rei, Geraldine McDonald and Ngahuia Te Awekotuku note:

During the first five years, their achievements were extraordinary, considering the massive changes which the Maori population was undergoing and the large-scale disruption brought about by the shift to the towns and cities. ${ }^{289}$

One of the League's first initiatives, instigated by its first President, Dame Whina Cooper, was a survey of Maori Housing in Auckland. The Arahina Branch was active in dialogic encounters, gathering data for the survey through door-knocking and interviews in Freeman's Bay, Central Auckland, in 1953. The result showed at-risk rural Maori urbanised into overcrowded, insanitary, sub-standard accommodation. Local government and state departments were approached at local, regional and national levels to increase the availability of low rental housing for rural families relocating to cities.

Arahina Branch was notable as a source for League Officers: Dominion Presidents and Vice-Presidents, Area Representatives to the Dominion Executive, Regional Chairpersons, a Regional Treasurer and an Annual Conference Steering Committee Chairperson were all drawn, over time, from its ranks. Its multicultural face exemplified Object (8) of the League Constitution, 'To promote understanding between women of all races', ${ }^{290}$ and it drew membership by word of mouth from across greater Auckland. In my time I recall women of Indian, Canadian, Filipina,

\footnotetext{
289 Rei, T., McDonald, G. and Te Awekotuku, N. (1993). Nga Ropu Wahine Maori: Maori Women's Organisations. In Else, A. (Ed.), Women Together, Nga Ropu Wahine o te Motu: A History of Women's Organisations in New Zealand. Wellington: Historical Branch, Department of Internal Affairs and Daphne Brasell Associates, pp. 3-17, p. 10.

290 Maori Women's Welfare League (2002). Constitution. Wellington: MWWL, p.2.
} 
Dutch, Australian, Chinese, Maori Yugoslav, Maori Indian, Maori Pakeha, Maori Chinese, English, and Pakeha New Zealand ethnic groups who were members. Occupations ranged over a wide field, including mothers, academics, medical doctors, teachers, managers, administrators, writers, painters, weavers, as well as a travel consultant, a hypno-therapist/magician, and a union official. New Zealand Department of Maori Affairs Welfare Officers were ex-officio League members. Because of personal life changes, some Arahina Branch members moved on and started new branches in Aotearoa/New Zealand, as well as overseas, in Sydney, Perth and London. ${ }^{291}$

In reflection. through the MWWL National Conference forum, the Arahina Branch women consistently attempted to bring about changes to state policies in areas of, for example, health, housing, and education. Seen through the eyes of Mana Wahine, Arahina Branch, like many other branches, was a powerful influence in challenging the unequal position of Maori vis-à-vis Pakeha. Without exception, each member was a powerful woman and an achiever in her own right. The elements of crosscultural identity, cultural flexibility and readiness to argue reasonably in dialogic encounters strengthened the resilience and endurance of the Arahina Branch in positive cross-cultural interaction.

I was sponsored to become a member of Arahina Branch in 1971. It was also the year when 'the storm over Washday at the Pa erupted' at the League's Dominion Conference. ${ }^{292}$ Ans Westra, who had emigrated from the Netherlands, was a freelance photographer whose work was sometimes published in a magazine produced by the Department of Maori Affairs. Washday at the Pa was a Primary School Bulletin issued by the New Zealand Department of Education. It showed rural Maori children playing inside and outside their 'run-down house' while waiting to shift into a new house. League women took issue with Westra's non-Maori status; they saw some photographs as misleading, culturally inaccurate, and disadvantaging Maori children in comparison to Pakeha, making the children 'a butt of their derision'. Following the League making its case for the withdrawal from

291 Mana Magazine, 59, August-September 2004, pp. 8-10. 292 May (2011), p. 214. 
primary schools of Washday at the $\mathrm{Pa}$, the Minister of Education 'agreed to the withdrawal in the interests of racial harmony'. ${ }^{293}$

Monthly League meetings were held in member's homes, community halls, and schools. From its inception, Arahina Branch carried out many fund-raising projects providing financial and volunteer support for grassroots welfare assistance to families. Overseas branch members requiring medical treatment in Auckland were hosted and supported. Members engaged in hospital concerts, visited, and provided personal comforts and flowers to the sick and bereaved. They sewed children's garments and quilts from donated factory off-cuts, and sorted and distributed surplus clothing from school gala days. For many years, a stalwart Arahina Branch member produced and distributed Korero, a monthly newsletter to keep all members informed of branch activities. ${ }^{294}$

The 1975 National Conference adopted the remit, "That the $6^{\text {th }}$ of February be known as "Waitangi Day" and neither the name nor the holiday celebrating this historic day ever be changed.'295 After being approached, the Auckland City Council approved and planted a striking Maori Women's Welfare League garden, ${ }^{296}$ which bloomed in Albert Park for three months.

\section{A Health Research Project And Involvement As Auckland Area Representative}

A major national research project on the health of Maori women was mooted in 1975. However, it was 1981 before the research was properly underway. The culmination of the project was Rapuora: Health and Maori Women, a valuable indepth study using Maori interviewers. ${ }^{297}$ Arahina Branch made an early decision not to do interviews for it, because some of their members were not Maori, and would be ineligible as interviewers. The report was reviewed in 2001, and progress

\footnotetext{
293 May (2011), p. 216.

294 MWWL Auckland (2002), Tamaki Makaurau Maori Women's Welfare League Regional History (circulated to Branches), pp. 1-16.

295 MWWL Auckland (2002), p.10.

296 See photograph held in author's collection.

297 Murchie, E. (1984). Rapuora: Health and Maori Women. Wellington: MWWL Te Ropu Wahine Maori Toko I Te Ora.
} 
on an expanded Rapuora 2 study, this time including men, was delivered to the National Conference in New Plymouth.

I represented the Auckland Regional Council of the League in 1975 at the national conference in Wellington on 'Education and the Equality of the Sexes', where I was able to move spontaneously in and out of my Maori/Pakeha and teacher identities. I was also in the support group for Mira Szaszy at the 1975 United Women's Convention in Auckland, when she delivered a key paper focused on seeking equity for Maori women with Pakeha women.

From 1976 to 1978, I was the elected Auckland Area Representative to the MWWL Dominion Executive for the district extending from Mercer, south of Auckland, to Warkworth in the north. With Maori Welfare Officers, we revived branches in recess, such as Manurewa, and established a Junior Branch at the Anglican Queen Victoria Secondary Boarding School for Girls in Auckland.

Through the League, I was invited in 1979 to be involved in the Women's National Tu Tangata Wananga, held in Wellington under the auspices of the New Zealand Department of Maori Affairs. A networking arrangement was proposed by the women attending. A planned approach was then requested for the holding of regional Tu Tangata Wananga. ${ }^{298}$ This was later carried out very successfully. The women were encouraged to look critically inwards at themselves, 'take hold of "Maori power" and turn it upon both the problem areas as well as the economic growth needs'299 related to current issues facing all Maori. In other words, the women were being asked to draw on the strength of their whakapapa, genealogy, resilience and endurance.

In 1984 the Governor-General, Sir Paul Reeves, and Lady Reeves invited the League 'to spend time at Government House, Auckland'. An Arahina Branch member, Wiki Henskes, led the organising committee for the very successful Garden Party held at

\footnotetext{
298 Secretary for Maori Affairs, correspondence, 26 January 1979.

299 Puketapu, K. (1982). Reform from Within. Wellington: Department of Maori Affairs, p. 2.
} 
Government House, where 'Afternoon Tea was served on the lawn and the waiata and action songs performed by each region made for a memorable day.' 300

Finance was always a real problem. Responsibility lay with the region's branches, whose community resources were already over-stretched to provide travel funding for their National Executive Area Representative. Te Atatu and Arahina branches rallied to supplement a small grant from the National Executive to provide travel funding for my attendance at Executive meetings in Wellington. The balance, for travel around Auckland branches, I met myself and used my own car. From 1977 to 1978, I was elected Auckland Regional Council Chairperson, and was President of Arahina Branch until 1998.

Arahina Branch became involved in the Auckland Region Immunisation Programme in 1992. Family data was gathered and mothers informed of the need for protective immunisation of children, aged up to two years, against 'nine serious diseases and, to be fully protected, the need to have all the immunisations in the schedule'. The branch also participated in the region's Whanau Toko I Te Ora Programme, focussed on 'children's wellbeing, on improving the skills and confidence of parents, and on providing basic support to whanau who are struggling'. 301

Over the years, aging and ill-health combined to limit much of the activity of Arahina Branch members, until a few active young mothers became members and continued community support through delivery of state health contracts.

\section{MaORI Women's Welfare League Golden JUbILEE}

The League held its Golden Jubilee Conference in 2001 at New Plymouth. I was the second speaker on a sixteen member panel. Central to my address were theoretical underpinnings that have now become part of my thinking. I drew upon western categories of liberal, radical, socialist and postmodern feminism, ${ }^{302}$ adding a Maori Mana Wahine overlay to explain the notion of feminism in the context of the vision.

\footnotetext{
${ }^{300}$ MWWL Auckland (2002), p. 9.

301 MWWL Auckland (2002), pp. 13-14.

302 See Tong, R. P. (1998). Feminist Thought. Boulder, CO: Westview Press.
} 
Another aspect of the context of the address was to do with my own positioning. Here, Sidonie Smith's metaphor of an identity body was useful, ${ }^{303}$ as the autobiographical skins of Maori/Pakeha/woman/teacher interacted in shifts of identities at social, gender, ethnic and political interfaces. In this case, Te Atiawa Iwi Maori collective identity located me centrally in legitimated values, languages of ritual, performance and communication, within the organisation and the material circumstances of the conference environment.

In terms of envisioning, Linda Tuhiwai Smith states:

One of the strategies that indigenous peoples have employed effectively to bind people together politically is a strategy which asks that people imagine a future, that they rise above present day situations which are generally depressing, dream a new dream and see a new vision. ${ }^{304}$

The vision I spoke of was an autonomous, vibrant, inclusive, global Maori Women's Welfare League moving from a sound research base for positive change. Women themselves, or their children, identifying as Maori, could make independent informed choices about how, when, where and in what form they would live their lives with dignity. These were women who would continue to develop the natural talents of themselves and their families, and participate in expanding the pool of creativity, diversity and credentials that reflects contemporary Maoridom. It was about the aspirations of Maori women who knew no bounds in asserting their right to be what they chose, in the scenario of knowledge, gender, class and race. It was about strengthening the woman who strengthens the family and other collectives of her choice.

In my reflections, I realised that my association with the League provided me entry to local government, high profile public figures, and international indigenous peoples. The experience was widely diverse. My greatest critics, always my own people, often couched comment in fun and laughter, but sending serious messages that caused me to reflect in depth upon my actions. Cultural flexibility and wide

303 Smith, Sidonie (1993). Subjectivity, Identity and the Body: Women's Autobiographical Practices in the Twentieth Century. Bloomington, IN: Indiana University Press.

304 Smith, L. T. (2012), p. 152. 
ranging dialogic encounters provided numerous learning opportunities, some comfortable, some uncomfortable, to interact as and with Maori, Maori/Pakeha or Pakeha to build my resilience and endurance. The League enabled me to work with and as Maori, underpinned by Mana Wahine Maori feminism and Kaupapa Maori theory, at the same time as I engaged in my professional teacher and NZEI roles. My Whakapapa of Maori identity was acknowledged. I have only the greatest respect for the League women who continue their work with Maori at their flax roots levels, to make a difference with families across the country.

Roberta Sykes presents profiles of Australian Aboriginal high achieving women with whom Maori Women project similarities. The women of the Arahina Branch may find themselves in similar positions:

... all born in Australia, of rich heritage and tradition. Their lives are neither uniformly bleak nor blissful. These life stories are full of pain and joy, work, families, children, love and solitude. There is a connectedness between some of them but not all of them and many were inspirations, support or role models for others. The traditional women particularly, are extremely modest and reticent about making much of their personal achievement. This approach is encouraged and highly valued in traditional society. As well none of the women directly addressed the hardships they incurred in raising their families, other than, mainly by allusion, the financial difficulties....As well as differences between them they share many things in common, the most obvious of which is their indigenousness. They are Australia...They lay prior claim to the title of 'Australian women' and feel no need to qualify themselves further. ${ }^{305}$

Traditionally, neither Maori nor Aboriginal women can be anonymous, because the extended family concept of both cultures makes all things public. Both cultures practise a form of character evaluation according status within the group. Neither conforms only to the dominant view of achievement and success.

305 Sykes, R. (1993). Murawina, Australian Women of High Achievement. Lane Cove, NSW: Doubleday, pp. 4-5. 


\section{Concluding Comments}

Reflections upon my training and employment years drew upon my appreciation of the great years of 1950 and 1951 at Christchurch Teachers' Training College. Conscientisation as a teacher, begun during my own schooling, broadened and deepened through interaction and Maori/Pakeha dialogic encounters in schools. As a student teacher trainee, I developed a more specific awareness of the theoretical nature of the teaching task and an understanding of the purpose of schools for the reproduction of dominant Pakeha Western culture. Schools were mechanisms for social control, social order, assimilation and integration of Maori. I carried out those same concepts as a diligent practising teacher and agent of the state in paid employment, whilst maintaining my own identity as Maori/Pakeha. Maori were highly visible in Maori Primary Schools where, apart from teachers and their children, Pakeha were mainly in the minority, but held the positions of power and authority. Maori were either invisible or visible as behaviourally different, often the troublesome misunderstood minority in the general primary mainstream schools to which I was appointed.

Politicisation required that I should understand the dominant culture, its social mores, systems, beliefs, values, and individual aspirations, transferred from school communities into classrooms and vice versa. The idea of equality of educational opportunity for all was a socio-political seed that often struggled to flourish through the constraints of government policies, racism, sexism, class and teacher expectation in my workplaces. I was, in many respects, a marginalised Maori/Pakeha woman teacher, strengthened by my whakapapa, early years of family nurture, and the assimilation policies of Pakeha schooling. In order to survive, I deliberately passed into being Pakeha. When I moved to Auckland schools to avoid the constant grating mispronunciation of 'Kura' (Koorah), whilst fulfilling the requirements of paid employment, I used my Pakeha name, 'Marie' which listening-impaired Pakeha, focussed on my brownness, pronounced as 'Maria'. I operated in my little world in a dichotomy of compliance and resistance. Membership of NZEI provided the professional organisational arena of my 
employment politicisation, in terms of wide ranging conditions of service and teaching practice.

Ritualisation as a social characteristic of the times featured in the 'game playing' of the system as an important political component. Through employment related bodies I developed portable rituals of language and engagement from the multilayered world of teaching, transferable to the complexities of wider diverse communities and committees. 'Playing the games' for promotion became second nature as I moved from one selected school to another.

It was only after the review of Educational Administration and the release of Personal Files by the Department of Education that I realised the concessions that had been negotiated on my behalf. My whakapapa, geneaology, my family, my early mentors, many teachers and those concessions were the most powerful elements influencing my own directions as a Maori/Pakeha woman teacher.

I often reflect upon my teaching career, surrounded by tangible reminders. I retired in the personal belief that I had served well all the schools to which I had been appointed, the children I had been privileged to teach, their parents, the communities in which I had lived, the teachers alongside whom I had taught and the friends I had made. I had enjoyed a multitude of varied Maori/Pakeha dialogic encounters, honing life skills that were to serve me well after teaching. Through both positive and negative culturally flexible experiences and numerous speaking engagements through NZEI, schools, and community organisations, I had grown enormously. I knew that I had the resilience and endurance for a long fruitful retirement. It had been such fun along the way! 


\section{CHAPTER FIVE}

\section{RETIREMENT FROM TEACHING AND ENTERING MY THIRD AGE}

$$
1991-2017
$$

\section{INTRODUCTION}

Chapter Five, 1991 to 2017, describes the 'playtime' of my present third age. In this section I focus on my association with teacher education, my work on the New Zealand Teacher Registration Board, my juggling of university study, and becoming Trustee/Chairperson of Ngahina Trust, our Family Land Trust. I 'play' within the freedoms of aging, good health restored by surgery, life interest choices, property ownership and financial security.

\section{The New Zealand Teacher Registration Board (TRB)}

I had the honour and privilege of a seven-year term with the New Zealand Teacher Registration Board, from 1989 to 1996 . The Board was a crown agency, created on 1 October 1989 during the restructuring of the New Zealand education system. I was nominated by NZEI, and after rigorous screening by the Ministry of Education, I was appointed by the Minister to a position as a full teacher member of the fivemember Board.

The historical scenario of teacher registration is discussed by Peter Barlow as one of 'evolution', 'devolution' and 'revolution'. 306 Practising teachers in state primary schools were the first group required to register on the Register of Teachers. Later

\footnotetext{
306 Barlow, P. (1996). 'Teacher Licensing: Compulsory or Voluntary.' Paper prepared for the International Bureau of Education 45 ${ }^{\text {th }}$ International Conference on Education, 'Strengthening the Role of Teachers in a Changing World', Geneva, Switzerland, 30 September-5 October. See also Alcorn, N. (2015). Between the Profession and the State: A History of the New Zealand Teachers Council. Wellington: NZCER Press. The TRB became the Teachers' Council in 2002. In 2015 it was replaced by the Education Council of Aotearoa New Zealand.
} 
regulations included teachers from other sectors in education. Section 131 of the Education Act 1964 gave clear direction on the requirement for registration of anyone seeking appointment as a teacher.

The new Board was responsible for the maintenance of the register; registration procedures, according to statutory criteria; and the approval of registration as full, provisional, or subject to confirmation. De-registration procedures and decisions were followed by notification to school governance bodies of names of de-registered teachers. At its first meeting, the Board had immediate access to legal opinion and expertise that was of great assistance in the interpretation and implications of the Education Act related to Teacher Registration.

A Director was appointed, suitable serviced premises leased and an administration staff installed to begin compulsory registration of teachers in the general state education system. By early 1991, the tremendous task of creating a new register of approximately 50,000 teachers had been accomplished. A system of notification to schools of de-registered teachers was also in place.

During my term on the Board, radical, far-reaching administration reforms were introduced, decentralising state control of education to crown entities, selfgoverning schools and community partnerships. The aim was to have communities becoming more involved in the governance of their schools.

In reflection, those seven years spent with the Teacher Registration Board were invaluable in terms of honing skills for interpreting legislation, writing official documents, clarifying Pakeha language meanings and attention to fine detail. It was because of this experience that I felt able to participate in 2001 in submission writing on behalf of Ngahina Trust. 


\section{RETURN TO UNIVERSITY STUDY}

The journey as a scholar is important. Compared with Pakeha, there are few Maori women with doctorates and even fewer who pursue them in their seventies and eighties.

My earlier undergraduate study began in 1978, when I completed the New Start Course at the University of Auckland, followed by extramural enrolment in 1979 at Massey University in Palmerston North. The resulting Bachelor of Education brought maximum salary benefit while I was still in paid employment, and was taken into consideration for calculation of my retirement superannuation income. Encouraged by academic friends, I began another period of study in 1992. In 1994 aged 61, I graduated from the University of Auckland with a Masters degree in Education. I had time to stand back and take into account the width and depth of the banks of knowledge held in my memory, with retention and retrieval systems. In terms of my identities, I repositioned myself from education middle-management to student status. This positioning demonstrated to me the wide social and knowledge divides between my life and the lives of many of the other students. I was also very much aware that their need to study was for employment related qualifications, whereas I was there for the sheer pleasure of continuing my academic learning.

In August 2000, I enrolled as a Doctoral candidate at Victoria University of Wellington.

\section{Three Small Research Projects}

In 1991, with much help from my supervisors at the University of Auckland, I completed my Research Affiliate Report, 'Kei Hea Nga Wahine Rangatira'.307 My research sought answers to three questions: Why are there no Maori women

307 Taylor, K. M. (1991). 'Kei Hea Nga Wahine Rangatira'. Unpublished Research Affiliate Report to the University of Auckland. 
principals in Auckland primary schools? Why are there so few Maori women teachers in positions of responsibility in Auckland primary schools? Why do Maori women teachers persistently reflect a low profile in Auckland primary schools?

I sought to locate a sample of third-year Maori Women Division A teacher trainees at Auckland College of Education from 1981-1985, but this proved difficult. Eventually, through Maori networks and conversations, a small group was found. The results of written questionnaire data gathering indicated a number of factors . There were many fewer Maori women teacher trainees than Pakeha. The sample reflected low Mana Wahine self image, cultural isolation in gaining credentials, and professional stultification because of advice to delay credentialing. There was also a paucity of Maori women Senior Teacher role models. A focus on the teacher nurturance role limited upward mobility career prospects. The sample showed a level of political and management illiteracy related to professional accountability as teachers to their school communities, to their Maori communities, and to themselves as Maori women teachers. They had their own people-centred collective view of success, versus individual professional status. There was also a dearth of professional Mana Wahine support groups, as well as problems of recruitment and retention.

In 1992 Freda Paratene, Advisor in Maori and Pacific Island Education, and I carried out a qualitative investigation that attempted to respond to the question: Maori use technology for immediate needs - is this enough ${ }^{308}$

Data for analysis was gathered through a tape recorded, structured, oral, Maorifriendly, group interview process. A pilot sample of five was followed by a major sample of 25 Maori women teachers, trained at Auckland College of Education from 1981-1991, who were teaching in the Auckland and North Auckland areas.

Data analysis showed that technology was seen as a process. There was a particular expectation to access Western technological thought to add to Maori scientific

308 Paratene and Taylor (1992a). 
thought, in the production of bicultural Maori/Western technology. Time-lined recommendations were made to the Ministry of Education.

In 1992 I was contacted by the Principal of Cornwall Park School, Peter Ellery, and invited to conduct a research study of twelve Cornwall Park School families who identified through iwi, to provide the basis for the establishment of a Maori/English bilingual unit. The main research question focused on: Maori language at Cornwall Park School - why and what? 309

Data was gathered through loosely structured conversations that allowed families to discuss their aspirations, expectations and commitment to Te Reo me ona Tikanga Maori, Maori language, customs and beliefs. Research findings indicated that consultation processes and networking would be strengthened by continuing development towards a distinctive option that could be offered to all interested Cornwall Park School parents and children. Once started, there should be minimal interruption to the programme, and professional development should be available to combat the stress and isolation factors directly attributable to carrying out the programme. Entrepreneurial opportunities should also be explored for future adult interest programmes.

The school set up a bilingual unit and appointed a teacher with reponsibilities for a Maori programme. The ceremonial opening of the unit was supported by the Rongomai School Culture Group from Otara.

\section{The NGAHINA TRUST}

The strength of Ngahina Trust lies within whakapapa, genealogy, that began in the Maori Cosmology, descending to, more recently, Ihakara te Ngarara, and continuing down through his sons Epiha, Teira (my father's great-grandfather), and Te Wharemaru. From Ihakara Te Ngarara's lineage through his son Teira, our father and his cousins inherited five blocks of Maori land at Paraparaumu, on the Kapiti

309 Taylor, K. M. (1992). Te Reo Me Ona Tikanga Maori mo te Kura o Maungakiekie, Report to the Board of Trustees and Principal, Cornwall Park District School, Auckland. 
Coast of New Zealand, his home where he grew up, and in Waitara, where his biological parents, to whom he returned as a young man, were domiciled. After discussion between the present owners and their legal advisers, the Ngahina Trust was named to honour the late Ngahina Metapere Teira Taiaki, our father's sister ,who was a Beneficial Owner. She had most recently spearheaded retention of the land, Te Taonga Tuku Iho. Implicit in that naming was recognition of the Tupuna, ancestors, as well as owners of the same generation as Ngahina Metapere Teira Taiaki, who had supported her in land retention endeavours.

Coastlands ShoppingTown was seeking land for expansion. In 1969 it initiated negotiations for access to the Ngarara West B, Ngahina Trust land. The Borough Council was seeking land for roads and a future Town Centre. Legal Advisers of Coastlands, the Borough Council and the Maori owners of the land entered into consultation. It was agreed that application be made by the Maori Beneficial Owners to the Maori Land Court to form a Trust under the Maori Affairs Act 1953. A pre-requisite was the amalgamation of five blocks of land, of which six of the owners were women. At a hearing of the Maori Land Court in Levin on 11 August 1981, the Ngahina Trust, Paraparaumu was constituted. The Trust was established with the Ngarara West B ancestral Maori freehold land's eight consenting related owners from the Teira, Love and Rangikauwhata families, descendants of Ihakara Te Ngarara and two of his sons, Epiha and Teira, underpinned by the sustaining ethos of Te Atiawa Iwi Maori. The reality of the Trust Tupuna dreams for their descendants began to emerge.

The Court also appointed a Solicitor and a Chartered Accountant as Trustees. Both were Pakeha. Judge Durie declared an adjournment, and instructed the Beneficial Owners to discuss the appointment of Advisory Trustees. I was then an active feminist, and noted that there were no women offering themselves. I told my family that with a majority of women owners, the new Trust should have at least one woman Trustee. With my political background in the NZEI, I was very well-qualified and prepared to be that woman. Our late father had been the only male Teira family owner in his generation. He had been raised on the land and regularly attended family meetings about the land. I believed we had a duty to the land and deserved 
representation at the Trustee level. With five- to seven year-olds being my teaching area, I also knew how to use English to ensure understanding by a listener. I had not been considered or approached, but I told my family I would offer myself to the Court for appointment as an Advisory Trustee when the Court reconvened. I expected them to support me, and they did. I and three Maori male owners were appointed by Judge Durie as Advisory Trustees, with responsibility for liaison between the Beneficial Owners and Trustees. The first Annual and General Meeting of the Beneficial Owners was held on 14 May 1983 in the Kapiti Borough Council Chambers.

\section{LAND DEVELOPMENT}

The Ngahina Trust owners knew that they had no expertise to develop the land themselves, nor to access the large amounts of money required for development of Te Taonga Tuku Iho. Consultation with Beneficial Owners showed that they wanted an equal partnership and equal representation on the Board of Directors, with the Alpha Group of Pakeha partners. The Chairman was to be appointed by the Pakeha Partners. After further consultation, a new company, Ngahina Developments Limited, was incorporated on 19 December 1984 to develop the land. The first meeting of the Ngahina Developments Board of six Directors, three from each group, was held on 23 February 1985, and Bruce Mansell was confirmed company Chairman. ${ }^{310}$

On one occasion only, it was suggested that part of the land be sold to provide cash for development. The Maori owners were adamant that the Trust wished to retain all of this particular land for future generations. The Alpha Directors understood the benefits of such land retention, and 'agreed that no land would ever be sold'. ${ }^{311}$ Through regular meetings, misgivings about compatibility and cultural differences were proven groundless. Ngahina Trust and the Alpha Group Directors

\footnotetext{
310 The Board of Ngahina Developments Limited, Paraparaumu, was comprised of two groups: Kura Marie Taylor, Paul W. W. Brunton, Maikara Tapuke, Trustees and Ngahina Trust Directors, with Te Akerama Manuka Taiaki as Kaumatua Ngahina Trust Elder; and Bruce Mansell, Chairman, Richard Mansell, and Barry Clevely, Alpha Corporation Directors. Mansell, B., for Ngahina Trust (2007). Ngahina Trust: A Celebration 2007. New Plymouth: TNL \& Graphics.. 311 Mansell (2007), p. 20.
} 
demonstrated many similarities: both groups were 'family' oriented; both were inclusive of family clusters, grouping together as one 'extended family'; both were keen on growing a sustainable, long-lasting business bringing major benefits to future generations; and both were respectful towards each other. 'The relationship prospered ... through a shared sense of fair play, mutual respect and trust and business always done in good humour.' 312

In 1984, on the recommendation of the Trust Beneficial Owners, I was appointed a Principal Trustee by the Maori Land Court, alongside the Accountant and Solicitor. The business partnership entered into between Ngahina Trust and Coastlands has been successfully maintained, reflecting the spirit intended by our Tupuna when signing the Treaty of Waitangi. I was also appointed Ngahina Trust Chairperson in 1994, I assume because of my teaching background and involvement in teacher politics with the NZEI.

In 2007 Ngahina Trust celebrated 25 years of successful operation, in solid partnership with Coastlands and the Alpha Corporation. This unique partnership is underpinned by the culturally sensitive relationships of both parties towards each other, in nuances of Te Reo Maori and English languages.

\section{LAND OFFERED BACK}

Ngahina Trust had long wanted the return of ancestral land which had been taken by government under the Public Works Act for a public purpose, but was not being developed by the Kapiti District Council. Redress was sought from 10 to 13 May 2010, through the High Court in Wellington, to have 5.11 hectares of land offered back. Our case was meticulously documented with our Legal Advisors. We were very fortunate in the calibre of our negotiator, Bruce Mansell. ${ }^{313}$ Judgement was in favour of Ngahina Trust. With due ceremony, we purchased the land offered back

\footnotetext{
312 Ibid.

313 Sadly, Bruce Mansell died on 15 January 2013. Blundell, K. (2013), 'Coastlands owner remembered as a giant', Dominion Post, 11 February.
} 
in 2013. It is on part of that block of land that the Trust is currently engaged in commercial development, through Ngahina Developments Limited and the Alpha Corporation.

My reflections at the time of the purchase noted its huge significance for the Trust. The return of the land recognised the spiritual, cultural and Tupuna connections of the many generations of Ngahina Trust families who were, and are still, woven into the fabric of the Paraparaumu community.

PARTNERSHIP MAINTENANCE

The partnership between Ngahina Trust and Coastlands has been maintained through transparent ethical practices. There have been very few changes in Trust office-holders, from the beginning to the present day. The Trust is now being managed entirely by its elected credentialed owners, recommended to the Maori Land Court for appointment.

In reflection, I am privileged and proud to have been able to contribute to the growth of Ngahina Trust. As a Maori/Pakeha woman teacher, I draw upon my knowledge of Pakeha organisation and committee relationships, office holding, meeting procedure, strategic planning, goal setting and recording of minutes. I learned a wide range of skills over time through the involvement with the NZEI and the TRB. That sound learning was enormously valuable in the establishment, practices and ethical procedures of the Trust, whilst successfully working closely with Ngahina Trust Beneficial Owners, Accountants and Legal Advisers to develop essential processes and enduring relationships with our Pakeha partners.

Further reflection showed that the NZEI's expectations and example have enabled me to give back in reciprocity to my Maori community and families. I am fortunate to have learned much in the process. I believe that the increase of university graduates in the next generation of Trust whanau bodes well for the future of Ngahina Trust. 


\section{CONCLUDing COMMENT}

There have been many differences between Ngahina Trust's Maori and Pakeha meeting approaches. Humour, clear procedures, consistency in operation and Maori/Pakeha blending are basic to negotiating those differences. The Trust has ethically protected, retained and grown its land base, in accordance with the expectations and identities of the Beneficial Owners. The outcome of reasoned negotiation and application of sound business practices has been of considerable benefit not only to the Ngahina Trust, but also to the Trust's Pakeha partners the Alpha Corporation, the wider Paraparaumu Community, and the travelling public. 


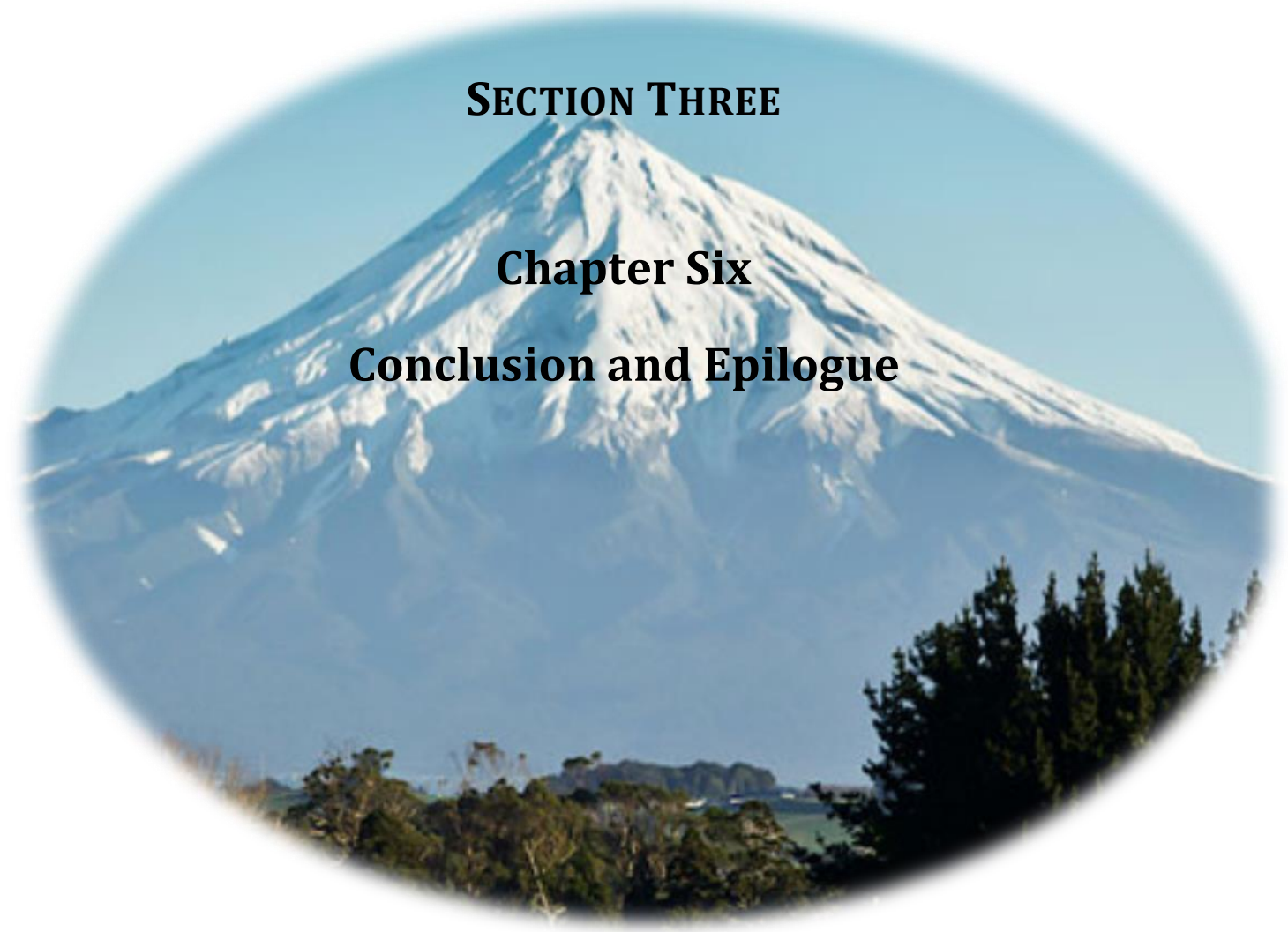




\section{CHAPTER SIX}

\section{CONCLUSION AND EPILOGUE}

\section{CONCLUSION}

This part of the thesis, Kura Marie Teira Taylor: Te Atiawa Paake: Reflections on the Playgrounds of Life, returns firstly to the original intent of the thesis, location of myself as a Maori/Pakeha Paake woman teacher. I offer insights into how I have been centralised as Maori/Pakeha in relationships and dialogic learning encounters, through cultural navigation and spontaneous cultural flexibility with, and alongside, Pakeha and Maori. I have focused, reflected upon and analysed my childhood and family, growing up, schooling, teaching experiences and third age activities. I have had so much fun and enjoyment.

For forty years I was an assimilated, integrated, Maori/Pakeha woman teacher employed in the New Zealand Primary Schools Service as an agent of the state, with responsibility to deliver education policies aimed at the assimilation and integration of Maori into brown Pakeha. After retirement from classroom teaching, I was invited to take up an appointment as a relieving administrator/lecturer involved in delivering the Kaiarahi I te Reo Maori Teacher Training Programme at Auckland College of Education, Te Puna Wananga, Department of Maori. During that time I also successfully mentored one Pakeha and two Maori women individually through their Master's theses.

I continue to be privileged in carrying out the roles and responsibilities of Trustee/Chairperson with the Ngahina Trust. Being a Director of Ngahina Developments Limited, operating in a unique, successful, Maori/Pakeha business partnership of land development and commercial leasing on the Kapiti Coast near Wellington, is another privilege. 
This thesis argues that autobiography is a well-suited research method through which to explore and interpret my life as a Maori/Pakeha Paake woman teacher, and the impact of social history, extending over eighty years. Also argued is that autobiographical narrative has the capability to present my life story from my perspective, my interpretation and my self-representation, rather than from interpretation by others. My autobiographical narrative is also my response to the requests of my late Maori women elders and my teacher friends who, over the years, have often said, 'You should write a book.' This thesis represents that book at this point in time.

\section{AUTOBIOGRAPHY AND WHAKAPAPA}

I believe autobiography is also an appropriate method to research the narratives of Maori/Pakeha men - indeed, any who claim Maori/Pakeha descent through whakapapa, genealogy. I reiterate, my whakapapa links my descent from the cosmology to the present down patrilineal and matrilineal recitation lineages, embracing herstorical and historical lives and social events.

On formal occasions, male whakapapa, genealogical recitation, is the distinctive characteristic identifying and delineating Maori tribal and ancestral land connections, marked, for example, by specific mountains, rivers, lakes, beaches and land boundaries. One person from each generation is usually designated to carry on the recitations of family whakapapa, genealogy. That selected person, in their time, has the responsibility of passing down those recitations and obligations to a selected suitable successor. Language and dialects composed in poems, stories, songs, music, dreams, aspirations, involvements and achievements create historical markers along the whakapapa, genealogically linking people from the past to the present, their tribal lands and particular events. Whakapapa, genealogy constructs my identity and establishes my land inheritances, who I am, what I have become and to whom my past connects me, on into my present and my future. This 
autobiographical narrative method of recording selected events of my life unites my oral whakapapa, genealogical dimension with the written genre about who and what I am. Other Indigenous peoples may choose also to be enabled through similar narrative to present their lives when reclaiming their histories, their identities and their self-representation.

Unfortunately some whakapapa, genealogical linkages may have become tenuous or even invisible, perhaps through colonisation, urbanisation, schooling, Pakeha adoption, or globalisation, as well as the sheer effort of keeping up with modern living. Fortunately this technological age broadens the avenues for researching whakapapa, genealogy, on-line or through personal research, through records of the Maori Land Courts - for example, following the death of a Beneficial Owner, whose proven whakapapa, genealogical descendants, through due process of the Maori Land Court, become beneficiaries of the Ngahina Trust. They then have opportunities to share information about their links into the Trust whakapapa, genealogy, and to hear ours. Avenues of whakapapa, genealogical knowledge, may also come from information related to Treaty of Waitangi Settlements; various Maori Trusts; or a range of people themselves, in conversation at Marae and community gatherings.

I reiterate that while I am not the keeper of our family whakapapa, genealogy, I explained my extended family connections along maternal and paternal lines of descent in Chapter One. I identify and behave as Maori/Pakeha in accordance with my whakapapa, genealogy. I explain family whakapapa, genealogy, connections to my grandsons.

\section{MAIN THEMES}

Three main themes: whakapapa, family, identity; cultural flexibility and cultural navigation; resilience and endurance, recur throughout this thesis. I reiterate, first whakapapa, genealogy, establishes my identity. Secondly, cultural flexibility is spontaneously demonstrated as I navigate my Maori/Pakeha way across, around or over negotiation spaces. The extent of Maori or Pakeha cultures and Maori language 
is also a spontaneous defining element of each dialogic encounter. Thirdly, Maori spaces, Pakeha spaces, Maori/Pakeha and many other cultural spaces I have navigated, honing my social skills resilience and endurance. Those spaces have many multi-faceted and multi-layered stories yet to be told, perhaps in other times and other spaces and for other reasons.

\section{SuB-THEMES}

As the writing progressed, additional sub-themes also emerged. The sub-theme of 'home' as a geographical landscape, dominated by the mountain named Taranaki; and a physical 'home' scarred by the 1860 PekaPeka Block land wars. Waitara and our house where we lived then, sited on the ancestral land where we grew up, providing further deep rooted ties to our home. The powerful sub-theme of 'our mother', a loving, reliable human being in her own right, who loved us, cared for us and was proud of us. She filled our lives with laughter and fun, administered discipline when necessary, was always there for us and taught us much of what I know that has shaped my behaviours and who I am. The sub-theme of domestication, about life skills in practice and the acceptable social norms defining women at that time, many of which I adapted into my adult practices. The subtheme of conservation and economising, ensuring sustainability of resources. The sub-theme of building relationships, based in whanaungatanga of immediate or extended family, and manaakitanga as the supportive caring element. The subtheme of education and qualifications, as the gateway to access Maori/Pakeha opportunities for personal and financial independence. All these provide information through the tapestry of my life experiences.

\section{THEORETICAL UNDERPINNING}

The theoretical underpinning of this thesis is discussed in Chapter Two. The broad Kaupapa Maori theory links Mana Wahine Maori Feminism theory and Aitanga theory, espoused by Linda T. Smith, Kuni Jenkins, Leonie Pihama, Helene Connor, Graham H. Smith and other Maori scholars. Based in Maori knowledge, I believe these theories have formed the most suitable theoretical structure for the narration 
of my selected life events and my identity construction. Embedded in Matauranga Maori, Maori knowledge, the theories are affirming in uplifting and in recognising the position and status of Maori women in the modern world, while in my case, not denying but including my matrilineal Pakeha component.

Despite my lack of fluency in Te Reo Maori, Maori language, I believe that the theories linked to Kaupapa Maori and Maori Feminism have served my narrative well. From my perspective, the narration of my life from birth to childhood to adulthood and into my third age as a Maori/Pakeha Paake woman teacher shows that in some ways, I have been more advantaged than disadvantaged by my English language monoligualism. I recall the occasion of the return of Taranaki by the Crown to the iwi, tribe, when my elders instructed me to be Kaikaranga to return the call from the marae to the visitors, allowing them to proceed. On the same day, they also told me I did not have to learn to speak Te Reo Maori, because there were many others to do that. English was what my mother wanted as my language. I was good at it and I was to speak it for them.

Beginning in Chapter Three with my birth, my narrative moves on through my childhood and schooling. Events encapsulated my social, emotional, physical and mental growth and development as a biddable child during most of those years, with few challenges to authority. I learned to conform to social mores of both Maori and Pakeha cultures, under the guidance of my parents and through schooling, whilst noting early instances of social injustice, and more particularly in later years, in relation to our Ngahina Trust Maori/Pakeha land development partnership.

Chapter Four reveals my ability to apply prior knowledge in social, emotional, cultural, learning and teaching situations, not only to consult and make sound decisions, but to own the decisions I made, and the consequences, as well. I was also very fortunate in having strong teacher mentors and well-trained young teachers on my staffs in the schools to which I was appointed. As I supported them, so they supported me. The political arena of the NZEI and the offices I held brought a balance to my teaching and my political activities as a Maori/Pakeha Te Atiawa Paake woman teacher. 
I believe my parents and my extended family did me an enormous service in preparing me to be independent, to live with my decisions, good or bad, and to treat others as I would wish others to treat me.

\section{EPILOGUE}

As I sit comfortably and ponder upon my life, at the age of 85 , I am mindful that I have always considered myself an ordinary person formed from an ordinary dual Maori/Pakeha cultural background. In writing this thesis, I have come to realise that in many respects, I have also been privileged.

I have experienced the power of privilege as ascribed power that has come with early promotion and positions of status in my workplaces and in my communities. Power has been conferred on me from the time I was a prefect at New Plymouth Girls' High School. I have held power as a Maori/Pakeha teacher in senior positions from 1955 until retirement in 1990, and when holding a range of offices in education and community committees.

It is such power, embodied in experience as a decision-maker, that has enabled me to access the power of financial independence sufficient for my needs, and therefore the power to constructively control my own destiny. As Kay Douglas and Kim McGregor note, 'Privilege is primarily associated with having high social status, professional knowledge and wealth, being ... able-bodied and healthy. The power gained through having privilege can be used in constructive respectful ways.'314 I was greatly influenced by our parents from 1932 to $1949 . \quad$ Their lives were devoted to nurturing us through the halcyon days of childhood, within clear social and relationship boundaries, in the best ways they knew. As stated, our mother was devoted to our wellbeing. We were, of course, exposed more to our loving unpaid homemaker mother, working in conditions of physical drudgery and domestication similar to those of many women of that time. I reiterate, our mother did not experience paid employment herself, nor did she have money of her own. She

\footnotetext{
314 Douglas and McGregor (2000), p.67.
} 
voluntarily left school at Standard Two level. As an adult, her dependence upon our father until she received the government pension in her later years did not detract from her determination to be the best mother she could be to us.

I repeat, our mother as our first teacher, taught us well. Her teachings were about health, hygiene, conserving resources, understanding kaitiakitanga, whanaungatanga, and manaakitanga, Maori/Pakeha respect, reciprocity, responsibility, obligations, sound relationships, honesty and decency. These are universal values that underpin the person I am and my adult behaviours. My early years were times of extensive new Maori/Pakeha learning through practice, laughter, explanation and osmotic absorption of demonstrated knowledge, upon which the brickwork of my adulthood was then mortared. Those years are significantly detailed in Chapter Three, to show how family and environmental shaping factors contributed to the strong foundations of my social construction and continuous identity reshaping.

My political connection to the classroom and teacher organisations from 1952 to 1991, detailed in Chapter Four, provided major learning recipient/responder stimuli for myself and those around me, as racism, sexism, feminism and social injustice impacted upon my consciousness. I came to understand throughout my life that I was categorised racially by appearance, and expected to behave according to the dominant culture of the Pakeha pre-determined Maori stereotype. In response, I honed and perfected multiple situational verbal, non-verbal and body language communication codes, as spontaneous survival strategies of resistance to that stereotyping. I believe those strategies also provided valuable social growth opportunities for Pakeha learning and acceptance of my Maori differences. A friend said to me, 'I know when you are being Maori and I know when you are being Pakeha. Don't ask me how I know. I just know.'315 Because my teaching appointments, from 1955 on, led to senior positions of power throughout my career, adult learning and the development of agency and power 'game-playing' were crucial elements during this life phase, as I refined my use of spoken English, body language, silences and laughter with others.

$315 \mathrm{~J}$. Cogle, personal communication, 1978. 
In a 1981 Auckland Star interview prior to my attending the UNESCO/WCOTP Conference in Morges, Switzerland, I was asked to comment upon bicultural education. I said then: 'If we were to start with the two major cultures in New Zealand and actually accept each other's differences instead of merely paying them lip service, we would have a firm foundation on which to build multiculturalism.'316 Well into my Third Age, some are still trying, and I still wonder if they are trying hard enough.

\section{BORDER CROSSING}

I have always operated comfortably in my Maori/Pakeha identity on the margins of two New Zealand cultures, in Homi Bhabha's third space, as an Irihapeti Ramsden border or frontier crosser, as Maori, as Pakeha and as blended Maori/Pakeha. I realise that has often been a problem for others, but it has been their problem, not mine. I own my problems. I do not own other people's problems.

\section{AGING}

The aging process during retirement, outlined in Chapter Five, brought new knowledge to use in exploring the social potentialities of my world, despite very major surgery for left and right hip replacements; consequential mobility impairment; cataract removals with right and left lens implants; risk of falling; Type 2 Diabetes, controlled by diet; and a major fracture of my left femur. General good health, excellent medical and nursing care and my positive attitude have ensured my text-book recovery.

My greatest satisfactions during my third age are in enjoying sharing the growth and development of my grandsons. My return to university study and my interests in Ngahina Trust have supported the maintenance of my nimble active mind. Having the ability to continue swimming pool exercise has contributed to my present good health, along with diet control of Type 2 Diabetes and low level osteoporosis

316 Taylor, K. M. (1981), Interview, Auckland Star, 27 May. 
medication. I regularly dine out to much laughter with my diminishing circle of family and friends. I still have a full current driving licence.

As I age, my Maori peers remind me of obligations and reciprocity towards our younger generations. Since I do not speak Te Reo Maori, Maori language, nor do I have a real depth of Maori knowledge, I can only encourage effort and admire accomplishment in Te Ao Maori, the Maori World, by those who have, and wish to retain, such skills. My strengths are my Pakeha skills.

Family successes are celebrated. I am proud of what my family have achieved. I pamper and indulge my mind with wonderful nuances of book language and my body with new fragrances and food. While many of my friends and family have passed on, like Nod Miller, 317 I am surrounded by my library of green memories, my world of books, mementoes and the learning it is my good fortune to physically and mentally continue experiencing, together with regular conversations with my dead. In the twilight of my years, inevitably I also approach my own demise. Death is not

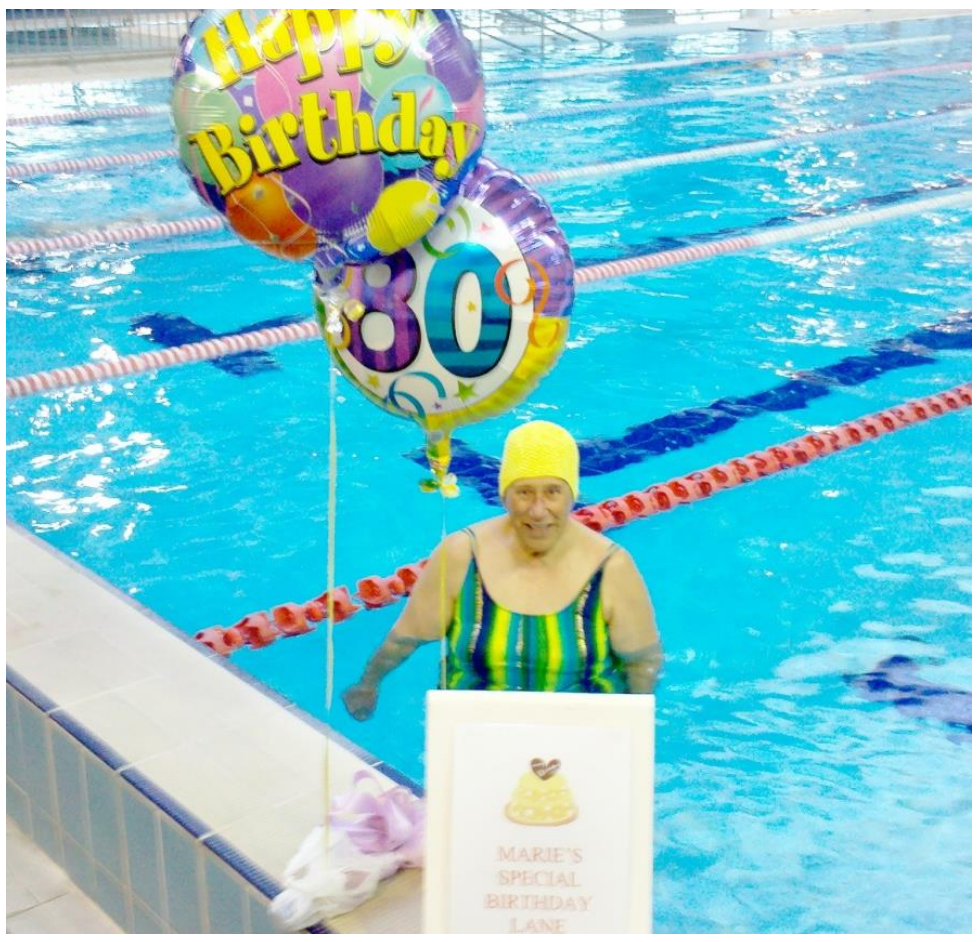
a subject that many people are comfortable discussing. I had hoped to leave my body to medical research. I am disappointed that is unlikely to happen now, because 'freshness' versus 'distance' becomes a major factor, as my family regularly voice their expectations that I downsize and return to my home in Waitara.

Figure 7. Kura Marie Teira Taylor, in 2012, aged 80, still swimming in the fast lane.

317 See Miller (1993), p. 40. 


\section{GLOSSARY - MAORI/ENGLISH}

aroha - love

ataahua - treasured

Aitanga - Maori women's theoretical research approach

Aotearoa - New Zealand

hapu - sub-tribe

Hinenuitepo - Goddess of Death

hui - meeting, gathering

iwi - tribe

kaanga wai - corn preserved in running water

kaupapa - strategy for action

Kaupapa Maori - Maori theories

kia ora - hello, thank you

kina - sea urchins

koutou - everyone

kowhaiwhai - decorative woven or painted panels on buildings

kui - female elder

kuia - female elders

mahi - work

Mahuika - Goddess of Fire

mana - power and authority

manaakitanga - caring, sharing, hospitality

Maori - Indigenous people of Aotearoa/New Zealand

Mana Wahine - Maori feminism; power and prestige of Maori women

Matauranga Maori - Maori knowledge

mauri - life force

Maori/Pakeha - blended identity of New Zealand Maori indigenous people and

Pakeha European people

moe moe - sleep

moko kauwe - woman's chin tattoo

mokopuna - grandchild

Ngaitahu Iwi - New Zealand South Island tribe

nga mate - those who have passed on

nga kupu - words

paake - female elder

Pakeha - New Zealand European people

paua - abalone

rangatiratanga - chiefly power

taewa - Maori potatoes

Tarara - Maori/Yugoslav identity

Taranaki Te Maunga Tapu - Taranaki the Sacred Mountain 
Te Atiawa Iwi Maori- Maori tribe from Taranaki, Wellington and Nelson areas Te Reo Maori - Maori Language

Te Ropu Wahine Maori Toko i te Ora - Maori Women's Welfare League

Tikanga Maori - Maori knowledge

tokotoko - carved walking stick

tupuna - ancestors

wahine - Maori woman

wairua - personal spiritual power

whakapapa - genealogy

whanau - immediate or extended familiy

whanui - grouping of all my extended families

whanaungatanga - relationship, kinship group

whangai - foster parents or an adopted child

wehi - awe, fear, formidable 


\section{REFERENCES}

\section{PublicATIONS, REPORTS, UnPUBLISHED WORK}

Taylor, K. M. (n.d.) Massey University Assignment on Learning Disabilities. Unpublished ms.

Taylor, K. M. (1976). Guide To The Conduct Of An Annual Meeting For Auckland Regional Council Maori Women's Welfare League, Auckland, NZ.

Taylor, K. M. (1980). Chairing A Staff Meeting - Some Practical Suggestions. Cornwall Park District Primary School, Auckland, NZ (revised 1988).

Taylor, K. M. (1979). South Auckland District Women's Tu Tangata Wananga. A paper evaluating the Wananga to the Department of Maori Affairs, Wellington, NZ.

Taylor, K. M. (1982). 'Maori Woman Teacher represents NZ at Switzerland Conference'. Tu Tangata Magazine, 4, February/March, p. 29.

Taylor, K. M. and McKenzie, J. L. (1983). 'Teaching About Major Issues Facing The World Today'. Unpublished ms, author's collection.

Taylor, K. M. with Paratene, F. M. L. (1989). Report Of Maori Women Teachers in Management 'Political Literacy' Course, author's collection.

Taylor, K. M. (1991). Kei Hea Nga Wahine Rangatira. Unpublished Research Affiliate Report, University of Auckland, Auckland, NZ.

Taylor, K. M. (1992). Te Reo Me Ona Tikanga Maori mo te Kura o Maungakiekie, Research Study To Set Up a Maori/English Bilingual Language Unit. Report to the Board of Trustees and Principal, Cornwall Park District School, Auckland.

Paratene, F. M. L. with Taylor, K. M. (1992). Maori Women And Technology, Research Report to Ministry of Education. Wellington: Ministry of Education.

Taylor, K. M. (1994). Conversations With Maori Women Educators / Nga Kupu Paake a nga Wahine Maori. Unpublished MPhil Thesis, Education, University of Auckland, Auckland, NZ.

Taylor, K. M. (1997). Report On Professional Development with Bilingual/Mainstream Teaching Team Te Puna Wananga. Auckland College of Education, Te Kura Akoranga o Tamaki Makaurau, Auckland, NZ.

Taylor, K. M. (2001a). A Perception of Trust Identities. Paper presented to Ngahina Trust Members, Paraparaumu, NZ.

Taylor, K. M. (2001b). Tomorrow. Paper presented to The 50th Jubilee Maori Women's Welfare League Conference, New Plymouth, NZ.

Taylor, K. M. (2001c). Autobiography As Research. Paper presented to Post-graduate Students, Auckland College of Education, Auckland, NZ. 
Taylor, K. M. and O’Driscoll, P. J. (2001d). Ngati Komako Submission - Proposed Change No 18 Kapiti Coast District Council District Plan. Paraparaumu, NZ.

Taylor, K. M. and O’Driscoll, P. J. (2001e). Submission - Review of the Public Works Act. Wellington, NZ.

Taylor, K. M. and Matthews, K. M. (2016). Korerotia Mo Nga Paake: Maori Women Educators Speak. In Panayotidis, E. L. and Stortz, P. (Eds), Women in Higher Education, 1850-1970: International Perspectives. New York and London: Routledge Taylor \& Francis Group, 228-250.

\section{SPEECHES}

Taylor, K. M. (1974a). Speech Of Farewell To Leonard McCarthy, General Manager, Auckland Education Board, followed by Presentation of Award of NZEI Associate, Auckland, NZ, 17 July.

Taylor, K. M. (1974b). With the Student Executive, Auckland Teachers' College, Auckland, NZ, November.

Taylor, K. M. (1974c). NZEI Members' Welcome To Auckland Branch Open Plan Seminar, Mt Roskill Primary School, Auckland, NZ, 23 October.

Taylor, K. M. (1974d). Vote of Thanks, Auckland Branch NZEI Human Development Seminar, Auckland, NZ.

Taylor, K. M. Closure Of Auckland NZEI World Education Conference, Auckland, NZ, 1975.

Taylor, K. M. (1980). Management In Educational Institutions - Maori, Panelist Address to Lopdell House Regional Inservice Course, Auckland, NZ, 11 November.

Taylor, K. M. (1981a). UNESCO/WCOTP Consultation, Switzerland: Address to Papatoetoe Branch NZEI, Papatoetoe, NZ, 3 December.

Taylor, K. M. (1981b). Speech on Relinquishing Office of Secretary Auckland Branch, NZEI, Auckland, NZ.

Taylor, K. M. (1981c). Response to Successful Nomination for Award of NZEI Fellow by Auckland Branch, NZEI, Auckland, NZ.

Taylor, K. M. (1981d). Presentation of Whakahuia on Behalf of NZEI, UNESCO/WCOTP Consultation on Peace and Human Rights, Morges, Switzerland, 29 June-3 July (reproduced in Connor, D. H. (1992).

Taylor, K. M. (1983). Response On Behalf of 1983 NZEI Fellows, Centennial Awards Dinner, Wellington Town Hall, Wellington, NZ, 12 May.

Taylor, K. M. Address And Proposal of School Toast, New Plymouth Girls' High School Centennial, New Plymouth Racecourse, New Plymouth, NZ, 1985.

Taylor, K. M. (1986). Address To Auckland NZEI Beginning Teachers Graduation Ceremony, Auckland College of Education, Auckland, NZ, December. 
Taylor, K. M. (1988). Autobiographical Moments, Response to launch of Sonja Davies (1987), Marching On, Working Women's Resource Centre, Auckland, NZ, 19 March.

\section{PRIMARY SOURCES}

Audit Office (2004). Maori Land Administration: Client Service Performance Of The Maori Land Court Unit And The Maori Trustee Report Of The Controller And Auditor General. Wellington: Audit Office.

Blundell, K. (2013). 'Coastlands owner remembered as a giant'. Dominion Post, 11 February. [Obituary quoting K. M. Taylor.] Available at http://www.stuff.co.nz/dominionpost/news/obituaries/8282181/Coastlands-owner-remembered-as-a-giant

Christchurch Teachers' College 1950 Students' Reunion. Booklet, Christchurch, Christchurch Teachers' College, 8-10 March 2000.

Coney, S. (Ed.) (1973). United Women's Convention 1973 Report, Auckland: UWC.

Cornwall Park School, 75th Jubilee 1921-1996. Jubilee booklet, Jubilee Organizing Committee, Auckland. Available at https://cornwallpark.school.nz/history/

Correspondence to K. M. Taylor:

25 February 1988, 6 October 1987, from Official Secretary. Government House, Auckland, re: acceptance by Paul Reeves as Patron for Maori Women in Management Group.

21 September 1987, from General Manager, Auckland Education Board, re: downgraded position, priority right of appointment.

10 June 1985, from Minister of Education, re: Appointment to Auckland Teachers College Council.

20 February 1985, Invitation from Alison Rumball, Chairman Centennial Planning Committee, to be Guest Speaker and Proposer of School Toast, New Plymouth Girls' High School Centennial, New Plymouth, New Zealand.

30 January 1981, from NZEI National Secretary to NZEI Advisory Committee on Maori Education Auckland, re: appreciation for the work of the committee.

20 August 1981, from NZEI National Secretary, re: recognition of representation at WCOTP/UNESCO Consultation, Morges, Switzerland.

26 January 1979, from I. P. Puketapu, re: Women's Tu Tangata Conference, Wellington, New Zealand.

Frost, L. (n.d.) Skelton Family History. Unpublished manuscript, in author's possession.

Hamiora, A. M. (1987). Clydemore School: Te Whanau O Tumanako 1984-1987. Otara, Aotearoa/NZ.

Mana Magazine, 59, August-September 2004, pp. 8-10. 
Maori Economic Development Summit Conference, Conference Background Papers, October, Wellington, 1984.

Ministry for Culture and Heritage (2017). 'End of free school milk'. https://nzhistory.govt.nz/end-of-free-school-milk Updated 12 April.

Morrison, A., Brown, K. and Orbell, M. (1983). Articles on Report On Waitangi Tribunal Claim Relating To Motonui And Te Whiti. Tu Tangata Maori News Magazine, 13, June/July. Mount Egmont Vesting Act 1978. Wellington: Government Printer.

Maori Women's Welfare League (2002). Constitution. Wellington: MWWL.

Maori Women's Welfare League Auckland (2002). Tamaki Makaurau Maori Women's Welfare League Regional History (circulated to Branches).

New Plymouth Girls' High School Register, 1941-1955.

New Zealand Department of Education, Personal file, 1952-1954.

New Zealand Education Gazette, Department of Education, Wellington, NZ, 1 February-15 December, 1939.

NZEI, Review of NZEI Maori Education Policy Formulated In 1967 And 1971, Discussion Document to NZEI Branches (n.d.).

NZEI (1967). Report and Recommendations on Maori Education. Wellington: NZEI.

NZEI, Auckland Centennial 1875-1975 Auckland Branch 99th Annual Report \& Balance Sheet, March 1975.

NZEI Advisory Committee on Maori Education, Record of Initial Meeting dated 27 November 1979; Minutes of Meetings dated 19 December 1979; 8 March 1980; 14 June 1980; 16 August 1980.

NZEI (1976). Education: A Selection of Papers from Auckland Centennial World Education Conference, 1975. Auckland: Abco Press Ltd.

NZEI Advisory Committee on Maori Education (1980). Interim Report To NZEI National Executive.

NZEI (1981). 'Peace And Human Rights Consultation - NZEI Representative Presides.' Nat Ed Newsletter 8(13), 9 September.

NZEI (1982). Te Tatai Hono: Report and Recommendations on Maori Education. Wellington: NZEI

Ruawai Schools 75th Jubilee 1929-2004, Reunion Committtee, Ruawai, Northland, New Zealand.

Taranaki Maori Trust Board (1936). Hui Whakamahara Ki A Maui Pomare, Opening Of The Waitara Carved House. Taranaki Maori Trust Board.

Teacher Registration Board (1991). The Registration Of Teachers In New Zealand (2 ${ }^{\text {nd }}$ edn). Wellington: TRB. 
Teacher Registration Board (2000). Te Rehita: The Register. Newsletter from the Teacher Registration Board, Wellington, December.

Te Whanau $O$ Waipereira (1991). Te Whanau: A Celebration Of Te Whanau O Waipereira, Te Whanau 0 Waipereira, Henderson, NZ.

UNESCO/World Confederation of the Organisations of the Teaching Profession, Consultation Papers, 16 June 1981:

'Methods Of Approach To Education For Peace, International Understanding And Respect For Human Rights' - Yvonne Vella, Malta.

'Education for Peace' - Dr Steven Derksen, Netherlands.

'Evaluation Of Experiences And Methods Of Associated Schools In The African Region South Of The Sahara' - Abiboulaye Sy, Senegal.

'Education For Peace, International Understanding And Relating To Human Rights In The German Democratic Republic' - Dr R. Pfeifer, Erfurt, GDR.

'Survey Of Various Methodological Approaches To Contents Of Education In Spirit of Peace And Disarmament' - Yuri K Babansky, Russia.

UNESCO/WCOTP Consultation Education for Peace and Respect For Human Rights: summary of discussion on an inventory and evaluation of experiences 1981 - Robert Harris.

WCOTP/CMOPE, Assembly of Delegates, Working Papers, Regina, Canada, 1-7 August, 1986.

Waitangi Tribunal (1996). WAI 143: The Taranaki Report, Kaupapa Tuatahi. Wellington: GP Publications.

Waitangi Tribunal (2003). WAI 145: Te Whanganui A Tara Me Ona Takiwa, Report On The Wellington District. Wellington: Legislation Direct.

Waitara Central School Jubilee Committee (1975). Waitara Central School Centenary, 18751975: Souvenir Booklet $16^{\text {th }}, 17^{\text {th }}$, 18 ${ }^{\text {th }}$ May, Jubilee Committee, Waitara.

Walker, R. (1974). He Kaupapa Mo Nga Komiti A Iwi O Te Motu: Committee Procedure for Maori Meetings. Centre for Continuing Education, University of Auckland, Auckland, NZ.

Wattembach, R. (n.d.) Nga Tangata Tiaki Nga Kahurangi O Maoritanga: The Maori Waitara's Early Settlers. Annotated series of articles for The Times-Record, Waitara, NZ.

Westra, A. (1964). Washday at the Pa. Wellington: School Publications Branch, Department of Education. (Withdrawn; republished (with additional photographs), Christchurch: Caxton Press, 1964.)

Whitcombe \& Tombs (1950-59). Whitcombe's Progressive Readers (revised edn.). Christchurch: Whitcombe \& Tombs Ltd

Willan, R. (2002). Waitara Endowments Interim Report (Draft), New Plymouth, NZ. 
Women's Advisory Committee on Education (1988). A National Policy for the Education of Girls And Women in New Zealand. Wellington: Ministry of Education.

\section{Published SOURCES AND UnPublished THESES AND PAPERS}

Alcorn, N. (2015). Between the Profession and the State: A history of the New Zealand Teachers Council. Wellington: NZCER Press.

Alexander, A. C. (1979). Waitara: A Record Past and Present. New Plymouth, NZ: Taranaki Newspapers for New Plymouth Borough Council.

Anderson, A., et al. (2014). Tangata Whenua: An Illustrated History. Wellington: Bridget Williams Books.

Anonymous (n.d.). Our Nation's Story, A Course of British History, Britain's Primary History Series. London, Melbourne and Sydney: Whitcombe \& Tombs Ltd, NZ.

Anonymous (1927). The Wonder Book of Taranaki. New Plymouth: Thomas Avery \& Sons Ltd.

Ashbridge, G. (1965). Teachers' Legal And Service Handbook (7th edn.) Wellington: NZEI.

Awatere Huata, D. (1996). My Journey. Auckland: Seaview Press.

Barlow, P. (1996). 'Teacher Licensing: Compulsory or Voluntary.' Paper prepared for the International Bureau of Education $45^{\text {th }}$ International Conference on Education, 'Strengthening the Role of Teachers in a Changing World', Geneva, Switzerland, 30 September-5 October.

Beeby, C. E. (1992). Biography Of An Idea: Beeby On Education. Wellington: New Zealand Council for Educational Research.

Beyer, G. (1999). Change for The Better. Auckland: Random House NZ.

Belich, J. (1996). Making Peoples: A History of the New Zealanders. Auckland: Penguin Books NZ.

Bell, K. (1976). Education in Change. In NZEI, Education, A Selection of Papers from Auckland World Education Conference 1975. Auckland: Abco Press Ltd.

Bhabha, H. (1998). The Third Space: Interview with Homi Bhabha. In Rutherford, J. (Ed.), Identity: Community, Culture, Difference. London: Lawrence and Wishart, pp. 207-221.

Bioletti, H. (1989). The Yanks are coming: The American invasion of New Zealand, 1942-1944. Auckland: Century Hutchinson Ltd.

Bird, D. and Haskell, D. (1992). Whose Place? A Study Of Sally Morgan's My Place. Sydney: Angus \& Robertson.

Bird, L. and Drewery, W. (2003). Human Development In Aotearoa: A Journey Through Life. Auckland: McGraw-Hill NZ. 
Brockmeier, J. and Carbaugh, D. (Eds), (2001). Narrative and Identity Studies in Autobiography: Self and Culture, Vol. 1. Amsterdam, PHL: John Benjamin.

Brown, A. (Ed.) (1994). Mana Wahine: Women Who Show the Way. Auckland: Reed Publishing

Bullough Jr, R. V. and Pinnegar, S. (2001). Guidelines For Quality In Autobiographical Forms Of Self-study Research. Educational Researcher 30(3), 13-21.

Burton, D. (1982). Two Hundred Years of New Zealand Food and Cookery. Auckland: Bateman..

Byron, I. (2002). Nga Perehitini: The Presidents Of The Maori Women's Welfare League 1951-2001. Auckland: Maori Women's Development Inc.

Carter, P.L. (2005). Keepin' It Real: School Success Beyond Black and White. New York: Oxford University Press.

Carter, P.L. (2010). Race and Cultural Flexibility among Students in Different Multiracial Schools. Teachers College Record, 112(6), 1529-1574. http://dx.doi.org/

Chapman, L. (2003). In a Strange Garden: The Life and Times of Truby King. Auckland: Penguin Books NZ.

Cole Catley, C. (1985). Springboard For Women: New Plymouth Girls' High School 18851985. Queen Charlotte Sound, NZ: Cape Catley.

Coney, S. (Ed.) (1993). Standing in the Sunshine: A History of New Zealand Women Since They Won the Vote. Auckland: Penguin Books NZ.

Connor, D.H. (1992). A Life History of Kura Marie Taylor. Unpublished research report, including nine taped interviews, Post-graduate Diploma, Women's Studies, Massey University, Palmerston North, NZ.

Connor, D. H. (1994). Images of My Tupuna: A Family Portrait Re-focused. Te Pua, 3(1), 7-9. http://hdl.handle.net/2292/33700

Connor, D. H. (2000). Reclamation of Cultural Identity for Maori Women: a Response to 'Prisonisation'. In Jones, A., Herder, P. and Suaalii, T. (Eds), Bitter Sweet: Indigenous Women In The Pacific. Dunedin: University of Otago Press, pp. 125-135.

Connor, D. H. (2006). Writing Ourselves 'Home': Biographical Texts: A Method For Contextualising The Lives Of Wahine Maori: Locating The Story Of Betty Wark. Unpublished PhD Thesis, University of Auckland, Auckland, NZ. https://researchspace.auckland.ac.nz/handle/2292/53

Connor, D. H. (2014). Maori mothering: Repression, resistance and renaissance. In Anderson, K., and Lavell-Harvard, D. (Eds.), Mothers of the nations: Indigenous mothering as global resistance, reclaiming and recovery. Bradford, Ontario: Demeter Press.

Conway, J. K. (Ed.) (1994). Written By Herself: Autobiographies of American Women. New York and London: Vintage Books. 
Conway, J. K. (Ed.) (1998). Written By Herself Volume II. New York and London: Vintage Books.

Conway, J. K. (1998). When Memory Speaks: Reflections On Autobiography. New York: Alfred A Knopf.

Cowan, J. (1930). Legends of the Maori. Wellington: Harry H. Tombs Ltd.

Davies, S. (1984, 1997). Bread and Roses. Auckland: Random House NZ;

Davies, S. (1997). Marching On. Auckland: Random House NZ.

Dewes, Te K. (1977). The Case For Oral Arts. In King, M. (Ed.), Te Ao Hurihuri, revised edn. Wellington: Hicks Smith, p. 47.

Douglas, K. (2001). Living Life Out Loud: 22 Inspiring New Zealand Women Share Their Wisdom. Auckland: Harper Collins NZ.

Douglas, K. and McGregor, K. (2000). Power Games. Auckland: Penguin Books NZ.

Durie, M. (2001). Launching Maori Futures. Wellington: Huia Publications.

Durie, M. (2005). Ngā Tai Matatu. Melbourne: Oxford University Press.

Durie, M. (2005). Ngā Tai Matatū: Tides of Mãori Endurance. Melbourne: Oxford University Press.

Edwards, M. (1990). Mihipeka: Early Years. Auckland: Penguin Books NZ.

Edwards, M. (1992). Mihipeka: Time of Turmoil Nga Wa Raruraru. Auckland: Penguin Books NZ.

Edwards, M. (2002). Mihipeka: Call Of An Elder, Karanga A Te Kuia. Auckland: Steele Roberts.

Evans, A. B. (n.d.). Bible Pictures and Stories, Vol. One: Easy Steps in the Bible Story From Creation to Joseph; Vol. Two: The Children's Friend Pictures and Stories of Jesus; Vol. Three: Men of Might From Moses to Samuel; Vol. Four: Stories of the Kings From David to Christ. Warburton, VIC.: Signs Publishing Company.

Evans, R. (1994). Maori Women as Agents of Change. Te Pua 3(1) 31-37.

Fletcher, W. J. (2001). A Sense of Community: The Christchurch College of Education 18772000. Christchurch: Christchurch College of Education

Frame, J. (1982). To the Is-land. New York: George Braziller.

Frost, L. (n.d.) Skelton Family History. Unpublished manuscript, in author's possession.

Galman, K. (1992), I Dreamed of Africa. London: Penguin Books

Gibson, K. (1999). Maori Women and Dual Ethnicity: Investigating Pathways. Unpublished MA Thesis, Department of Psychology, Waikato University, Hamilton, NZ. 
Green, A. and Hutching, M. (Eds) (2004). Remembering: Writing Oral History. Auckland: Auckland University Press.

Griffiths, M. (1995). Feminisms And The Self: The Web of Identity. London and New York: Routledge.

Harris, R. (1981). UNESCO/WCOTP Consultation on Education For Peace and Respect For Human Rights: Summary of discussions on an inventory and evaluation of experiences. Geneva: UNESCO/WCOTP.

Hamiora, A. M. (2004). Aku Waiata Mo Nga Tamariki, Mokopuna 1980-1990. Unpublished MEd Thesis, University of Auckland, Auckland, NZ.

Henare, D. (1994). Interview in Brown, A. (Ed.), Mana Wahine: Women Who Show the Way. Auckland: Reed Publishing.

Highfield, C. (1999). Kura Te Waru Rewiri: A Maori Woman Artist. Wellington: Gilt Edge Publishing.

Hill, R. S. (2009). Maori and the State: Crown-Maori Relations in New Zealand/Aotearoa, 1950-2000. Wellington: Victoria University Press.

Hohaia, Te M., O'Brien, G. and Strongman, L. (Eds) (2001). Parihaka: The Art Of Passive Resistance. Wellington: Victoria University Press/Parihaka Pā Trustees.

Hunn, J. K. (1961). Report on Department of Maori Affairs. Wellington: Government Printer. Ihimaera, W. (Ed). (1992). Te Ao Marama 1, Contemporary Maori Writing, Auckland: Reed Books.

Ihimaera, W. (Ed). (1993). Te Ao Marama 2, Regaining Aotearoa: Maori Writers Speak Out. Auckland: Reed Books.

Ihimaera, W. (Ed). (1998). Growing Up Maori. Auckland: Tandem Press.

Irwin, K. (1993). Maori Feminism. In Ihimaera, W. (Ed.), Te Ao Marama 2, Regaining Aotearoa: Maori Writers Speak Out. Auckland: Reed Publishing, pp. 299-304.

Irwin, K. and Ramsden, I. (Eds) (1995). Toi Wahine: The Worlds Of Maori Women. Auckland: Penguin Books NZ.

Jenkins, K. and Morris Matthews, K. (1995). Hukarere and the Politics of Maori Girls' Schooling. Palmerston North: Dunmore Press.

Jenkins, K. (2000). Haere Tahi Täua: An Account of Aitanga in Maori Struggle for Schooling. Unpublished PhD Thesis, Education, University of Auckland.

Johnson, P. and Pihama, L. (1995). What Counts As Difference And What Differences Count: Gender, Race And The Politics Of Difference. In Irwin, K. and Ramsden, I. (Eds), Toi Wahine: The Worlds Of Maori Women. Auckland: Penguin Books NZ, pp. 75-86.

King, M. (1981). New Zealanders at War. Auckland: Heinemann. 
King, M. (1983). Whina: A Biography of Whina Cooper. Aucklan: Hodder \& Stoughton.

King, M. (2004). Being Pakeha Now: Reflections and Recollections of a White Native. Auckland: Penguin Books NZ.

Kohere, R. T. (1951). The Autobiography of a Maori. Wellington: A. H. \& A. W. Reed.

Kohler, E. (2000), Lost Years. Glebe, NSW: Book House at Wild \& Woolley.

Krall, F. R. (1988). From The Inside Out - Personal History As Educational Research. Educational Theory 38 (4), 467-479.

Kuzwayo, E. (1985). Call Me Woman. London: The Women's Press.

Lashlie, C. (2002). Journey to Prison: Who Goes and Why. Auckland: Harper Collins NZ.

Maclean, R. (1992). Teacher's career and promotion patterns: a sociological analysis. Washing DC: Falmer.

Mansell, B. (2007). Ngahina Trust: A Celebration 2007. New Plymouth: TNL \& Graphics for Ngahina Trust.

May, H. (2011). 'I am five and I go to school': Early Years Schooling in New Zealand, 19002010. Dunedin: Otago University Press.

McGavin, T.A. (1976). A Century of Railways in Taranaki. Wellington: New Zealand Railway and Locomotive Society Inc.

McGibbon, I. (2003). New Zealand And The Second World War, The People, The Battles, And The Legacy. Auckland: Hodder Moa Beckett.

McGregor, M. (1975). Petticoat Pioneers: North Island Women of the Colonial Era, Book Two. Wellington: A. H. and A. W. Reed.

McLeod, V. (1991). Memories of Ruawai, Tokatoka \& Rehia. [Dargaville, NZ]: North Auckland Times.

Mead, A. Maori Leadership. Te Pua 3(1), 11-20.

Mead, L. T. Te R. (1996). Nga Aho O Te Kakahu Matauranga: The Multiple Layers of Struggle by Maori in Education. Unpublished PhD Thesis, University of Auckland, Auckland.

Meredith, P. (1998). Hybridity in the Third Space: Rethinking Bi-cultural Politics in Aotearoa/New Zealand. Paper presented to Te Oru Rangahau Maori Research and Development Conference, 7-9 July, Massey University, Palmerston North, NZ.

Metge, J. (1976). The Maoris of New Zealand: Rautahi. London: Routledge and Kegan Paul. Metge, J. (2001). Korero Tahi: Talking Together. Auckland: Auckland University Press.

Metge, J. (2010). Tuamaka: The Challenge of Difference in Aotearoa New Zealand. Auckland: Auckland University Press. 
Metge, J. and Kinloch, P. (1984). Talking Past Each Other. Wellington: Victoria University Press.

Mikaere, A. (1994). Maori Women: Caught in the Contradictions of a Colonised Reality. Waikato Law Review, 2: 125-149. http://2.waikatao.ac.nz/law/wlr/1994/article6-mikaere.html

Middleton, S. (Ed.) (1988). Women And Education In Aotearoa. Wellington: Allen \& Unwin/Port Nicholson Press.

Middleton, S. (2001). Educating Researchers: New Zealand Education PhDs 1948-1998. 'State-of-the-Art' Monograph No. 7, July. Wellington: New Zealand Association For Research in Education.

Middleton, S. and Jones, A. (Eds) (1992). Women And Education In Aotearoa 2. Wellington: Bridget Williams Books.

Miller, N. (1993). Personal Experience, Adult Learning and Social Research. Publications Thesis Series, Centre for Research in Adult Education for Human Development, University of South Australia.

Mitchell, H. and J. (2004). Te Tau Ihu O Te Waka: A History of Maori of Nelson and Marlborough, Volume 1: Te Tangata Me Te Whenua, The People And The Land. Wellington: Huia Publishers with Wakatu Incorporation.

Moir, M. (1994). Images of Maori Women: Mataahua Wahine. Auckland: Tandem Press.

Monteith, M. (1986). Women's Writing: A Challenge To Theory. New York: St Martin's Press.

Montgomerie, D. (2001). The Women's War: New Zealand Women 1939-45. Auckland: Auckland University Press.

Moriarty, J. with McHugh, E. (2000). Saltwater Fella. Melbourne: Viking Penguin Books.

Morris Matthews, K. (2008). In Their Own Right: Women and Higher Education in New Zealand Before 1945. Wellington: NZCER Press.

Murchie, E. (1984). Rapuora: Health and Maori Women. Wellington: MWWL. Myers, V. (1986). Head and Shoulders: Successful New Zealand Women talk to Virginia Myers. Auckland: Penguin Books NZ, p. 234.

Ngata, A. and Jones, P. Te Hurunui (1972). Nga Moteatea. Wellington: A. H. \& A. W. Reed for the Polynesian Society.

O’Regan, H. Ko Tahu, Ko Au: Kai Tahu Tribal Identity. Christchurch: Horomaka Publishing.

Paki-Titi, R. (1992). Rangimārie: Recollections of Her Life. Wellington: Huia Publishers.

Pease, A. and B. (204). The Definitive Book Of Body Language. How To Read Others' Thoughts By Their Gestures. Buderin, NSW: Pease International.

Phillips, J. (1996). A Man's Country? The Image of the Pakeha Male. Auckland: Penguin Books NZ. 
Pihama, L. (2003). Interview in Smith, H. (Ed.), Taiawhio: Conversations With Contemporary Maori Artists, Wellington: Te Papa Press, p. 106.

Pohatu, T. (2003). Āta: Growing Respectful Relationships. Paper presented to Maori and Indigenous PhD Seminar, University of Auckland, Auckland, NZ.

Pomare, Hon. Sir M. (1934). Legends Of The Maori Volume II. Wellington: Harry H. Tombs Ltd.

Port, W. (1993). Assimilation: Mission Accomplished. Te Pua, 2 (1), 8-9.

Pountney, C. (2000). Learning Our Living: A Teaching Autobiography. Auckland: Cape Catley.

Price, H. (1992). School Books Published in New Zealand to 1960. Palmerston North: Dunmore Press.

Pugsley, C. (2006). Te Hokowhitu A Tu. The Maori Pioneer Battalion in the First World War. Auckland: Reed Publishing.

Puketapu, K. (1982). Reform from Within. Wellington: Department of Maori Affairs.

Quin, M. (2004). Kidnapped In Yemen. Auckland: Random House NZ.

Ramsden, I. (1993). Borders and Frontiers. In Ihimaera, W. (Ed.), .), Te Ao Marama 2, Regaining Aotearoa: Maori Writers Speak Out. Auckland: Reed Publishing.

Rangihau, J. (1977). Being Maori. In King, M. (Ed), Te Ao Hurihuri: The World Moves On. Auckland: Hicks Smith \& Sons, pp. 165-175.

Redfield Jamison, K. (1995). An Unquiet Mind. New York: Alfred A Knopf.

Rennie, F. (1993). Maungakiekie and a Maori Process. Unpublished seminar presentation, Albany Campus, Massey University, Auckland, NZ.

Rei, T., McDonald, G. and Te Awekotuku, N. (1993). Nga Ropu Wahine Maori: Maori Women's Organisations. In Else, A. (Ed.), Women Together, Nga Ropu Wahine o te Motu: A History of Women's Organisations in New Zealand. Wellington: Historical Branch, Department of Internal Affairs and Daphne Brasell Associates, pp. 3-17.

Richardson, L. (1997). Fields of Play. New Brunswick, NJ: Rutgers University Press. Riseborough, H. (2002). Days of Darkness (revised edn.). Auckland: Allen and Unwin/Penguin Books NZ.

Ritchie, J. (1970). The Maori Background. In Ewing, J. and Shallcrass, J. (Eds), Introduction to Maori Education: Selected Readings, Wellington: New Zealand University Press/Price Milburn and Co.

Roskruge, N. (1999). Taewa Maori: Research Report. Palmerston North: Massey University.

Roth, B. and Hammond, J. (1981). Toil And Trouble: The Struggle for a Better Life In New Zealand. Auckland: Methuen Publications (New Zealand) Ltd.

Ruawai District High School 75th Jubilee 1929-2004, Jubilee booklet. 
Salmond, A. (1976). Amiria: The Life Story of a Maori Woman. Wellington: A.H. and A.W. Reed.

Scott, D. (1976). Ask That Mountain: The Story Of Parihaka - Taranaki Wars. Auckland: Heinemann/Southern Cross.

Shepard, D. (2000). Reframing Women: A History Of New Zealand Film. Auckland: HarperCollins.

Shepard, D. (2009). Her Life's Work: Conversations with Five New Zealand Women. Auckland: Auckland University Press.

Sikes, P. (2010). The Ethics of Writing Life Histories and Narratives in Educational Research. In Bathmaker, A. and Harnett, P. (Eds), Exploring Learning, Identity and Power Through Life History and Narrative Research. London: Routledge/Falmer, pp. 11 -24.

Simmonds, E. J. (1983). NZEI 100: An Account Of The New Zealand Educational Institute 1883-1893. Wellington: NZEI.

Simon, J. (Ed.) (1998). Ngā Kura Māori: The Native Schools System 1867-1969. Auckland: Auckland University Press.

Simpson, M. (Ed.) (1992). He Rourou Iti: Selected Speeches Of Te Arikinui Dame Te Atairangikaahu. Wellington: Miria Simpson and Daphne Brasell Associates Press.

Smith, G. H. (1997). The Development Of Kaupapa Maori: Theory And Praxis. Unpublished PhD thesis, University of Auckland, Auckland, NZ.

Smith, L. T. (2012). Decolonising Methodologies: Research and Indigenous Peoples (revised edn.). London and New York: Zed Books, p. 136.

Smith, S. (1993). Subjectivity, Identity and the Body: Women's Autobiographical Practices in the Twentieth Century. Bloomington, IN: Indiana University Press.

Smith, S. (1994). Identity's Body. In Ashley, K., Gilmore, L., and Peters, G. (Eds)., Autobiography and Postmodernism. Boston: University of Massachusetts Press, pp. 266267.

Sykes, Roberta, 1993, Murawina, Australian Women of High Achievement, Doubleday, Australia, 1993).

Stanley, L. (1992). The Autobiographical I: The Theory and Practice of Feminist Auto/biography. Manchester and New York: Manchester University Press.

Stewart, D. (1991). Springtime In Taranaki: An Autobiography Of Youth. Auckland: Harper Collins.

Stuart, I. (2001). In The Line Of Fire: New Zealanders Tell Their Wartime Stories. Auckland: Reed Books.

Sykes, R. (1993). Murawina, Australian Women of High Achievement. Lane Cove, NSW: Doubleday.

Sykes, R. (1997). Snake Cradle: Autobiography Of A Black Woman. Sydney: Allen \& Unwin. 
Sykes, R. (1998). Snake Dancing: Autobiography Of A Black Woman. Sydney: Allen \& Unwin.

Sykes, R. (2000). Snake Circle: Autobiography Of A Black Woman. Sydney: Allen \& Unwin.

Szaszy, M., Rogers, A., and Simpson, M., Early stories from founding members of the Maori Women's Welfare League, Te timatanga tatau tatau, Te Ropu Wahine Maori Toko i te Ora. Wellington: Maori Women's Welfare League and Bridget Williams Books.

Tamihere, J. with Bain, H. (2004). Black \& White. Auckland: Reed Books.

Teariki, C. and Spoonley, P. with Tomoana, N. (1992). Te Whakapakari Te Mana Tangata. The Politics and Process Of Research For Maori, Department of Sociology. Palmerston North, NZ: Massey University.

Te Rangihiroa/Buck, P. (1940). The Coming of the Maori. Christchurch: Whitcombe and Tombs for The Maori Purposes Fund Board.

Te Wharemaru, H. with Duffie, K. M. (1997). Heeni: A Tainui Elder Remembers. Auckland: HarperCollins.

Thompson, M. (Ed). (1999). On Active Service: 5/77 O R Gatman 2 NZEF September 1939November 1941. Auckland: Addison Wesley Longman NZ.

Thompson, M. (1980). All My Lives. Christchurch: Whitcoulls.

Thornton, A. (1985). Two Features of Oral Style in Maori Narrative. The Journal of The Polynesian Society 94(2), June, 149-176.

Turner, B. (2002). Somebodies And Nobodies: Growing Up In An Extraordinary Sporting Family. Auckland: Vintage Books.

Tippins, M. (1993). Maraea Tippins. In Szaszy, M., Rogers, A., and Simpson, M., Early stories from founding members of the Maori Women's Welfare League, Te timatanga tatau tatau, Te Ropu Wahine Maori Toko i te Ora. Wellington: Maori Women's Welfare League and Bridget Williams Books.

Unterhalter, E. (2000). Remembering and Forgetting: Constructions of Education Gender Reform in Autobiography and Policy Texts of the South African Transition. In Goodman, J. and Martin, J. (Eds), Breaking Boundaries: Gender, Politics, And The Experience of Education, History of Education Special Issue, Journal of the History of Education Society 29 (5), pp. 457-472.

Walker, R. (1996). Nga Pepa a Ranginui. Auckland: Penguin Books NZ.

Walker, R. (2001), He Tupua: The Life and Times of Sir Apirana Ngata. Auckland: Viking.

Ward, J. P. (1888). Wanderings with the Maori Prophets, Te Whiti \& Tohu: Being Reminiscences of a Twelve Months' Companionship with Them, From Their Arrival in Christchurch in April 1882, Until Their Return to Parihaka in March 1888. Nelson: Bond, Finney, \& Co. 
Watkins, J. H. (Ed.) (1998). Southern Selves: From Mark Twain and Eudora Welty to Maya Angelou and Kaye Gibbons, A Collection of Autobiographical Writing. New York: Vintage Books.

Webber, M. (2008). Walking the Space Between: Identity and Maori/Pakeha. Wellington: New Zealand Council for Educational Research.

Webster, P. (1979). Rua and The Maori Millennium. Wellington: Price Milburn for Victoria University Press.

Weedon, C. (1999). Feminism, Theory, And The Politics Of Difference. Oxford: Blackwell.

Weeks, J. (1990). The Value of Difference. In Rutherford, J. (Ed.), Identity, Community, Culture, Difference. London: Lawrence and Wishart,, pp. 88-100.

Weiler, K. (1988). Women Teaching For Change: Gender, Class And Power. South Hadley, Mass: Bergin and Harvey.

Weiler, K. and Middleton, S. (Eds). (1999). Telling Women's Lives, Narrative Inquiries In The History Of Women's Education. Buckingham, PHL.: Open University Press.

Wells, B. (1878). The History Of Taranaki. New Plymouth, NZ: Edmonson \& Avery.

Wells, P. (2001). Long Loop Home: A Memoir. Auckland: Vintage Books NZ.

Whelehan, I. (1995). Modern Feminist Thought From The Second Wave To 'Post-Feminism'. Edinburgh: Edinburgh University Press.

White, R. (1991). The Middle Ground: Indians, Empires, and Republics in the Great Lakes Region, 1650-1815. Cambridge, UK: Cambridge University Press.

Williams, J. A. (2012). The Personal is Political: Thinking Through the Clinton/Lewinsky/Starr Affair. http://faculty.uml.edu/sgallagher/Williams.htm, 26 March.

Williams, R. (1989). Keywords (revised and expanded edn.). London: Flamingo Press.

Willis, P. (2002). Inviting Learning. Leicester, UK: NIACE.

Wolfe, R. (2001). In My Day .... Looking at New Zealand's Past, Auckland: Cumulus, Whitcoulls Ltd.

Wong, H.D. (1992). Sending My Heart Back Across The Years. Oxford: Oxford University Press.

Wordsworth, J. (1979). Leading Ladies: Twenty-Three Outstanding Women. Wellington: A. H. \& A. W. Reed.

Wortham, S. (2001). Narratives in Action: A Strategy for Research and Analysis. New York: Teachers College Press. 